\title{
A TRANSIENT NUMERICAL SIMULATION OF PERCHED GROUND-WATER FLOW AT THE TEST REACTOR AREA, IDAHO NATIONAL IEOEIVEE ENGINEERING AND ENVIRONMENTAL LABORATORY, IDAHO, 1952-94 NOY 012000 \\ OSTI
}

By Brennon R. Orr

\section{U.S. GEOLOGICAL SURVEY}

Water-Resources Investigations Report 99-4277

Prepared in cooperation with the

U.S. DEPARTMENT OF ENERGY

Idaho Falls, Idaho

November 1999 


\section{U.S. DEPARTMENT OF THE INTERIOR \\ BRUCE BABBITT, Secretary}

U.S. GEOLOGICAL SURVEY

Charles G. Groat, Director

Any use of trade, product, or firm names is for descriptive purposes

only and does not imply endorsement by the U.S. Government.

For additional information write to:

Project Office

U.S. Geological Survey

INEEL, MS 1160

P.O. Box 2230

Idaho Falls, ID 83403-2230
Copies of this report can be purchased from:

U.S. Geological Survey

Information Services

Box 25286

Federal Center

Denver, CO 80225 


\section{DISCLAIMER}

This report was prepared as an account of work sponsored by an agency of the United States Government. Neither the United States Government nor any agency thereof, nor any of their employees, make any warranty, express or implied, or assumes any legal liability or responsibility for the accuracy, completeness, or usefulness of any information, apparatus, product, or process disclosed, or represents that its use would not infringe privately owned rights. Reference herein to any specific commercial product, process, or service by trade name, trademark, manufacturer, or otherwise does not necessarily constitute or imply its endorsement, recommendation, or favoring by the United States Government or any agency thereof. The views and opinions of authors expressed herein do not necessarily state or reflect those of the United States Government or any agency thereof. 


\section{DISCLAIMER}

Portions of this document may be illegible in electronic image products. Images are produced from the best available original document. 


\section{CONTENTS}

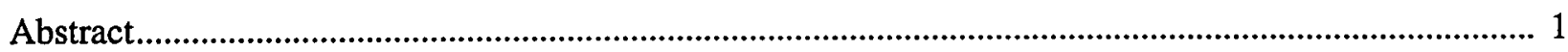

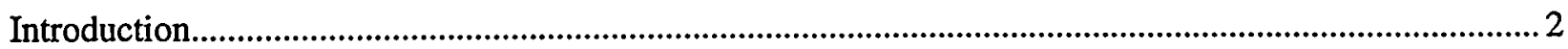

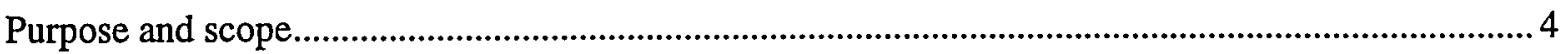

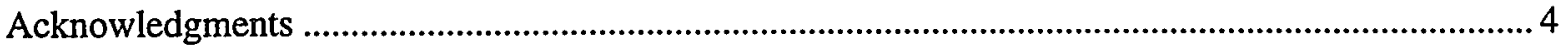

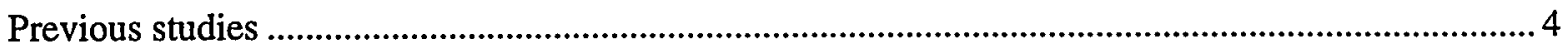

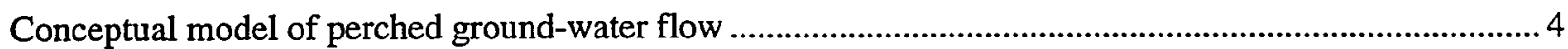

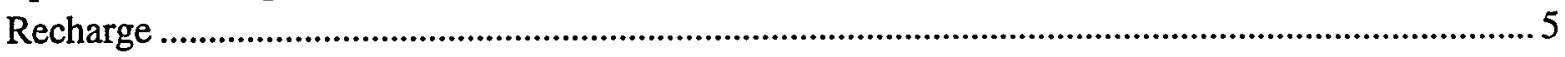

Recharge from wastewater disposal at the Test Reactor Area.......................................................5

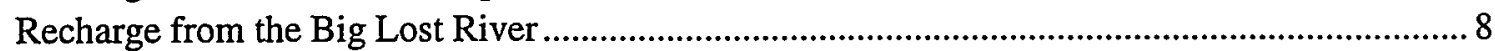

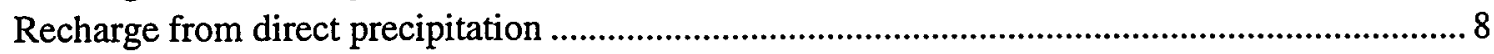

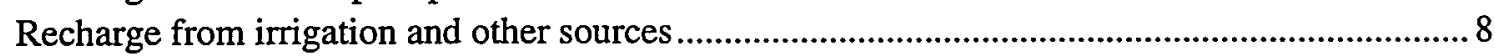

Geohydrologic Framework .............................................................................................................. 10

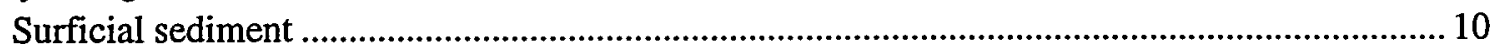

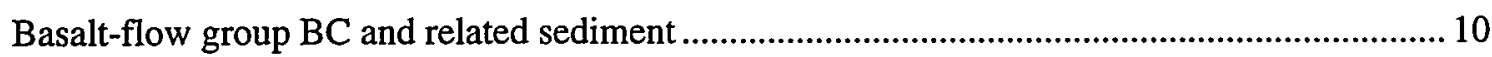

Basalt-flow group DE1 and related sediment ....................................................................... 10

Interbed unit associated with basalt-flow groups DE2, DE3, and DE3-4(W) .............................. 12

Basalt-flow groups and related sediment underlying perched ground water at the

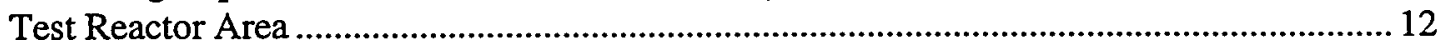

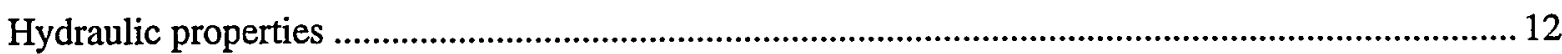

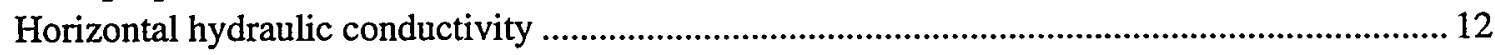

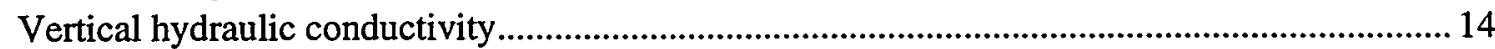

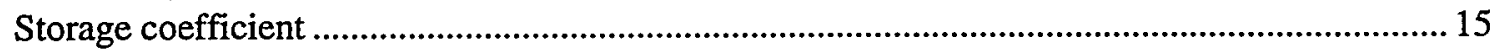

Hydraulic response of perched ground-water zones to changes in hydrologic conditions.................. 15

The effect of wastewater disposal on water levels in perched ground-water zones ..................... 17

The effect of streamflow infiltration from the Big Lost River on water levels in perched

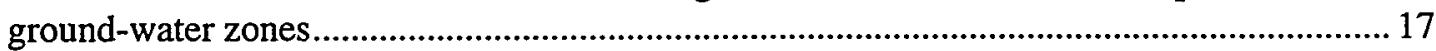

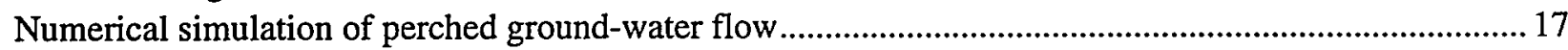

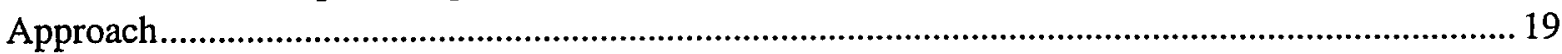

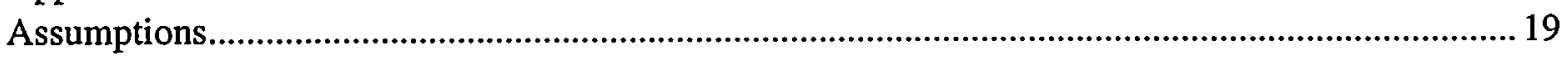

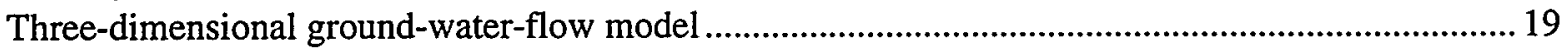

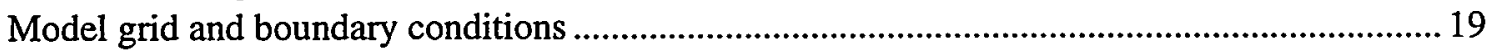

Steady-state estimation of hydraulic properties ...................................................................... 20

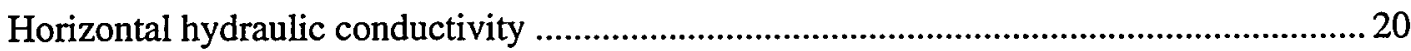

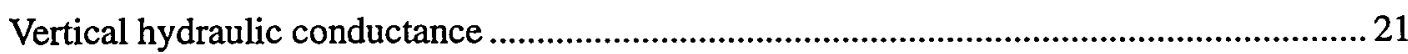

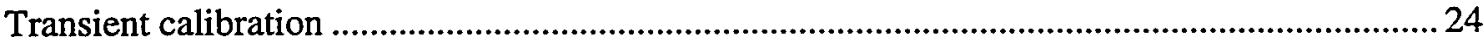

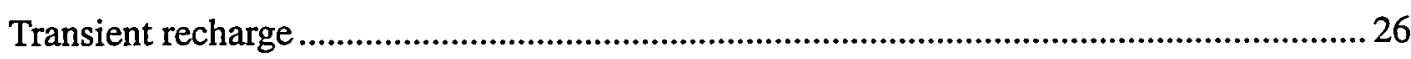

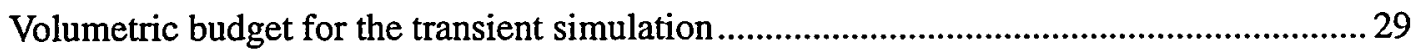

Comparison between simulated transient water levels and measured water levels .............29

Comparison between simulated layer-2 water levels and water levels in wells completed in the BC flow group............................................................................. 30

Comparison between simulated layer-3 water levels and water levels in wells completed in the DE1 flow group ............................................................................. 30 
Comparison between simulated layer-4 water levels and water levels in wells completed in the interbed unit................................................................................ 33

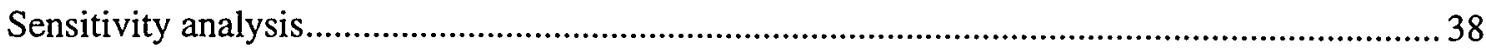

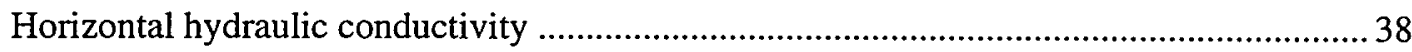

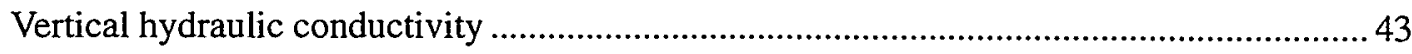

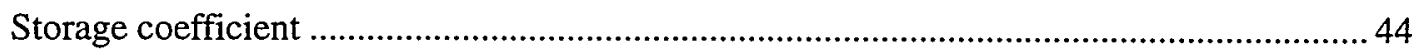

Discussion of numerical simulation results and model limitations ............................................... 44

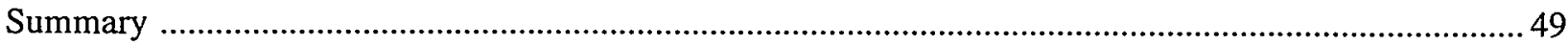

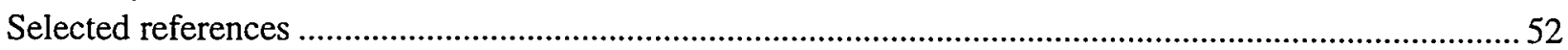

\section{FIGURES}

Figure 1. Map showing location of the Test Reactor Area (TRA), wastewater infiltration ponds, wells completed in TRA perched ground-water zones and the approximate extent of

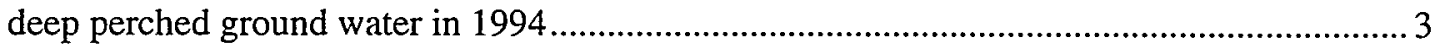

2. Diagram showing conceptual model of perched ground-water flow at the Test Reactor Area .... 6

3. Graphs showing wastewater disposal to infiltration ponds at the Test Reactor Area (TRA) and water-level changes in a well completed in TRA perched ground-water zones ............... 7

4. Hydrographs showing discharge of the Big Lost River at Lincoln Boulevard, streamflow leakage from the INEEL diversion to Lincoln Boulevard, and water levels in selected

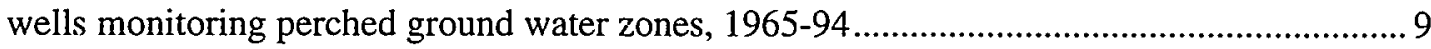

5. Geologic section through the Test Reactor Area ................................................................. 11

6. Map showing isopach of the cumulative thickness of sedimentary interbeds associated with the DE2, DE3, and DE3-4(W) basalt-flow groups at the Test Reactor Area 16

7. Geohydrologic section and diagram showing finite-difference grid, infiltration-pond cells, river cells, and layers used to simulate formation of perched ground-water zones at the Test Reactor Area

8. Diagram showing array of inverse sediment thickness used to simulate the vertical conductance of water through sedimentary interbeds associated with the DE2, DE3, and DE3-4(W) basalt-flow groups at the Test Reactor Area.

9-14. Hydrographs showing

9. Transient simulated layer-2 water levels and measured water levels in wells completed in the $\mathrm{BC}$ flow group at the Test Reactor Area.

10. Transient simulated layer-3 water levels and measured water levels in wells completed in the DE1 flow group at the Test Reactor Area

11. Transient simulated layer-4 water levels and measured water levels in wells completed in the interbed unit at the Test Reactor Area .

12. Transient water levels at the Test Reactor Area simulated using \pm 40 -percent hydraulic conductivity, 1952-94 
13. Transient water levels at the Test Reactor Area simulated using \pm 40 -percent vertical hydraulic conductivity, 1952-94

14. Transient water levels at the Test Reactor Area simulated using \pm 50 -percent storage, 1952-94

15. Map showing comparison between the extent of the known and simulated perched ground-water zones at the Test Reactor Area, December 1994.

\section{TABLES}

Table 1. Well completion data, stratigraphic data, and model layers for wells completed in perched ground-water zones at the Test Reactor Area.

2. Comparison of water levels in wells completed in perched ground-water zones at the Test Reactor Area (October 1990) and steady-state calibrated water levels for corresponding cells

3. Volumes of recharge assigned to specified groups of model cells representing wastewater infiltration ponds at the Test Reactor Area, 1952-94.

4. Cumulative annual recharge assigned to cells representing the channel of the Big Lost River near the Test Reactor Area, 1952-94.

\section{CONVERSION FACTORS AND VERTICAL DATUM}

$\begin{array}{lc}\text { Multiply } & \text { By } \\ \text { inch (in.) } & 25.4 \\ \text { foot (ft) } & 0.3048 \\ \text { foot per day }(\mathrm{ft} / \mathrm{d}) & 0.3048 \\ \text { foot squared per day }\left(\mathrm{ft}^{2} / \mathrm{d}\right) & 0.09290 \\ \text { mile (mi) } & 1.609 \\ \text { square foot }\left(\mathrm{ft}^{2}\right) & 0.09290 \\ \text { square mile }\left(\mathrm{mi}^{2}\right) & 2.590 \\ \text { cubic foot }\left(\mathrm{ft}^{3}\right) & 0.02832 \\ \text { acre-foot }(\mathrm{acre}-\mathrm{ft}) & 1,233 \\ \text { gallon per minute }(\mathrm{gal} / \mathrm{min}) & 3.785\end{array}$

\author{
To obtain SI units \\ millimeter (mm) \\ meter $(\mathrm{m})$ \\ meter per day \\ meter squared per day \\ kilometer \\ square meter \\ square kilometer \\ cubic meter \\ cubic meter \\ liter per minute
}

Sea level: In this report, "sea level" refers to the National Geodetic Vertical Datum of 1929--a geodetic datum derived from a general adjustment of the first-order level nets of the United States and Canada, formerly called Sea Level Datum of 1929. 


\title{
A TRANSIENT NUMERICAL SIMULATION OF PERCHED GROUND-WATER FLOW AT THE TEST REACTOR AREA, IDAHO NATIONAL ENGINEERING AND ENVIRONMENTAL LABORATORY, IDAHO, 1952-94
}

\author{
By Brennon R. Orr
}

\begin{abstract}
Perched ground-water zones have formed in the upper 200 feet of surficial alluvium, basalt, and sedimentary interbeds beneath wastewater infiltration ponds at the Test Reactor Area (TRA) of the Idaho National Engineering and Environmental Laboratory (INEEL). These zones are an integral part of the pathway for contaminants to move to the Snake River Plain aquifer. Water moves rapidly through surficial sediments beneath the wastewater infiltration ponds as primarily vertical, unsaturated and saturated, intergranular flow. The extent of perched ground water in the surficial sediments is limited to the vicinity of infiltration ponds. Water enters underlying basalt through fractures and interflow rubble zones and moves rapidly through the basalt as vertical flow in the fractures and as lateral flow in the rubble zones. Water enters the sedimentary interbeds from the overlying basalt and moves as saturated and unsaturated intergranular flow. When the downward flux exceeds the vertical hydraulic conductivity of the interbeds, perched ground-water zones form and water moves laterally within and above the interbed unit. Vertical flow of water through the interbed unit enters the underlying basalts through fractures and moves as rapid fracture flow to the Snake River Plain aquifer.
\end{abstract}

The approximate lateral dimensions of deep perched ground-water zones in 1988 as defined by monitoring wells were 1 mile by 0.5 mile for an area of about 14 million square feet. The actual extent can only be approximated because of limited well information. This extent is controlled by the horizontal hydraulic conductivity of the unit in which perched water accumulates, by the rate at which downward flow is propagated through the perching layer, and by structural features that can direct or block lateral flow.
Perched water has been detected in the $\mathrm{BC}$ and DE1 basalt-flow groups and in a sedimentary interbed unit associated with the DE2, DE3, and DE3$4(\mathrm{~W})$ flow groups. Water-level data from paired wells in some areas indicated that multiple zones of perched water were separated by unsaturated basalt. Water-level data from paired wells in other areas indicated that saturated flow was relatively continuous through the perched zones.

A four-layer numerical model was used to evaluate perched ground-water flow through the basalts and sediments in the upper 200 feet of the unsaturated zone beneath the TRA. This model treated perched flow as saturated flow and did not represent unsaturated flow properties related to changing moisture content. The first layer represented surficial sediments. The second and third layers represented basalt-flow groups designated as the $\mathrm{BC}$ and $\mathrm{DE} 1$ flow groups, respectively. The fourth layer represented the sedimentary interbeds associated with the DE2, DE3, and DE3-4(W) basaltflow groups and designated as the interbed unit. Calibrated hydraulic conductivity values of 20 and 2 feet per day were uniformly assigned to cells in layers 2 and 3, respectively. Calibrated values of hydraulic conductivity of 0.05 feet per day and vertical hydraulic conductivity of 0.0028 feet per day were assigned to cells in layer 4 to represent finegrained sediment in the interbed unit. An effective porosity of 10 percent was assigned to all layers, and a confined storage coefficient of 0.0001 , derived from the transient model calibration, was assigned to layers 2 through 4 .

Until 1982, the extent of perched ground-water zones was controlled principally by wastewater infiltration from the warm-waste ponds. In 1982, with the onset of wastewater disposal to the coldwaste ponds, perched ground water expanded to the south and water levels in deeper perched wells 
rose substantially. The simulated extent of perched ground-water zones approximated the known extent as determined from water levels in wells near the margins of perched ground-water zones. Comparison between simulated water levels and measured water levels showed that layer 2 poorly to moderately represented these transient hydrologic conditions in the $\mathrm{BC}$ flow group because of insufficient definition of the distribution of hydraulic properties. Layer 3 moderately to closely represented transient conditions in the DE1 flow group. The capability of layer 4 to represent transient conditions in the interbed unit was difficult to assess because most of the wells completed in the interbed were located at or outside the margins of perched water.

A simulation was run that assumed cessation of all wastewater recharge after 1994 . This simulation showed that the perched ground-water zones drained approximately 4 years after cessation of recharge. All cells in layer 2 drained after approximately 6 months. All cells in layer 3 drained approximately 3.5 years after cessation. All cells in layer 4 drained approximately 4 years after cessation. The results of this transient simulation indicate that the BC and DE1 flow groups and the interbed unit will drain quickly in response to cessation of recharge from the TRA wastewater infiltration ponds.

Measured water levels in several wells completed in the perched zones were affected by leakage from intermittent streamflow exceeding 20,000 acre-ft per month. Because short-term streamflow infiltration fluctuations were not well approximated, simulated recharge peaks did not occur in cells representing wells known to be affected by streamflow infiltration. More precise simulation of the periodic commingling of perched ground-water zones underlying the TRA and recharge from the Big Lost River requires finer discretization of time and recharge from streamflow.

\section{INTRODUCTION}

The Idaho National Engineering and Environmental Laboratory (INEEL), encompassing about $890 \mathrm{mi}^{2}$ of the eastern Snake River Plain in southeastern Idaho (fig. 1), is operated by the U.S. Department of Energy (DOE). Facilities at the
INEEL are used in the development of peacetime atomic-energy applications, nuclear safety research, defense programs, and advanced energy concepts. The Test Reactor Area (TRA), one of these facilities, has been in operation since the early 1950's, and is used in support of DOE power reactor programs for research in the performance of reactor materials and equipment.

Wastewater originating from the TRA has been discharged to the subsurface through wastewater infiltration ponds and injection wells (fig. 1) since 1952. The wastewater has contained concentrations of dissolved radiochemical, inorganicchemical, and organic-chemical constituents. The unsaturated zone above the Snake River Plain aquifer at the TRA is approximately $450 \mathrm{ft}$ thick and consists of a complex section of multiple basaltflow groups and intercalated sediments. Water leaking from wastewater infiltration ponds moves down through these basalt-flow groups and sedimentary interbeds to the Snake River Plain aquifer.

Zones of perched ground water have formed in the basalts and sedimentary interbeds in the upper $200 \mathrm{ft}$ beneath wastewater infiltration ponds at the TRA in and above zones of contrasting hydraulic conductivity. These perched zones are an integral part of the pathway for wastewater from the TRA to move to the Snake River Plain aquifer. They include perched water in the alluvial sediment in the vicinity of the ponds and perched zones (fig. 1) that have formed at depth in and above a sequence of thick sedimentary interbeds. The approximate lateral dimensions of deep perched ground-water zones in 1988 as defined by monitoring wells were $1 \mathrm{mi}$ by $0.5 \mathrm{mi}$ for an area of about 14 million $\mathrm{ft}^{2}$. The known lateral and vertical extent can only be approximated because of limited well information. This extent is controlled by the horizontal hydraulic conductivity of the unit in which perched water accumulates, by the rate at which downward flow is propagated through the perching layer, and by structural features that can direct or block lateral flow.

An understanding of the hydrology of perched ground-water zones at the TRA is needed because of the role these zones play in the transport of wastewater constituents to the Snake River Plain aquifer. The U.S. Geological Survey (USGS) con- 


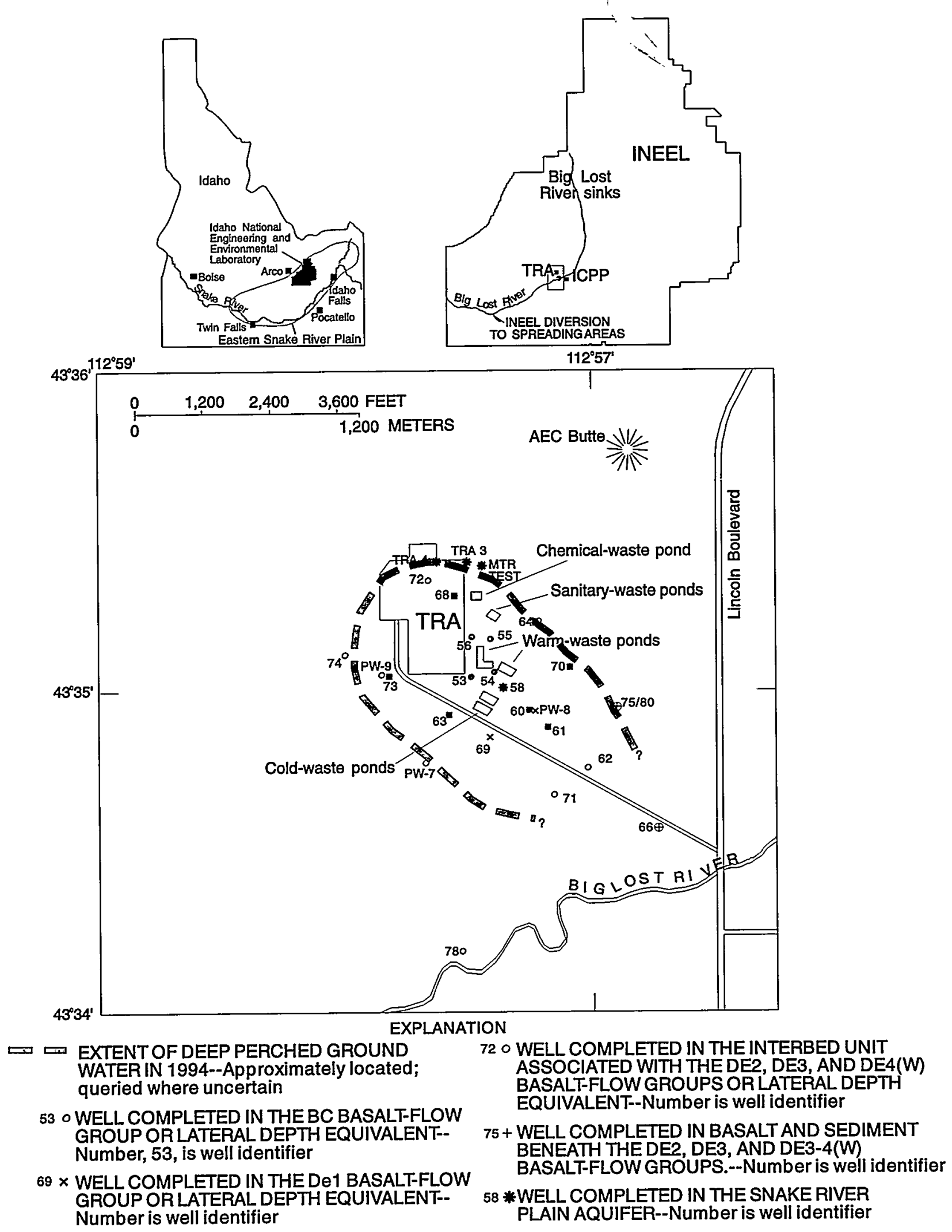

Figure 1.- Location of the Test Reactor Area (TRA), wastewater infiltration ponds, wells completed in TRA perched ground-water zones and the approximate extent of deep perched ground water in 1994. 
ducted this analysis of the formation of perched ground-water zones in cooperation with the Idaho Operations Office of the DOE.

\section{Purpose And Scope}

Studies of flow through the unsaturated zone and perched ground-water zones above the Snake River Plain aquifer are part of the overall assessment of ground-water flow and determination of the fate and transport of contaminants in the subsurface at the INEEL. These studies include definition of the hydrologic controls on the formation of perched ground-water zones and description of the transport and fate of wastewater constituents as they move through the unsaturated zone. The definition of hydrologic controls requires stratigraphic correlation of basalt flows and sedimentary interbeds within the unsaturated zone, analysis of hydraulic properties of unsaturated-zone rocks, numerical modeling of the formation of perched ground-water zones, and batch and column experiments to determine rock-water geochemical processes. This report describes the development of a transient numerical simulation that was used to evaluate a conceptual model of flow through perched ground-water zones beneath wastewater infiltration ponds at the TRA.

\section{Acknowledgments}

The author gratefully acknowledges the support and technical expertise of M.G. McDonald, A.W. Harbaugh, and D.J. Ackerman, both in modification to the Modular Flow Model Block-Centered Flow package that permitted simulation of a transient perched system and in continuing advice and direction throughout the project.

\section{Previous Studies}

Descriptions of the extent of perched ground water at the TRA and the distribution of selected wastewater constituents in perched ground-water zones were presented in a series of reports characterizing the hydrology of the National Reactor Testing Station. These reports included a study by Barraclough and others (1967). An analysis of perched ground-water zones at the TRA was presented in a comprehensive discussion of conditions related to the disposal of liquid waste to the subsur- face at the INEEL (Robertson and others, 1974). Later reports that presented perched ground-water data included those by Barraclough and others (1981), describing hydrologic conditions during 1974-78; Lewis and Jensen (1984), describing hydrologic conditions during 1979-81; and Pittman and others (1988), describing hydrologic conditions during 1982-85.

Hull (1989) developed a conceptual model that described migration pathways for wastewater and constituents from the warm-waste ponds at the TRA. Cecil and others (1991) described mechanisms responsible for the formation of perched ground-water zones at the TRA and Idaho Chemical Processing Plant (ICPP) and described the distribution of chemical and radionuclide constituents in perched water during 1986-88. Tucker and Orr (1998) described the distribution of constituents in perched water during 1989-91; Bartholomay (1998) described the distribution of constituents in perched water during 1992-95.

Anderson (1991) correlated geophysical logs and basalt cores to describe a complex sequence of basalt flows and sedimentary interbeds underlying the TRA and ICPP. This stratigraphic correlation provided an understanding of the geologic framework within which perched ground water has formed beneath the TRA. Ackerman (1991) analyzed data from 43 aquifer tests conducted in 22 wells to estimate the transmissivity of basalts and sedimentary interbeds containing perched groundwater zones beneath the TRA and ICPP.

Robertson (1977) developed a numerical model to simulate flow and transport of chemical and radionuclide constituents in perched ground-water zones beneath the TRA. This model included the effects of convection, hydrodynamic dispersion, radioactive decay, and adsorption. Naylor (1988) constructed a steady-state numerical flow model of perched ground-water zones at the TRA.

\section{CONCEPTUAL MODEL OF PERCHED GROUND-WATER FLOW}

The development of a conceptual model of the geologic and hydrologic systems at the TRA is necessary to describe the flow of water through the perched ground-water zones. This conceptual 
model (fig. 2) integrates the descriptions of recharge to the flow system, the geohydrologic framework, including physical and hydraulic properties of the rocks that store and transmit water, and the hydraulic response of the flow system to spatial and temporal changes in hydrologic conditions. Recharge at the TRA takes place as pointsource recharge through wastewater infiltration ponds, line-source recharge from leakage in the Big Lost River, areal recharge from precipitation, and point-source recharge from irrigation and other sources. Water moves rapidly through the surficial sediments beneath the wastewater infiltration ponds as primarily vertical, unsaturated and saturated, intergranular flow. Water enters underlying basalt through fractures and broken basalt rubble zones at tops of individual flows and moves rapidly through the basalt as vertical, macropore flow in fractures and as lateral flow in rubble zones. This flow can partly or completely fill fractures. Water enters the heterogeneous, layered sedimentary interbeds from the overlying basalt, moving as saturated and unsaturated intergranular flow through an anisotropic porous medium. When the downward flux exceeds the vertical hydraulic conductivity of the interbeds, perched ground-water zones form and water moves laterally above the interbed unit. Water flows vertically through the interbed unit to the underlying basalt and moves rapidly through fractures as unsaturated macropore flow to the Snake River Plain aquifer.

\section{Recharge}

Most of the recharge to perched ground-water zones at the TRA during 1952-94 was from wastewater disposal to the TRA wastewater infiltration ponds. These ponds included warm-waste ponds used principally for disposal of wastewater containing radiochemical constituents, cold-waste ponds used for disposal of cooling-tower blowdown water, a chemical-waste pond used for disposal of wastewater containing certain industrial chemicals, and ponds used for disposal of sanitary wastes. A perched ground-water zone recharged by streamflow infiltration in the Big Lost River intermittently affected parts of the TRA perched ground-water zones. Areal recharge from precipitation probably furnished intermittent, small amounts of recharge. Sprinkler irrigation of land- scaping at the TRA provided an additional source of recharge to shallow, perched ground-water zones.

\section{Recharge from Wastewater Disposal at the Test Reactor Area}

The TRA warm-waste ponds consist of three cells constructed between 1952 and 1964 (fig. 1). The first cell was constructed for disposal of TRA wastewater in 1952. Initially, all wastewater except sanitary wastewater was discharged to this unlined wastewater infiltration pond. In 1957, a second cell was constructed adjacent to the first cell because plugging of the pond bottom had decreased the rate of wastewater infiltration. The second cell was separated from the first cell by an earthen dike and received wastewater from the first cell through a pipe. In 1964, a third cell was constructed adjacent to the first two cells to alleviate continued bottomplugging problems.

After 1964, the warm-waste ponds were used principally for disposal of low-level radioactive wastewater. Disposal to the ponds was discontinued on August 12,1993, when radioactive wastewater was diverted to lined evaporation ponds.

Wastewater discharged to the warm-waste ponds accounted for the largest long-term source of recharge to perched ground-water zones at the TRA. During 1952-93, the warm-waste ponds received about 708 million $\mathrm{ft}^{3}$ of wastewater. Until 1982 , these ponds received most of the wastewater at the TRA (fig. 3). Discharge to the warm-waste ponds peaked several times during 1958-82. During this time, discharge rates ranged from about 7 million to about 38 million $\mathrm{ft}^{3} /$ year. Beginning in 1975, programs were implemented to reduce the volume of the waste stream and the amount of radioactive waste constituents discharged to the warm-waste ponds. From 1983 to August 1993, when use of the warm-waste ponds was discontinued, an average of approximately 2.7 million $\mathrm{ft}^{3} /$ year of radioactive wastewater was discharged to the warm-waste ponds.

In 1962, the chemical-waste pond was constructed $700 \mathrm{ft}$ north of the warm-waste ponds for diversion of nonradioactive wastewater that contained industrial chemicals. Since 1962, this pond 


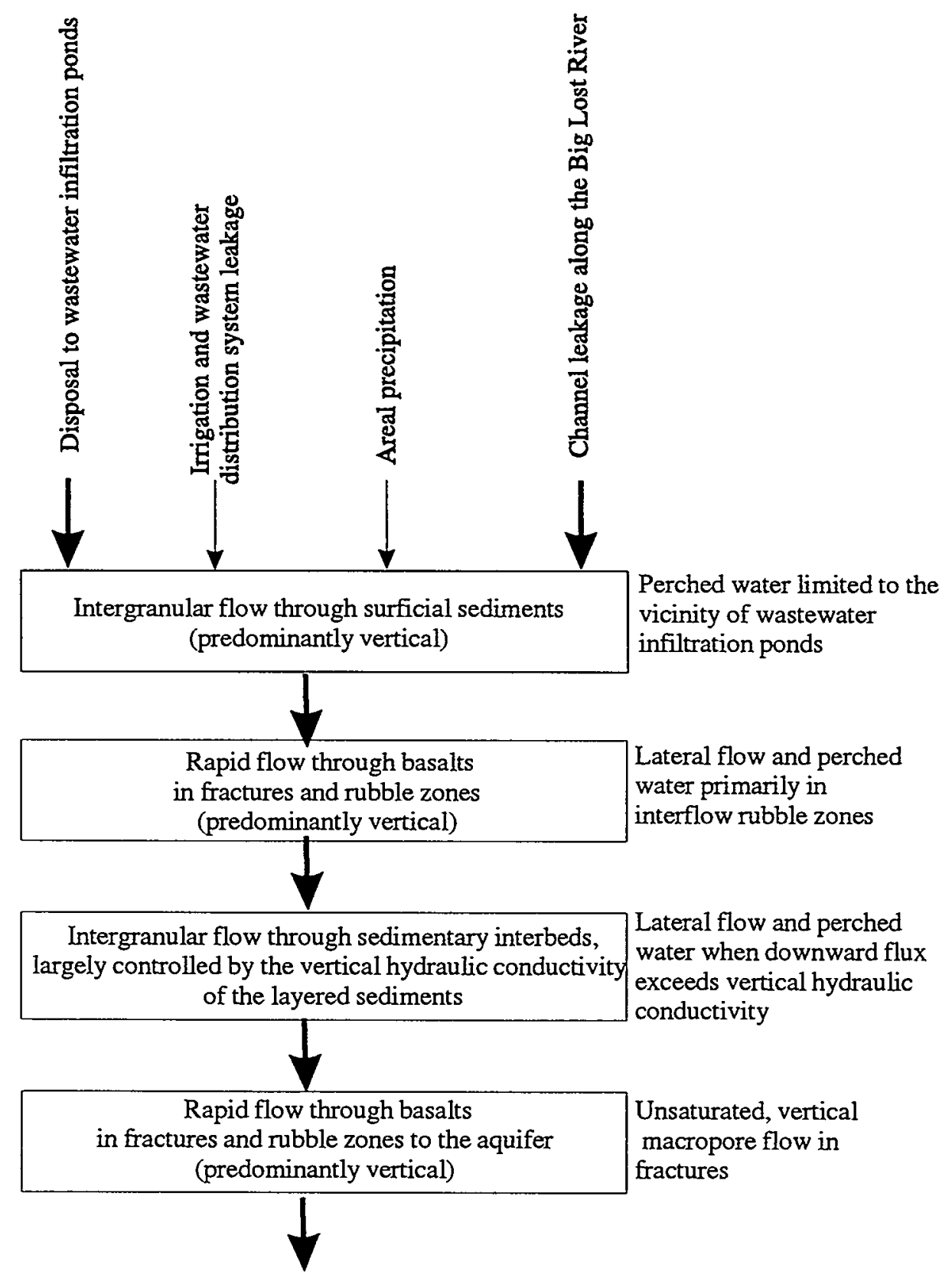

Figure 2.-Conceptual model of perched ground-water flow at the Test Reactor Area. 


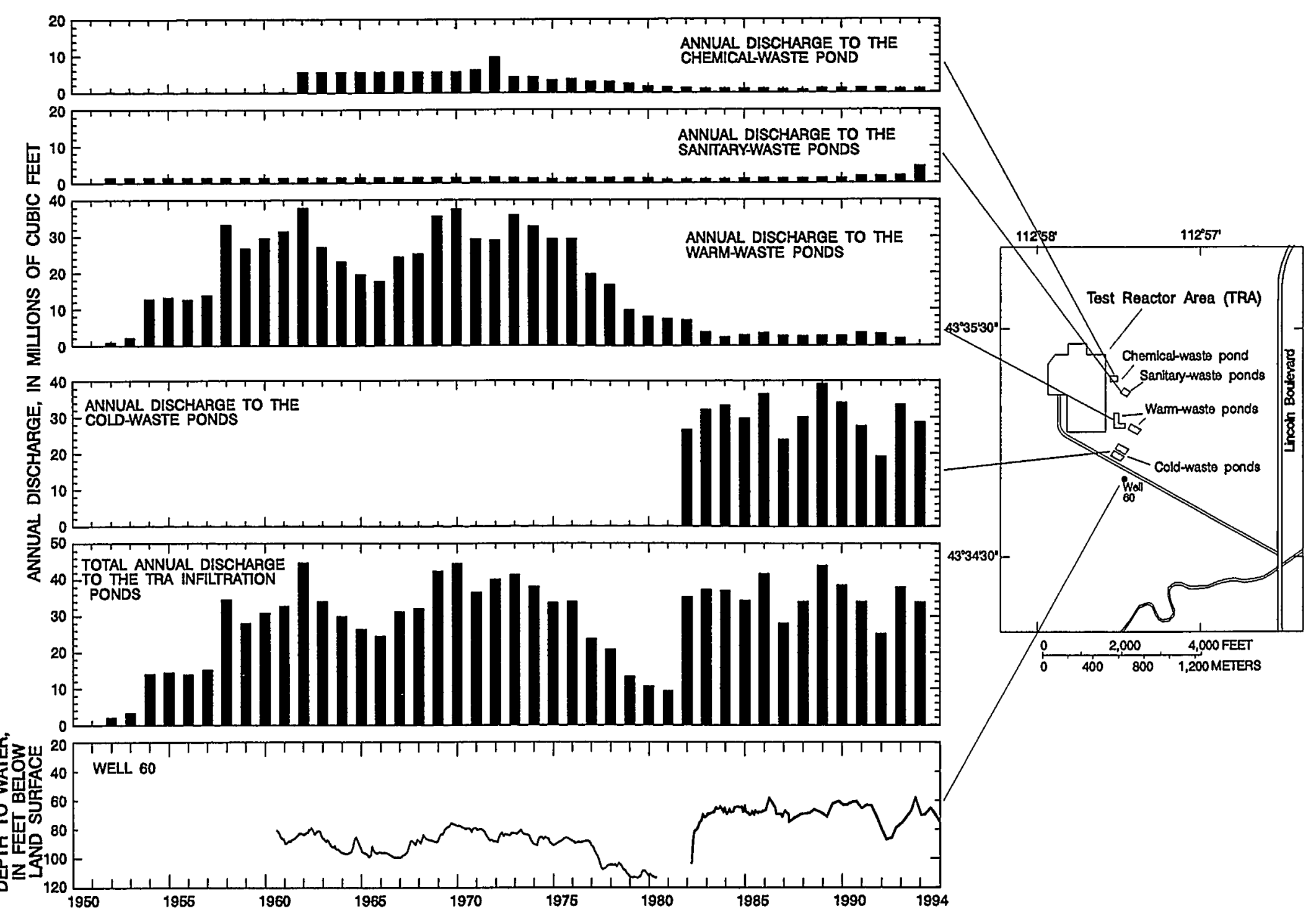

Figure 3.-Wastewater disposal to infiltration ponds at the Test Reactor Area (TRA) and water-level changes in a well completed in TRA perched ground-water zones. 
has been used primarily for disposal of wastewater from ion-exchange columns and water softeners (Hull, 1989, p. 9).

Approximately 104 million $\mathrm{ft}^{3}$ of wastewater was discharged to the TRA chemical-waste pond during 1962-94 amounting to an average disposal rate of about 3.2 million $\mathrm{ft}^{3} /$ year. Disposal to the chemical-waste pond ranged from 0.8 million to 9.7 million $\mathrm{ft}^{3} /$ year (fig. 3 ).

In 1964, a 1,275-ft-deep well (fig. 3) was drilled for direct disposal to the Snake River Plain aquifer of wastewater generated during the cooling-tower blowdown process. Disposal to this well was discontinued in 1982 when the blowdown wastewater was diverted to cold-waste infiltration ponds.

Disposal to the cold-waste infiltration ponds accounted for the second largest source of recharge to perched ground-water zones at the TRA, despite the fact that they were not constructed until 1982. Since 1982, the cold-waste infiltration ponds have received most of the wastewater discharged at the TRA (fig. 3). Approximately 394 million $\mathrm{ft}^{3}$ of wastewater was discharged to the cold-waste infiltration ponds during 1982-94, amounting to an average disposal rate of about 30 million $\mathrm{ft}^{3} /$ year. Cold-waste pond disposal rates ranged from about 19 million to 39 million $\mathrm{ft}^{3} /$ year.

An unlined sanitary-waste pond was constructed in 1950. A second sanitary-waste pond was constructed in 1965. These two ponds, located between the chemical-waste pond and warm-waste ponds, have received all sewage wastewater since 1950.

The TRA sanitary-waste ponds received about 55 million $\mathrm{ft}^{3}$ of water during 1952-94. Sanitary wastewater disposal at the TRA ranged from 700,000 to 4.4 million $\mathrm{ft}^{3} /$ year and averaged about 1.3 million $\mathrm{ft}^{3} /$ year (fig. 3 ).

\section{Recharge from the Big Lost River}

The channel of the Big Lost River (fig. 1) intersects Lincoln Boulevard approximately $5,000 \mathrm{ft}$ southeast of the TRA wastewater infiltration ponds. Stream discharge at Lincoln Boulevard has been monitored since 1965. Flow in the Big Lost River at Lincoln Boulevard bridge is intermittent (fig. 4) and is dependent upon snowpack in the Big Lost River drainage basin, upstream irrigation diversions, and snowmelt at the INEEL. Bennett (1990, p. 45) estimated discharge at the Lincoln Boulevard bridge from unpublished records prior to 1984 and from published records during 1984-94. Large discharges occurred during 1965 , $1967,1969-71,1974,1975$, and 1982-86. No flow took place during 1977-79 and during 1988-92.

Instantaneous losses from the Big Lost River channel between Arco and the Big Lost River sinks (fig. 1) were estimated from seepage-run measurements and ranged from 1 to $2 \mathrm{ft}^{3} / \mathrm{s}$ per river mile during periods of flow less than $100 \mathrm{ft}^{3} / \mathrm{s}$ (Bennett, 1990 , p. 24). When flow exceeded $100 \mathrm{ft}^{3} / \mathrm{s}$, losses exceeded $2 \mathrm{ft}^{3} / \mathrm{s}$ per river mile. Monthly losses during 1965-94 (fig. 4) in the Big Lost River reach from the INEEL diversion to Lincoln Boulevard (fig. 1) were estimated by subtracting discharge at Lincoln Boulevard from discharge downstream from the diversion. These losses occurred in the $10.7 \mathrm{mi}$ of channel between the diversion and Lincoln Boulevard (Bennett, 1990, p. 8). Some of these losses could represent flow downstream from the diversion that had totally infiltrated far upstream from the bridge.

\section{Recharge from Direct Precipitation}

Annual precipitation in the vicinity of the TRA averages about 8 in. Cecil and others (1992, p. 713) estimated that the net infiltration of natural water through the upper $20 \mathrm{ft}$ of unsaturated soil at the RWMC ranges from 2 to 5 percent of average annual precipitation. If areal recharge at the TRA is assumed to be similar, direct recharge from precipitation could range from 0.4 to 0.9 million $\mathrm{ft}^{3}$ per square mile per year, an inconsequential amount compared with recharge volumes from other sources.

\section{Recharge from Irrigation and Other Sources}

During 1975-94, an average of 4.4 million $\mathrm{ft}^{3} /$ year of water was used for landscape irrigation at the TRA. Prior to 1984 , some wastewater was discharged to the desert near the TRA. Leakage from wastewater distribution systems occurred during 1952-94. These potential sources of 

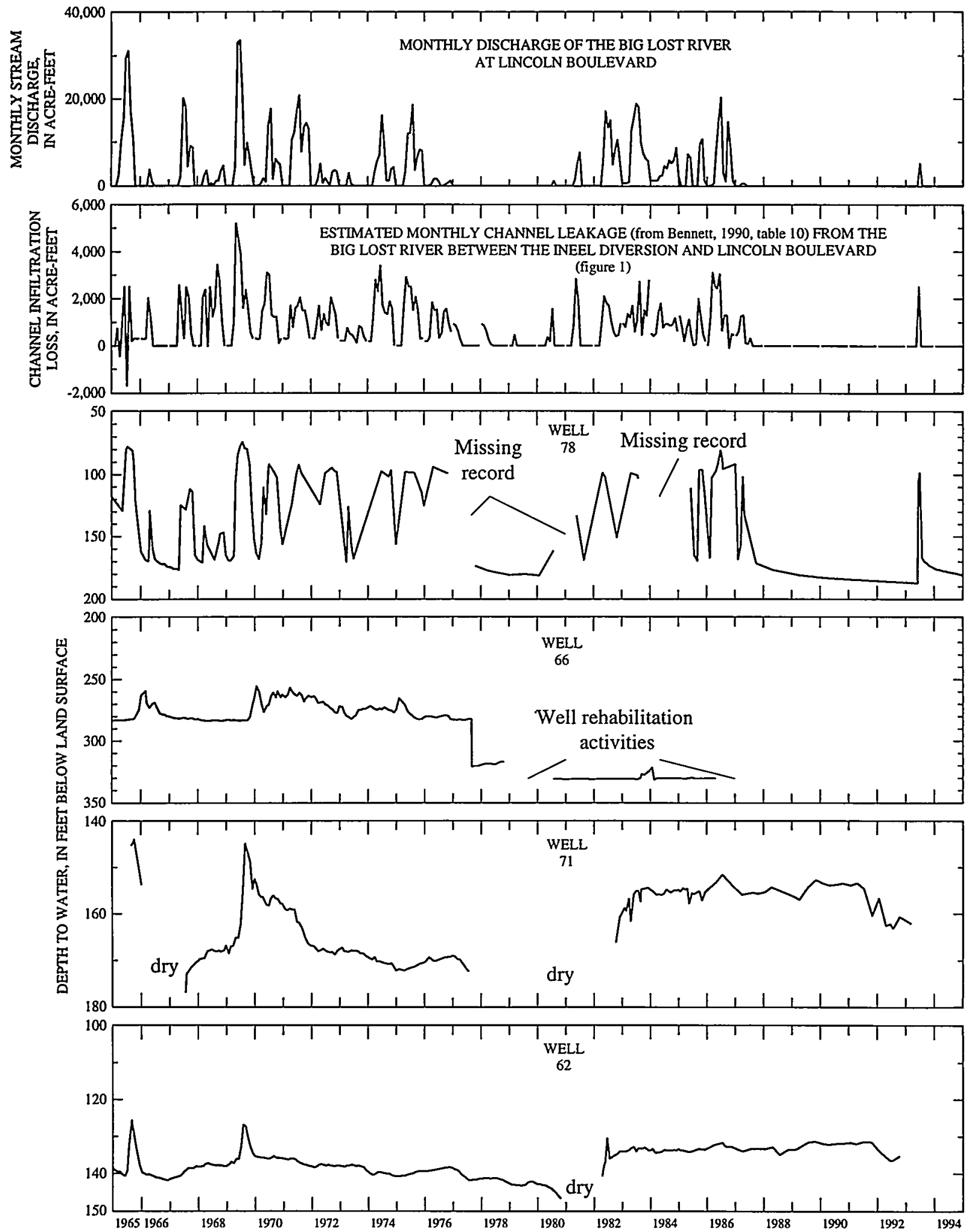

Figure 4.-Discharge of the Big Lost River at Lincoln Boulevard, streamflow leakage from the INEEL diversion to Lincoln Boulevard, and water levels in selected wells monitoring perched ground-water zones, 1965-94. 
recharge could affect perched ground-water zones at the TRA, but the actual volumes and locations of these sources are not known.

\section{Geohydrologic Framework}

The complex stratigraphic relations between multiple basalt flows from many source areas and the sedimentary interbeds underlying the TRA provide the framework for transporting and perching wastewater leaking from the TRA wastewater infiltration ponds. The unsaturated zone at the TRA consists of a layer of surficial sediment and a complex sequence of as many as 17 basalt-flow groups and 8 sedimentary interbeds (Anderson, 1991, figs. 3, 4, and 6). At the TRA, Anderson (1991) identified these flow groups as the BC through the I flow groups (fig. 5). Each flow group consists of one to three petrographically similar flows that erupted from a vent or fissure during a short period of geologic time.

Basalt-flow groups and sedimentary interbeds underlying the TRA are laterally discontinuous and characterized by large changes in thickness over short distances. Eruptive sequences were separated by long periods of volcanic inactivity during which sedimentary interbeds were deposited. These interbeds consist of fluvial, lacustrine, and eolian deposits of clay, silt, sand, and gravel. Perched ground water occurs in the surficial sediment, in basalt-flow groups $\mathrm{BC}$ and $\mathrm{DE} 1$, and in the interbed unit associated with the DE2, DE3, and DE34(W) flow groups (Anderson, 1991). The capability of underlying and adjacent flow groups to transmit water is either very large, resulting in unsaturated flow along fractures, or smaller, resulting in boundaries to vertical and horizontal flow.

\section{Surficial Sediment}

Surficial sediment was penetrated in 35 wells in the vicinity of the TRA and ranges from 15 to $73 \mathrm{ft}$ thick (Anderson, 1991, fig. 9); mean thickness is $49 \mathrm{ft}$. The surficial sediment is thickest beneath wastewater infiltration ponds and along the Big Lost River. The top of the basalt beneath the surficial sediment forms an irregular trough; its axis dips approximately southeast from the TRA toward the ICPP. Relief on the surface of the basalt (Anderson, 1991, fig. 10) is about $40 \mathrm{ft}$. Surficial sediment near the TRA is derived from channel and overbank deposits from the Big Lost River and consists predominantly of gravel and sand (Bartholomay and others, 1989, table 3). In one sample, BLRB-8, collected from the Big Lost River channel between the TRA and ICPP, 67.2 percent by weight of the sample consisted of gravel exceeding $2.0 \mathrm{~mm}$ in diameter; 30.7 percent by weight consisted of fine sand ( 0.125 to $0.25 \mathrm{~mm}$ ) to very fine gravel $(2.0 \mathrm{~mm})$. The sediment distribution in this sample is typical of that of surficial sediment in the vicinity of the TRA. Quartz and plagioclase feldspar were the most abundant minerals in surficial sediment samples (Bartholomay and others, 1989, p. 23).

\section{Basalt-Flow Group BC and Related Sediment}

Basalt-flow group $\mathrm{BC}$, a locally extensive group of flows, consists of two flows originating from an unidentified vent southeast of the ICPP (Anderson, 1991, p. 17). Near the TRA, this basaltflow group is fully penetrated by 27 wells and is not present in 5 wells. Thickness ranges from $0 \mathrm{ft}$, where it laps against basalt-flow group I on AEC Butte northeast of the TRA and against basalt-flow group DE1 west of the TRA, to $61 \mathrm{ft}$ in well 60 (Anderson, 1991, fig. 11). The mean thickness in wells where the BC flow group is present is $40 \mathrm{ft}$. The base of basalt-flow group BC dips generally to the southeast and east. Wells that penetrate basaltflow group BC at and near the TRA contain no thicknesses of related sediment, with the exception of wells 72 and TRA-4, which contain 10 and 11 percent of the thickness penetrated, respectively (Anderson, 1991, p. 66, 69).

\section{Basalt-Flow Group DE1 and Related Sediment}

Basalt-flow group DE1 consists of one to two thick flows that originated from an unidentified source vent northwest of the TRA (Anderson, 1991, p. 18). Near the TRA, this basalt-flow group is fully penetrated by 22 wells and is not present in 3 wells. Thickness ranges from $0 \mathrm{ft}$, where it laps against basalt-flow group I on AEC Butte to the northeast of TRA, to more than $100 \mathrm{ft}$ in the area west of the TRA (Anderson, 1991, fig. 13). The mean thickness in wells where the DE1 flow group is present is $57 \mathrm{ft}$. At the TRA, the base of basaltflow group DE1 dips generally to the south. Wells 


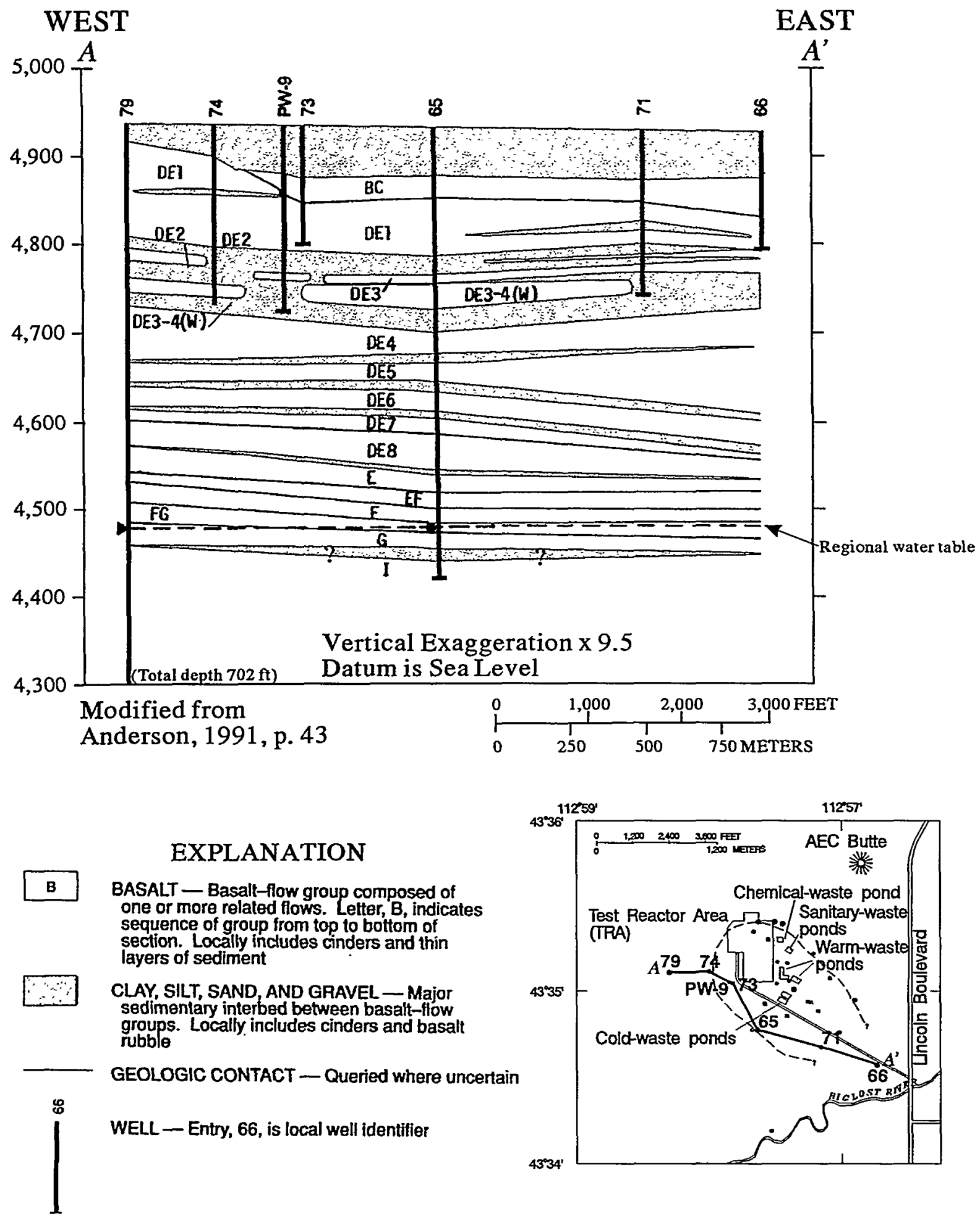

Figure 5.-Geologic section through the Test Reactor Area [modified from Anderson, fig. 4]. 
penetrating basalt-flow group DE1 at and near the TRA contain no thicknesses of related sediment, with the exception of wells $71,74,84$, MTR Test, and TRA-3, which contain $14,3,8,15$, and 12 percent of the thickness penetrated, respectively (Anderson, 1991, p. 66, 69).

\section{Interbed Unit Associated with Basalt-Flow Groups DE2, DE3, and DE3-4(W)}

Basalt-flow groups DE2, DE3, and DE3-4(W) consist of multiple flows that originated from source vents northeast of the ICPP, southeast of the ICPP, and northwest of the TRA (Anderson, 1991, p. 18). Near the TRA, these basalt-flow groups are fully penetrated by 14 wells (cumulative thickness from 45 to $89 \mathrm{ft}$ ) and are not present in 3 wells where the flow groups lap against basalt-flow group I on AEC Butte northeast of the TRA (Anderson, 1991, fig. 15). The mean thickness in wells where the DE2, DE3, and DE3-4(W) flow groups are present is $75 \mathrm{ft}$.

At the TRA, thick sedimentary interbeds, identified in this report as the interbed unit, are associated with the DE2, DE3, and DE3-4(W) basaltflow groups. Thickness of the interbed unit ranges from 8 to 100 percent of the cumulative penetrated thickness with a mean of 86 percent. The formation of the perched ground-water zones at the TRA is attributed principally to the small vertical hydraulic conductivity of the interbed unit.

\section{Basalt-Flow Groups and Related Sediment Underlying Perched Ground Water at the Test Reactor Area}

Beneath the perched ground-water zones at the TRA, downward movement of water to the Snake River Plain aquifer occurs largely as unsaturated flow in basalt-flow groups described by Anderson (1991) as DE4 through FG. The neutron log from well 58, a well completed in the Snake River Plain aquifer and located between the TRA warm-waste ponds and the cold-waste ponds (fig. 1), indicates that unsaturated flow conditions exist beneath the interbed unit associated with the DE2, DE3, and DE3-4(W) flow groups (Cecil and others, 1991, p. 22).
Flow group I erupted from AEC Butte, northeast of the TRA (Anderson, 1991, fig. 3). Because of the proximity of the TRA to AEC Butte, flow groups containing perched ground water at the TRA lap against AEC Butte, where the massive basalts of flow group I and overlying fine-grained sediments limit the potential for lateral flow (Anderson, 1991, p. 33). Perched water was not detected in wells 75 and 80 (fig. 1), both penetrating the I flow group and overlying sediments.

\section{Hydraulic Properties}

The movement of water through basalts of the eastern Snake River Plain is dominated by flow through large fractures and rubble zones, although flow in microfractures in the basalt matrix can permit a secondary flow component. Water moves through surficial sediments and through the interbed unit as intergranular flow; the saturated and unsaturated hydraulic conductivity of these units depends upon the sediment texture and grain-size distribution. Saturated hydraulic properties of basalts and interbeds that control perched groundwater flow beneath the TRA include horizontal and vertical hydraulic conductivity and the unconfined storage coefficient, approximated by the effective porosity of the rock.

\section{Horizontal Hydraulic Conductivity}

Horizontal hydraulic conductivity represents the capability of a unit thickness of water-bearing rocks to horizontally transmit water of a given kinematic viscosity and temperature. Horizontal hydraulic conductivity, approximated by dividing the transmissivity by the saturated thickness, is used to describe the bulk permeability of saturated rocks in the horizontal plane of perched groundwater zones at the TRA. Horizontal hydraulic conductivity estimates are based on assumptions of radial flow in isotropic porous media. These assumptions are not fully met in the basalt and sedimentary interbeds containing perched ground water at the TRA. The capacity of the basalts to transmit water is not uniformly distributed throughout the thickness but is localized within fractures or rubble zones. 
The surficial sediments predominantly consist of gravel and sand. Robertson (1977, p. 21)

reported that permeability determined in the laboratory on auger-cored samples ranged from 0.13 to $1,340 \mathrm{ft} / \mathrm{d}$.

Robertson (1977, p. 25) suggested that the saturated hydraulic conductivity of basalts containing perched ground water at the TRA was approximately $10 \mathrm{ft} / \mathrm{d}$. Since then, single-well aquifer tests have been conducted in 22 INEEL wells that are completed in perched ground-water zones. These wells are located at the TRA and ICPP. Transmissivity estimates from aquifer-test analyses ranged from 1.0 to $15,000 \mathrm{ft}^{2} / \mathrm{d}$ (Ackerman, 1991, p. 10). Ackerman (1991, p. 22) estimated that the saturated hydraulic conductivity of basalt and interbeds in perched ground-water zones at the INEEL varied over nearly 5 orders of magnitude ( 0.014 to 790 $\mathrm{ft} / \mathrm{d})$.

Four of the wells with aquifer-test data evaluated by Ackerman (wells 53, 54, 55, and 56) are located near the TRA wastewater infiltration ponds (fig. 1) and are completed within the BC flow group (Anderson, 1991, table 1). The transmissivity estimates of partial thicknesses of the $\mathrm{BC}$ flow group basalts penetrated by these wells ranged from 99 to $15,000 \mathrm{ft}^{2} / \mathrm{d}$ (Ackerman, 1991, p. 10). The estimated saturated hydraulic conductivity in the vicinity of wells completed in the $\mathrm{BC}$ flow group at the TRA ranged from about 5 to $790 \mathrm{ft} / \mathrm{d}$; the median was $24 \mathrm{ft} / \mathrm{d}$. The wide range of hydraulic conductivity estimates probably is attributable to the presence or absence of fractures in the vicinity of the well. These estimates, based on the assumption of radial flow to the well, provide a realistic approximation of the lower and upper bounds for horizontal hydraulic conductivity of a block of basalt of the modeled cell dimensions.

An aquifer-test was conducted on well 69 , completed in the DE1 flow group, and on well 62, completed in the lower part of the DE1 flow group and in clays of the upper part of the interbed unit. Ackerman (1991, p. 10) reported transmissivities for wells 69 and 62 of $5.6 \mathrm{ft}^{2} / \mathrm{d}$ and $2,800 \mathrm{ft}^{2} / \mathrm{d}$, respectively. Estimated values of saturated hydraulic conductivity were $0.11 \mathrm{ft} / \mathrm{d}$ for well 69 and $88 \mathrm{ft} / \mathrm{d}$ for well 62 . The hydraulic conductivity estimate for well 69 probably is more representative of the hori- zontal hydraulic conductivity of the DE1 flow group because individual flows in the DE1 flow group are thicker than those in the $\mathrm{BC}$ flow group, and these flows are characterized by thicker sections of massive, unfractured basalt, with fewer rubble and fracture zones and with correspondingly smaller horizontal hydraulic conductivity than that of the $\mathrm{BC}$ flow group.

The wide range of saturated horizontal hydraulic conductivity estimates for the $\mathrm{BC}$ and $\mathrm{DE} 1$ flow groups within a small area is typical of a fractured basalt. Larger hydraulic conductivities probably represent localized, highly interconnected fracture zones in the basalt in the vicinity of the well. Also, the volume of saturated rock sampled by these tests is limited by small discharge rates, ranging from less than 1 to $10 \mathrm{gal} / \mathrm{min}$, and short test durations, ranging from 5 minutes to 3.25 hours. Ackerman (1991, p. 6) listed other problems that limit the ability to interpret aquifer-test data. Actual hydraulic conductivity values, averaged for large volumes of saturated basalts in the $B C$ and DE1 flow groups at the TRA, probably are at the lower end of the reported aquifer-test estimates and could range from less than 1 to $20 \mathrm{ft} / \mathrm{d}$.

An aquifer test was conducted on well PW-8, completed in basalt and associated sediment of the upper part of the interbed unit. Completion intervals in this well consist largely of sediment. Transmissivity was estimated from a single-well test to be $220 \mathrm{ft}^{2} / \mathrm{d}$ (Ackerman, 1991, p. 10); the hydraulic conductivity estimate was $2 \mathrm{ft} / \mathrm{d}$. The small discharge rate $(9.4 \mathrm{gal} / \mathrm{min})$ and short test duration (120 minutes) probably limit extrapolation of this estimate to large areas of saturated sediment in the interbeds associated with the DE2, DE3, and DE34(W) flow groups.

Bartholomay and others (1989, table 17) tabulated the bulk mineralogy of interbed sediment at the INEEL as reported in previously published studies. A total of 105 samples were analyzed for the bulk percentage of clay-sized fractions. Claysized fractions ranged from 0 to 70 percent; median and mean values were about 25 percent. Bartholomay and others (1989, table 22) also reported grain-size distributions from previously published studies. Complete grain-size analyses from a total of 60 interbed samples from depths exceeding 
$100 \mathrm{ft}$ were available. These 60 samples, most from wells in the vicinity of the Radioactive Waste Management Complex (RWMC), were composed of an average of 20 percent clay (less than $0.004 \mathrm{~mm}$ in diameter) and 50 percent very fine to fine-grained sand $(0.004$ to $0.012 \mathrm{~mm})$.

Todd (1980, p. 71) reported that the saturated hydraulic conductivity of clay, silt, fine-grained sand, and medium-grained sand typically ranged from 0.0002 to 12 meters/d, or about 0.00067 to 40 $\mathrm{ft} / \mathrm{d}$. Laboratory determinations of saturated hydraulic conductivity for sediment from the RWMC ranged from $1 \times 10^{-8}$ to $7 \times 10^{-3}$ centimeters/s or $3 \times 10^{-5}$ to $20 \mathrm{ft} / \mathrm{d}$ (McElroy and Hubbell, 1990 , p. 53). Based on the large percentage of finegrained sediment in the interbeds, this range probably is representative of the range of horizontal hydraulic conductivity of the thick section of sediments in the interbed unit at the TRA.

The moisture content of the sedimentary interbeds affects hydraulic conductivity. As moisture content increases, the hydraulic conductivity of an unsaturated medium also increases (Freeze and Cherry, 1979, p. 41). Maximum hydraulic conductivity is reached only when the medium is fully saturated. Therefore, the partially saturated basalt and sediment at the margins of perched ground-water zones are characterized by reduced hydraulic conductivity, which probably affects the horizontal extent of perched ground water.

\section{Vertical Hydraulic Conductivity}

The vertical hydraulic conductivity of the surficial sediments is dependent on the presence of layered, fine-grained sediments at the sediment-basalt contact. Robertson (1977, p. 25) estimated that the average vertical hydraulic conductivity of the surficial sediments could be $1 \mathrm{ft} / \mathrm{d}$ based on grain-size distribution, layering, and laboratory analyses of hydraulic properties.

The vertical hydraulic conductivity of the basalts underlying the TRA is dependent on the distribution of vertical fractures and fracture infilling and probably is several orders of magnitude smaller than the horizontal hydraulic conductivity because sections in the basalts typically are massive and unfractured, and because rubble zones are more interconnected horizontally. The fractures in the basalts both above and below the interbed unit are capable of transporting large quantities of water, and the vertical hydraulic conductivity of the basalts probably is larger than that of the sedimentary interbeds.

The downward flux of water through the sedimentary interbeds is controlled by the vertical hydraulic conductivity of the interbeds. Robertson (1977, p. 26) reported that the saturated vertical hydraulic conductivity of sedimentary interbeds near the RWMC, determined from 28 core samples, ranged from 0.0000007 to $10 \mathrm{ft} / \mathrm{d}$; the arithmetic mean was $1 \mathrm{ft} / \mathrm{d}$. According to Robertson, the effective overall vertical permeability of the interbed is weighted toward the layers with the smallest permeability and can be better estimated using the harmonic mean of the permeability. At the RWMC, the harmonic mean of the vertical hydraulic conductivity of the 28 samples was 0.000011 $\mathrm{ft} / \mathrm{d}$. Robertson concluded that the vertical hydraulic conductivity of sedimentary interbeds ranged from 0.00001 to $0.1 \mathrm{ft} / \mathrm{d}$.

The average vertical hydraulic conductivity of the interbed unit was estimated from known fluxes through the perched ground-water zones. During $1987-88$, approximately $85,000 \mathrm{ft}^{3} / \mathrm{d}$ of wastewater was discharged to the wastewater infiltration ponds. Total pond disposal during 1987-88 increased slightly. The approximate lateral dimensions of the perched ground-water zone during this time as defined by monitoring wells were $1 \mathrm{mi}$ by $0.5 \mathrm{mi}$ for an area of about 14 million $\mathrm{ft}^{2}$. A unit hydraulic gradient was assumed to be present across the interbeds because geophysical logs indicate unsaturated flow conditions beneath them. The estimated flux through the sedimentary interbeds $\left(85,000 \mathrm{ft}^{3} / \mathrm{d}\right)$, divided by the estimated area of perched ground water (14 million $\mathrm{ft}^{2}$ ), and divided by the assumed hydraulic gradient of $1 \mathrm{ft} / \mathrm{ft}$ equals an estimated average vertical hydraulic conductivity of $0.006 \mathrm{ft} / \mathrm{d}$. This estimate, within the range estimated by Robertson (1977, p. 26), represents a maximum estimate of the vertical hydraulic conductivity because the hydraulic gradient may exceed unit gradient in places within the interbed and because of possible slight increases in storage due to increased disposal. 
The vertical rate of flow of water through the sedimentary interbeds is dependent upon the interbed thicknesses. The line of equal cumulative interbed thickness beneath the TRA (q) was derived from the thickness measured in wells penetrating interbeds related to the $\mathrm{DE} 2, \mathrm{DE} 3$, and DE3-4(W) basalt-flow groups (Anderson, 1991, table 1). The line of equal thickness indicated that the interbeds are thickest in a lobe that extends southeastward from the TRA; the basalt-flow groups and related interbeds thin to the southwest and also to the northeast, where they lap against thick basalts originating from AEC Butte.

The unsaturated basalts beneath the perched ground-water zones contain minimal thicknesses of sediment. The absence of significant saturated zones in these underlying basalts suggests that water moves predominantly as unsaturated fracture flow.

\section{Storage Coefficient}

The storage coefficient of an unconfined aquifer is approximated by the effective porosity of the rock, defined as the ratio of interconnected voids to total rock volume. Voids in Snake River Plain basalts include large-aperture fractures, microfractures, rubble-zone interstices, and vesicles. Nace and others (1959, p. 61) suggested that the average effective porosity of basalts near the INEEL is about 0.05. Barraclough and others (1967, p. 63) reported that long-term tests probably would result in a range of effective porosity from 0.05 to 0.15 .

Robertson (1977, p. 31) used an effective porosity of about 10 percent in a numerical analysis of flow through the TRA perched ground-water zones. Garabedian (1992, p. F11) reported that the average unconfined storage coefficient for the Snake River Plain aquifer is about 0.05 .

Laboratory determinations of total porosity were made on more than 1,500 basalt samples from test holes and outcrops near the south side of the INEEL (Knutson and others, 1990, 1992). The median values of effective porosity were 0.11 for nonvesicular samples and 0.22 for vesicular samples (Knutson and others, 1992, p. 4-21). The median value of effective porosity for 71 core sam- ples from a vesicular basalt block (Bishop, 1991, p. 77 ) was 0.23 . Field-scale effective porosity values should exceed laboratory values because of the presence of interflow rubble zones and large fractures. Ackerman (1995, p. 10) selected a probable range of values from 0.10 to 0.25 for the effective porosity of the Snake River Plain aquifer. This range is similar to the range of observed values and is only slightly larger than the range of values suggested by other studies. On the basis of these estimates of total and effective porosity, the unconfined storage coefficient for basalts underlying the TRA could range from 0.05 to 0.20 . This range is dependent, in part, on the occurrence of vesicles, fractures, and interflow rubble zones.

Robertson (1977, p. 21) reported a range in porosity from 25 to 45 percent for the surficial sediments. Laboratory determinations of effective porosity for 11 core samples collected from sedimentary interbeds at the RWMC ranged from 34.2 to 51.4 percent (McElroy and Hubbell, 1990, p. 23). However, because of the difficulty in obtaining undisturbed samples of sedimentary interbeds, the unconfined storage coefficient for the interbed unit is not well defined.

\section{Hydraulic Response of Perched Ground- Water Zones to Changes in Hydrologic Conditions}

The hydraulic response of perched groundwater zones to recharge is reflected by water-level changes in wells completed in these zones. These water-level changes are related to wastewater disposal, and, in several instances, to flow in the Big Lost River. Monitoring wells were completed at different intervals within the perched ground-water zones (table 1).Vertical flow within the perched ground-water zones typically is characterized by large hydraulic gradients. The water level in a specific well represents a composite of water levels over the completion interval. Although the variability of completion intervals and the large gradients represented by the composited water levels preclude comparison between specific water levels from well to well, water-level trends between wells can be compared. 


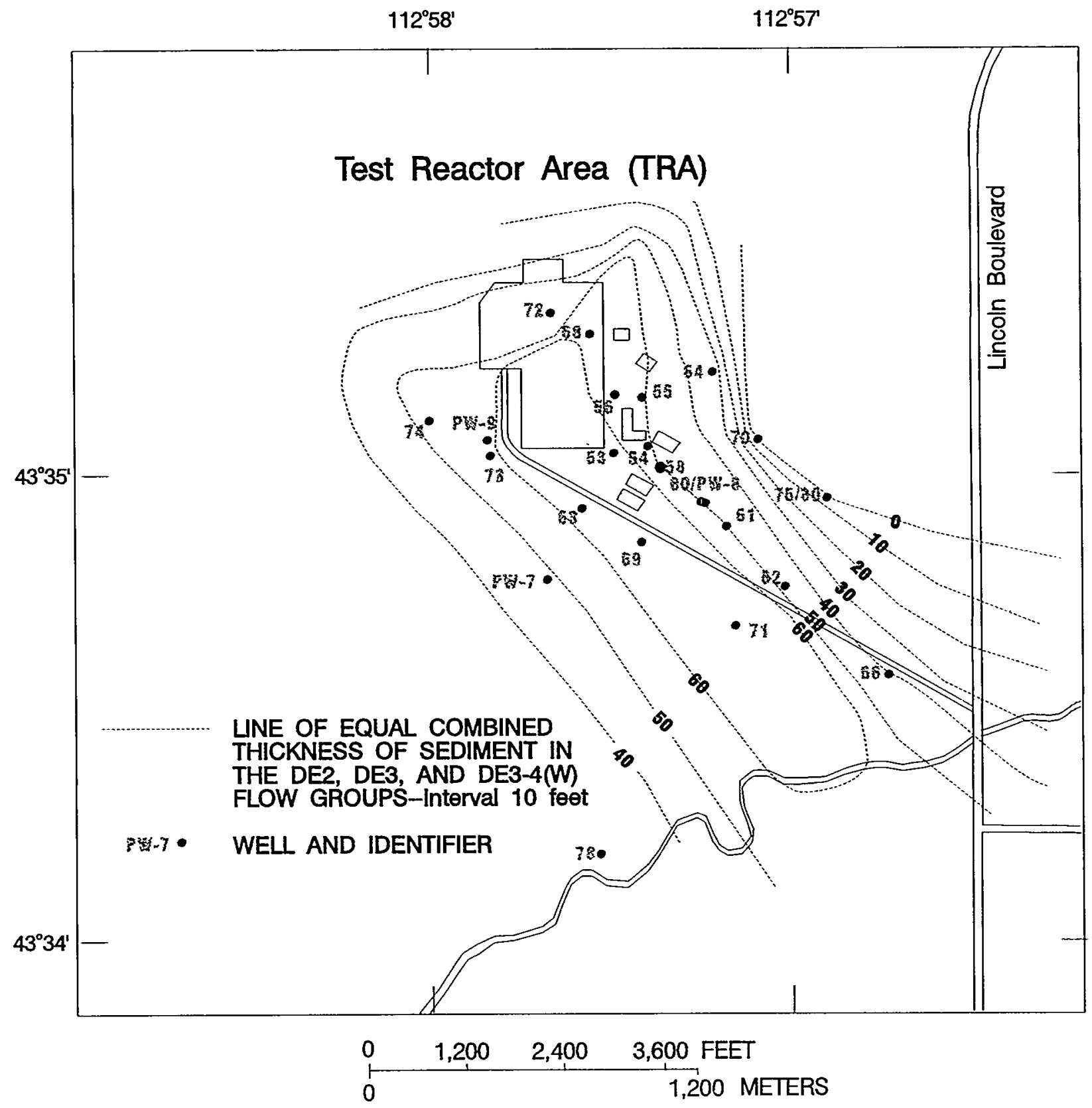

Figure 6.-Isopach of the cumulative thickness of sedimentary interbeds associated with the DE2, DE3, and DE3-4(W) basalt-flow groups at the Test Reactor Area. 
The Effect of Wastewater Disposal on Water Levels in Perched Ground-Water Zones

The distribution of wastewater disposal clearly affected water levels in monitoring wells in deep perched zones at the TRA. A hydrograph of well 60 (fig. 3), completed in the lower part of the $B C$ flow group and the upper part of the DE1 flow group and located east of the warm-waste and coldwaste ponds, shows the water-level response to changes in disposal to the warm-waste ponds during the 1960's, declining warm-waste pond disposal during 1975-82, and the onset of disposal to the cold-waste pond in 1982. Water-level data from auger holes in surficial sediments indicated that shallow perched water did not extend away from the ponds (Robertson, 1977, p. 9).

\section{The Effect of Streamflow Infiltration from the Big Lost River on Water Levels in Perched Ground-Water Zones}

Well 78, approximately $4,200 \mathrm{ft}$ south of the TRA wastewater infiltration ponds and $400 \mathrm{ft}$ northwest of the Big Lost River (fig. 1), is a monitoring well completed in perched ground water and has an open-hole interval from a depth of 66 to $204 \mathrm{ft}$. Geophysical logs indicate that minimal sedimentary interbed thicknesses are penetrated by the well.

Water-level changes in well 78 (fig. 4) clearly are correlated to streamflow infiltration in the Big Lost River reach from the INEEL Diversion to Lincoln Boulevard. Extended periods of streamflow infiltration were accompanied by water-level rises of as much as $100 \mathrm{ft}$ in well 78; periods of decreasing infiltration were accompanied by a corresponding recession in the water level in the well.

Water-chemistry data (dissolved-solids concentrations, tritium concentrations, and chromium concentrations) indicate that well 78 is not monitoring water from the TRA perched ground-water zones. Water-chemistry data and correlation of water levels to streamflow infiltration indicate that an extensive perched ground-water zone exists beneath the channel of the Big Lost River during periods of surface-water flow.
Robertson and others (1974, p. 99-101) noted that water levels in three monitoring wells in the perched-water zone also fluctuated intermittently in response to flow in the Big Lost River. Wells 66, 71 , and 62 are $1,400 \mathrm{ft}, 1,900 \mathrm{ft}$, and $2,500 \mathrm{ft}$, respectively, from the river channel. Comparison of hydrographs of water levels in these wells with monthly streamflow records at Lincoln Boulevard during 1965-94 indicates a correlation of waterlevel rises to short-term peaks in flow (fig. 4). Such peaks occurred in June and July 1965, and May, June, and July 1969. These water-level rises corresponded to monthly discharges that were in excess of 20,000 acre-ft. Water-level trends subsequent to these peaks characteristically resembled a flowrecession curve. After the cold-waste ponds were constructed and disposal began in 1982, waterlevel changes in wells 62 and 71 occurred not only in response to surface-water discharges exceeding 20,000 acre- $\mathrm{ft}$ per month but also in response to cold-waste pond disposal.

Well 66 monitored a perched water level that was affected by recharge from the Big Lost River. According to Robertson and others (1974, p. 101), peak flows in the river were reflected in water levels in well 66 after a delay of 4 to 5 months. The water level in well 66 declined in response to theextended period of no flow from 1977 to 1981 . Modifications were made to this well in 1986 and subsequent water levels represented water moving from a shallow, perched water body and out of the casing through perforations at a depth of $218 \mathrm{ft}$.

\section{NUMERICAL SIMULATION OF PERCHED GROUND-WATER FLOW}

Numerical simulations were used to evaluate the conceptual model of perched ground-water flow through the basalts and sediments in the upper $200 \mathrm{ft}$ of the unsaturated zone beneath the TRA and to refine estimates of hydraulic properties that control the formation of these perched ground-water zones. These simulations rely on certain assumptions. The modeling approach includes the determination of the effect that violations of these assumptions have on simulation of observed field parameters. 
Table 1. Well completion data, stratigraphic data, and model layers for wells completed in perched ground-water zones at the Test Reactor Area

[Well identifier: see figure 1 for location of wells; Row/column: model grid location corresponding to well; Production interval: casing interval, in feet below land surface, open to perched ground-water body; Altitude and simulated top/bottoms, in feet above sea level; Abbreviations: <, less than; DNP, did not penetrate; dpnd, deepened: RC, reconstructed in 1986; ----, not applicable]

\begin{tabular}{|c|c|c|c|c|c|c|c|c|c|c|}
\hline $\begin{array}{l}\text { Well } \\
\text { ident- } \\
\text { ifier }\end{array}$ & $\begin{array}{l}\text { Row/ } \\
\text { column }\end{array}$ & $\begin{array}{l}\text { Altitude } \\
\text { of land } \\
\text { surface }\end{array}$ & $\begin{array}{l}\text { Production } \\
\text { interval }\end{array}$ & $\begin{array}{l}\text { Altitude of } \\
\text { top } / \text { bottom of } \\
\text { the production } \\
\text { interval }\end{array}$ & $\begin{array}{l}\text { Simulated } \\
\text { top/bot. } \\
\text { tom of } \\
\text { layer } 2\end{array}$ & $\begin{array}{c}\text { Altitude of } \\
\text { top/bottom of } \\
\text { flow group } \\
\text { BC }\end{array}$ & $\begin{array}{l}\text { Simulated } \\
\text { top/bottom of } \\
\text { layer } 3\end{array}$ & $\begin{array}{c}\text { Altitude of } \\
\text { top/bottom } \\
\text { of flow group } \\
\text { DE1 }\end{array}$ & $\begin{array}{l}\text { Simulated } \\
\text { top/bottom } \\
\text { of layer } 4\end{array}$ & $\begin{array}{c}\text { Altitude of top/bot- } \\
\text { tom of combined flow } \\
\text { groups DE2, DE3 and } \\
\text { DE3-4 (W) }\end{array}$ \\
\hline 53 & $23 / 25$ & $4,923.46$ & $44-63$ & $4,879 / 4,860$ & $4,875 / 4,830$ & $4,880 / 4,836$ & $4,830 / 4.785$ & $4,836 /<4,834$ & $4,785 / 4,700$ & DNP \\
\hline 54 & $25 / 29$ & $4,921.60$ & $60-91$ & $\begin{array}{r}4,862 / 4,831 \\
\text { dpnd in } 1967\end{array}$ & $4,865 / 4,830$ & $4,862 /<4,831$ & $4,830 / 4,780$ & DNP & $4,780 / 4,700$ & DNP \\
\hline 55 & $20 / 32$ & $4,920.59$ & $45-81$ & $4,876 / 4,840$ & $4,865 / 4,825$ & $\begin{array}{l}4,878 /<4,862 \\
\text { dpnd to } 4,840\end{array}$ & $4,825 / 4,785$ & DNP & $4,785 / 4,700$ & DNP \\
\hline 56 & $18 / 30$ & $4,921.52$ & $59-80$ & $4,863 / 4,842$ & $4,875 / 4,825$ & $4,868 /<4,840$ & $4,825 / 4,790$ & DNP & $4,790 / 4,700$ & DNP \\
\hline 60 & $35 / 30$ & $4,919.11$ & $59-117$ & $4,860 / 4,802$ & $4,865 / 4,825$ & $4,859 / 4,828$ & $4,825 / 4,780$ & $4,828 /<4,816$ & $4,780 / 4,700$ & DNP \\
\hline 61 & $39 / 30$ & $4,922.86$ & $67-123$ & $4,856 / 4,800$ & $4,865 / 4,825$ & $4,862 / 4,829$ & $4,830 / 4,780$ & $4,829 /<4,806$ & $4,780 / 4,700$ & DNP \\
\hline 62 & $49 / 31$ & $4,922.33$ & $145-165$ & $4,777 / 4,757$ & $4,875 / 4,830$ & $4,871 / 4,832$ & $4,840 / 4,780$ & $4,832 / 4,772$ & $4,780 / 4,700$ & $4,772 /<4,759$ \\
\hline 63 & $26 / 17$ & $4,924.69$ & $62-109$ & $4,863 / 4,828$ & $4,865 / 4,840$ & $4,869 / 4,839$ & $4,840 / 4,780$ & $4,839 /<4,829$ & $4,780 / 4,700$ & DNP \\
\hline 64 & $23 / 41$ & $4,913.98$ & $186-205$ & $4,728 / 4,709$ & $4,875 / 4,830$ & $4,881 / 4,830$ & $4,830 / 4,780$ & $4,830 / 4,785$ & $4,780 / 4,700$ & $4,785 / 4,740$ \\
\hline 68 & $10 / 32$ & $4,917.04$ & $50-128$ & $4,867 / 4,789$ & $4,875 / 4,825$ & $4,876 / 4,827$ & $4,825 / 4,795$ & $4,827 /<4,793$ & $4,795 / 4,700$ & DNP \\
\hline 69 & $34 / 21$ & $4,924.47$ & $95-115$ & $4,829 / 4,809$ & $4,875 / 4,830$ & $4,874 / 4,823$ & $4,830 / 4,780$ & $4,823 /<4,809$ & $4,780 / 4,700$ & DNP \\
\hline 70 & $33 / 40$ & $4,917.77$ & $54-100$ & $4,864 / 4,818$ & $4,875 / 4,825$ & Not present & $4,825 / 4,775$ & Not present & $4,775 / 4,700$ & Not present \\
\hline 71 & $50 / 22$ & $4,924.64$ & $141-176$ & $4,865 / 4,741$ & $4,865 / 4,840$ & $4,870 / 4,840$ & $4,840 / 4,785$ & $4,840 / 4,788$ & $4,785 / 4,700$ & $4,788 /<4,741$ \\
\hline 72 & $5 / 30$ & $4,921.48$ & $\begin{array}{r}172-200 \\
\text { RC } 135-160\end{array}$ & $\begin{array}{r}4,749 / 4,721 \\
\mathrm{RC} 4,786 / 4,760\end{array}$ & $4,885 / 4,830$ & $4,885 / 4,835$ & $4,830 / 4,790$ & $4,835 / 4,781$ & $4,790 / 4,700$ & $4,781 /<4,721$ \\
\hline 73 & $14 / 13$ & $4,927.67$ & $62-127$ & $4,866 / 4,801$ & $4,875 / 4,840$ & $4,871 / 4,839$ & $4,840 / 4,785$ & $4,839 /<4,801$ & $4,785 / 4,700$ & DNP \\
\hline 74 & $6 / 10$ & $4,931.19$ & $32-192$ & $4,899 / 4,739$ & $4,895 / 4,845$ & Not present & $4,845 / 4,790$ & $4,897 / 4,786$ & $4,790 / 4,700$ & $4,786 / 4,737$ \\
\hline 75 & $44 / 42$ & $4,918.44$ & $175-212$ & $4,743 / 4,706$ & $4,875 / 4,825$ & Not present & $4,825 / 4,775$ & Not present & $4,775 / 4,700$ & Not present \\
\hline 78 & off grid & $4,933.08$ & $66-204$ & $4,867 / 4,729$ & --- & $4,866 / 4,837$ & --- & $4,837 / 4,767$ & $\cdots$ & $4,767 /<4,729$ \\
\hline 80 & $44 / 42$ & 4,917 & $43-204$ & $4,874 / 4,713$ & $4,875 / 4,825$ & Not present & $4,825 / 4,775$ & Not present & $4,775 / 4,700$ & Not present \\
\hline PW-7 & $30 / 9$ & $4,925.24$ & $200-225$ & $4,725 / 4,700$ & $4,875 / 4,845$ & $4,871 / 4,832$ & $4,845 / 4,775$ & $4,845 / 4,775$ & $4,775 / 4,700$ & $4,775 / 4,690$ \\
\hline PW-8 & $35 / 30$ & $4,918.56$ & $145-165$ & $4,774 / 4,754$ & $4,865 / 4,825$ & $4,871 / 4,832$ & $4,825 / 4,780$ & $4,828 / 4,773$ & $4,780 / 4,700$ & $4,773 /<4,740$ \\
\hline PW-9 & $14 / 13$ & $4,926.91$ & $140-200$ & $4,787 / 4,727$ & $4,875 / 4,840$ & $4,871 / 4,832$ & $4,840 / 4,785$ & $4,847 / 4,782$ & $4,785 / 4,700$ & $4,782 /<4,726$ \\
\hline
\end{tabular}




\section{Approach}

The numerical modeling approach consisted of development and calibration of steady-state and transient flow models using the USGS Modular Ground-Water Flow Model (MODFLOW) (McDonald and Harbaugh, 1988). The numerical models developed in this study do not represent unique solutions.

The modular compartmentalization of the MODFLOW code facilitates the development of additional capabilities without modifying existing packages. The original Block-Centered Flow (BCF) Package did not permit the activation of previously inactive cells. However, the development of the BCF2 package (McDonald and others, 1991) provided a method to convert inactive cells to variable-head cells. This feature allowed the simulation of saturated flow through a perched water body in several layers through time beginning with only a few, minimally saturated, active cells. Simulations did not represent unsaturated flow properties related to changing moisture content. Input for the steady-state and transient models included data arrays to configure the model grid and layers, boundary conditions, saturated hydraulic properties, and recharge.

A recharge term was used to represent water moving through the unsaturated zone that would be available to recharge perched ground water. This term included wastewater leaking from wastewater infiltration ponds and streamflow infiltration in the Big Lost River. Areal recharge on the Snake River Plain in the vicinity of the TRA is a relatively small proportion of the recharge term and was disregarded in simulations. Steady-state and transient recharge input data are discussed in subsequent sections.

\section{Assumptions}

The MODFLOW code (McDonald and Harbaugh, 1988) simulates saturated ground-water flow in three dimensions through porous media by using the finite-difference method. Locally, the porous-media assumption is violated by the fracture-dominated matrix. However, for increased volumes, only the larger details of the flow system can be represented and a fracturedominated flow system is approximated by porous-media flow.

Porous-media models have been used to simulate regional and subregional flow in fractured basalts of the Snake River Plain aquifer (Robertson, 1974; Garabedian, 1992; Spinazola, 1994). At the scale of the TRA perched ground-water zones (several thousands of feet), the effect of the porous media assumption on fracture-flow simulation probably is minimal because spatial dimensions of fracture systems are several orders of magnitude smaller than the smallest cell dimensions.

\section{Three-Dimensional Ground-Water-Flow Model}

The process of numerically simulating threedimensional flow through perched ground-water zones required definition of hydraulic boundaries, spatial discretization and development of a model grid and layers, and estimation of the distribution of hydraulic properties of basalt and sedimentary interbeds. Initial estimates of hydraulic properties were evaluated and refined using a steady-state simulation. Transient three-dimensional flow was simulated using refined hydraulic property values and time-discretized recharge based on wastewater disposal rates. Sensitivity analyses were conducted on the transient simulation to evaluate the effect of reasonable ranges in hydraulic properties on simulation results.

\section{Model Grid and Boundary Conditions}

A four-layer model was used in the numerical simulations of the perched ground-water zones at the TRA. The model grid consisted of 46 columns and 75 rows with variable cell dimensions (fig. 7). The grid was aligned in a northwest-to-southeast direction along the major axis of the known extent of perched ground water. Point of origin (southwest grid corner) was at latitude 43⒊'11" and longitude $112^{\circ} 58^{\prime} 27^{\prime \prime}$. The Transverse Mercator projection system was used with a central meridian of $112^{\circ} 57^{\prime} 30^{\prime \prime}$. The grid was rotated $39^{\circ}$ counterclockwise from the central meridian. Cells in the area of interest were 100 by $100 \mathrm{ft}$ (fig. 7). Cell dimensions were increased up to $500 \mathrm{ft}$ toward the northeast, northwest, and southeast 
model boundaries (fig. 7). Cells are described in this report by row, column, and layer. The dimensions of the modeled area were 1.1 by $1.8 \mathrm{mi}$. The model simulated flow in the upper $200 \mathrm{ft}$ of the approximately $450 \mathrm{ft}$ of basalts and sediments overlying the Snake River Plain aquifer. The first layer represented surficial sediments, the second layer represented the BC flow group (Anderson, 1991, p. 17), the third layer represented the DE1 flow group, and the fourth layer represented the interbed unit associated with the DE2, DE3, and DE3-4(W) flow groups. A fifth layer with an assigned constant head below the top of the layer was used to remove downward flow from the model. Tops and bottoms of layers were assigned altitudes above sea level derived from contour maps of the bases and tops of basalt-flow groups (Anderson, 1991, figs. 12, 14, and 16).

The model grid was configured to extend beyond the observed limits of the TRA perched ground-water zones. Lateral no-flow boundaries on all four sides of the model do not represent natural conditions as indicated by stratigraphic data. However, no-flow boundaries were used because no indication exists that the perchedwater zones extended to these artificial boundaries during the simulation period. The scope of this analysis does not include predictive simulations that simulated extension of the perched ground-water zones near no-flow boundaries. The lateral no-flow boundary on the southeastern side of the model was used to simulate one half of a ground-water divide beneath the Big Lost River. Streamflow infiltration from the Big Lost River was represented by recharge to uppermost active southeastern boundary cells of the model grid (fig. 7).

\section{Steady-State Estimation of Hydraulic Properties}

Numerical simulation input data that represented hydraulic properties included horizontal hydraulic conductivity, vertical conductance terms, and estimates of the storage coefficient. Initial estimates were based on reasonable values as presented in the conceptual model.

A steady-state model of the TRA perched ground-water zones was constructed from initial estimates of hydraulic properties and recharge to refine reasonable estimates of horizontal and vertical hydraulic conductivity of the basalts and the interbed unit. Although steady-state flow conditions within the perched ground-water zones have not been achieved because of the highly variable rate of wastewater disposal and historical changes in the places of disposal, an approximation of steady-state conditions was simulated using an average recharge to represent a period of relatively small fluctuations in wastewater disposal to the ponds. Recharge for the steady-state analysis was approximated using the mean rate of disposal during 1982-90 (fig. 3) to the cold-waste ponds, warm-waste ponds, chemical-waste pond, and sanitary-waste ponds because these disposal rates remained fairly constant through that period. Recharge from the Big Lost River was not considered in the steady-state simulation to simplify the solution.

Simulated steady-state water levels were compared with water levels measured in 1990 in wells completed in the perched ground-water zones (table 2). The differences between measured and simulated water levels ranged from 1.2 to $56.9 \mathrm{ft}$. These differences were attributed in part to the assumption of steady-state conditions in a dynamic flow system, to large vertical and horizontal hydraulic gradients in the perched groundwater zones, and to fracture flow anisotropy.

\section{Horizontal Hydraulic Conductivity}

Surficial sediments at the TRA are characterized by a large range in permeability. Because the distribution of permeability is not known, model layer 1 , used to simulate flow in the surficial sediments, was uniformly assigned a saturated hydraulic conductivity of $30 \mathrm{ft} / \mathrm{d}$. Model layer 2 was used to simulate flow in the BC flow group. On the basis of calibration of the steady-state model, a saturated hydraulic conductivity of 20 $\mathrm{ft} / \mathrm{d}$, within the range of estimated hydraulic conductivity for the BC flow group and approximating the median value ( $24 \mathrm{ft} / \mathrm{d}$ ), was uniformly assigned to all cells in layer 2. Model layer 3 was used to simulate flow within the DE1 flow group. On the basis of calibration of the steady-state model, a saturated hydraulic conductivity of 2 $\mathrm{ft} / \mathrm{d}$, at the lower end of the range of hydraulic conductivities estimated for the DE1 flow group, 
Table 2. Comparison of water levels in wells completed in perched ground-water zones at the Test Reactor Area (October 1990) and steady-state calibrated water levels for corresponding cells

[Well identifier: see figure 1 for location of wells; Row/column: model grid location corresponding to well; Model layer: layer corresponding to production interval of well; Altitude, in feet above sea level: --, not applicable]

\begin{tabular}{|c|c|c|c|c|c|}
\hline Well identifler & Row/column & Model layer & $\begin{array}{c}\text { Altitude of } \\
\text { measured water } \\
\text { level }\end{array}$ & $\begin{array}{c}\text { Altitude of } \\
\text { simulated steady- } \\
\text { state water level }\end{array}$ & $\begin{array}{c}\text { Difference between } \\
\text { measured and simu- } \\
\text { lated water level, in } \\
\text { feet }\end{array}$ \\
\hline 53 & $23 / 25$ & 2 & $4,860.7$ & $4,863.6$ & -2.9 \\
\hline 54 & $25 / 29$ & 2 & $4,861.6$ & $4,862.8$ & -1.2 \\
\hline 55 & $20 / 32$ & 2 & $4,860.6$ & $4,847.9$ & +12.7 \\
\hline 56 & $18 / 30$ & 2 & $4,859.5$ & $4,847.6$ & +11.9 \\
\hline 69 & $34 / 21$ & 3 & $4,856.6$ & $4,847.0$ & +9.6 \\
\hline 61 & $39 / 30$ & 3 & $4,843.7$ & $\begin{array}{l}4,846.0 \\
4,830.2\end{array}$ & $\begin{array}{l}-2.3 \\
+13.5\end{array}$ \\
\hline 63 & $26 / 17$ & 3 & $4,855.5$ & $\begin{array}{l}4,858.5 \\
4,841.3\end{array}$ & $\begin{array}{c}-3.0 \\
+14.2\end{array}$ \\
\hline 68 & $10 / 32$ & 3 & $4,861.3$ & $\begin{array}{l}4,837.5 \\
4,823.2\end{array}$ & $\begin{array}{l}+23.8 \\
+38.1\end{array}$ \\
\hline 70 & $33 / 40$ & 3 & $4,851.0$ & $4,857.1$ & -6.1 \\
\hline 60 & $35 / 30$ & 3 & $4,861.4$ & $\begin{array}{l}4,853.1 \\
4,838.3\end{array}$ & $\begin{array}{r}+8.3 \\
+23.1\end{array}$ \\
\hline 73 & $14 / 13$ & 3 & $4,848.0$ & $\begin{array}{c}\text { dry } \\
4,799.3\end{array}$ & $\begin{array}{r}-- \\
+48.7\end{array}$ \\
\hline 62 & $49 / 31$ & 4 & $4,792.2$ & $4,786.0$ & +6.2 \\
\hline 64 & $23 / 41$ & 4 & dry & $4,778.6$ & -- \\
\hline 72 & $5 / 30$ & 4 & $4,777.4$ & $4,799.5$ & -22.1 \\
\hline 71 & $50 / 22$ & 4 & $4,772.0$ & $\begin{array}{c}\text { dry } \\
4,791.4\end{array}$ & $-\overline{-19.4}$ \\
\hline 74 & $6 / 10$ & 4 & $4,746.5$ & $\begin{array}{l}\text { dry } \\
\text { dry }\end{array}$ & -- \\
\hline 80 & $44 / 42$ & 4 & dry & $\begin{array}{l}\text { dry } \\
\text { dry }\end{array}$ & -- \\
\hline PW-7 & $30 / 9$ & 4 & $4,727.4$ & $4,784.3$ & -56.9 \\
\hline PW-8 & $35 / 30$ & 4 & $4,858.0$ & $4,831.9$ & +26.1 \\
\hline PW-9 & $14 / 13$ & 4 & $4,757.7$ & $4,794.7$ & -37.0 \\
\hline
\end{tabular}

was uniformly assigned to all cells in layer 3. Model layer 4, used to simulate flow within the interbed unit, was uniformly assigned a saturated hydraulic conductivity of $0.05 \mathrm{ft} / \mathrm{d}$.

Model layer 5 was assigned a constant head that was lower than the bottom of layer 4 to provide a mechanism for removal of flow without affecting flow in the overlying layers. This layer did not simulate actual unsaturated flow conditions underlying the interbed unit.

\section{Vertical Hydraulic Conductance}

Vertical conductance terms were used to simulate the capability of the rock to transmit water vertically between layer 1 (surficial sediments) and layer 2 (basalt-flow group BC), between layer 2 and layer 3 (basalt-flow group DE1), between layer 3 and layer 4 (interbed unit associated with the DE2, DE3, and DE3-4(W) basaltflow groups), and between layer 4 (the interbed unit that serves as the perching mechanism for 


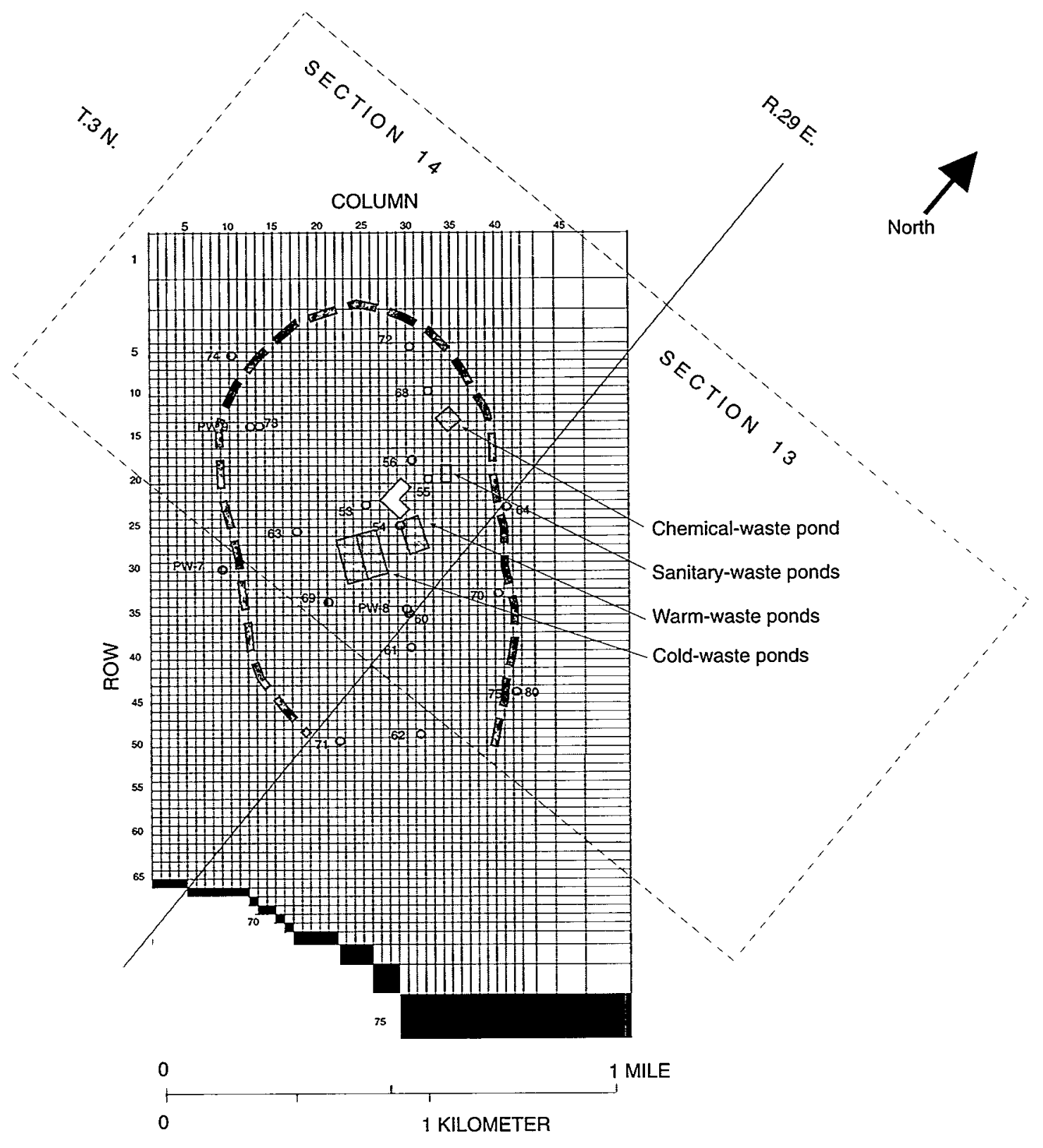

EXPLANATION

$\square$ APPROXIMATE EXTENT OF DEEP PERCHED WATER

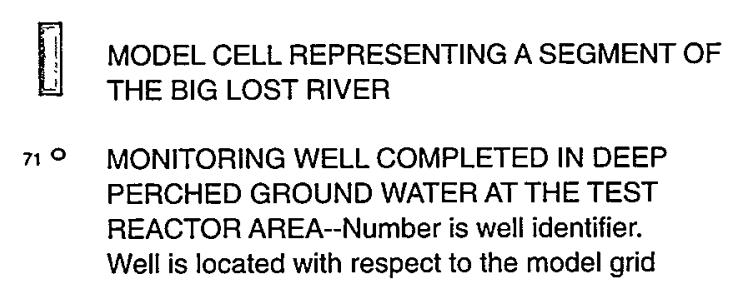

Figure 7.- Finite-difference grid, infiltration-pond cells, river cells, and layers used to simulate formation of perched ground-water zones at the Test Reactor Area. 


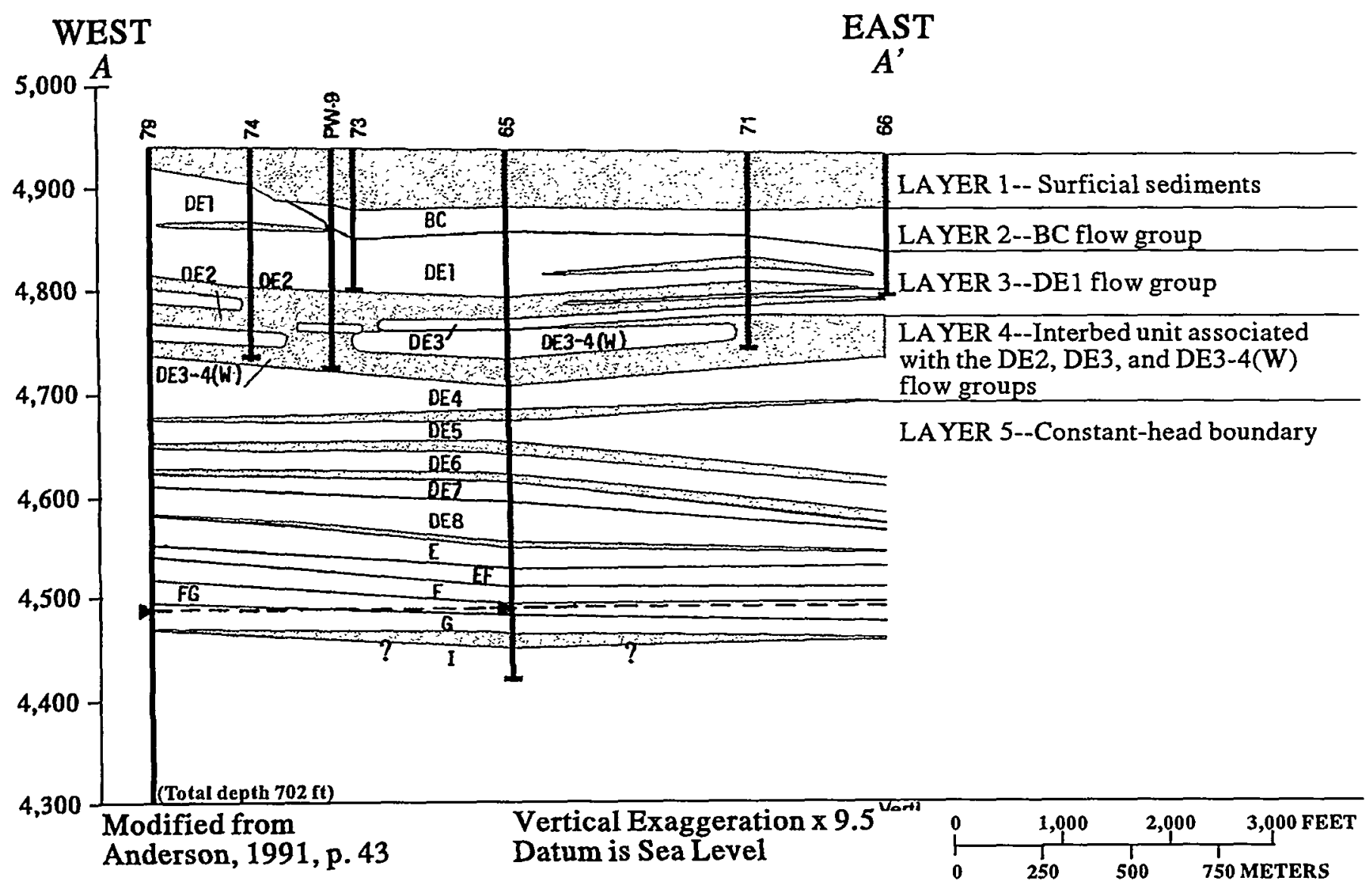

EXPLANATION

BASALT-Basalt-flow group composed of
one or more related flows. Letter, B, indicates
sequence of group from top to bottom of
section. Locally includes cinders and thin
layers of sediment
$\begin{aligned} & \text { CLAY, SILT, SAND, AND GRAVEL, - Major } \\ & \text { sedimentary interbed between basalt-flow } \\ & \text { groups. Locally includes cinders and basalt } \\ & \text { rubble }\end{aligned}$

Figure 7.-Finite-difference grid, infiltration-pond cells, river cells, and layers used to simulate formation of perched ground-water zones at the Test Reactor Area-continued. 
deep perched ground water at the TRA) and layer 5. The vertical conductance term between layers 4 and 5 was dominated by the vertical hydraulic conductivity of the interbed unit. Vertical conductance is a parameter that incorporates the thickness and vertical hydraulic conductivity of each of the stratigraphic units. Initially, the vertical hydraulic conductivity of the basalts and sediments was estimated to be two to three orders of magnitude less than the horizontal hydraulic conductivity because of the layered basalt-sediment stratigraphy.

The vertical conductance term used to simulate flow between the surficial sediments (layer 1) and the $\mathrm{BC}$ flow group (layer 2) incorporated estimates of the vertical hydraulic conductivity and thickness of the sediments and basalt. The calibrated vertical conductance term between layers 1 and 2 was $0.10 / d$. The vertical conductance terms used to simulate vertical flow between the $\mathrm{BC}$ flow group (layer 2) and the DE1 flow group (layer 3) and between the DE1 flow group (layer 3) and the interbed unit (layer 4) incorporated estimates of the vertical hydraulic conductivity and thickness of the basalts. Vertical conductance terms were assigned uniformly because little is known about the vertical hydraulic conductivity of the basalts except that it probably is at least several orders of magnitude smaller than the horizontal hydraulic conductivity. The calibrated vertical conductance term controlling flow between layers 2 and 3 was $0.018 / \mathrm{d}$. The calibrated vertical conductance term controlling flow between layers 3 and 4 was $0.0006 / d$.

The vertical conductance term used to simulate vertical flow between layer 4 (interbed unit) and layer 5 incorporated the vertical hydraulic conductivity and thickness of the sedimentary interbeds but neglected hydraulic properties and thickness of the underlying basalt. This approach was used because vertical flow between the interbed unit and underlying basalt is dominated by the small vertical hydraulic conductivity of the sedimentary interbeds relative to that of the basalt. In the numerical simulation, the vertical conductance term was calculated by dividing an estimated vertical hydraulic conductivity by the interbed thickness. The steady-state calibrated value for uniform vertical hydraulic conductivity was $0.0024 \mathrm{ft} / \mathrm{d}$, within the range of vertical hydraulic conductivity estimated by Robertson (1977, p. 26) for interbeds $(0.00001$ to $0.1 \mathrm{ft} / \mathrm{d})$ and smaller than the initial estimate $(0.006 \mathrm{ft} / \mathrm{d})$ made using total flux and approximate area of the perched ground-water zones.

A two-dimensional array (fig. 8) was constructed from the inverse of the line of equal interbed thickness (fig. 6). This array, multiplied by the calibrated vertical hydraulic conductivity estimate, was used as the vertical conductance term governing flow between layers 4 and 5 .

\section{Transient Calibration}

Input data for the transient simulation included horizontal hydraulic conductivity and vertical conductance arrays derived from the steady-state simulation. Input data also included estimates of effective porosity and the confined storage coefficient. Recharge from pond and stream infiltration was distributed using 43 oneyear stress periods to simulate the formation of the perched ground-water zones during 1952-94. Each stress period was divided into 4 time steps, with an initial time step of 51.4 days and a timestep multiplier of 1.4. Uncertainties introduced into the model that resulted from estimation of the hydraulic properties are discussed in the section on model sensitivity.

In the initial conditions for the transient model, all cells were dry with the exception of layer- 4 cells directly beneath infiltration ponds. These cells were given an initial head $1 \mathrm{ft}$ above the base of the layer because the MODFLOW method of converting no-flow cells to variablehead cells (McDonald and others, 1991) requires some initially active cells. In the process of model calibration, the vertical hydraulic conductivity and the storage coefficient were adjusted within reasonable ranges and numerical results were compared with measured hydraulic changes. The wetting threshold and the wetting factor, two parameters used in establishing an initial head in a previously dry cell, were adjusted to reduce model instabilities related to wetting and drying of cells. The wetting threshold, representing the head in a cell that would wet an adjacent or overlying cell, was adjusted to $20 \mathrm{ft}$ above the cell bottom for layers 1 through 3 , and $45 \mathrm{ft}$ for 

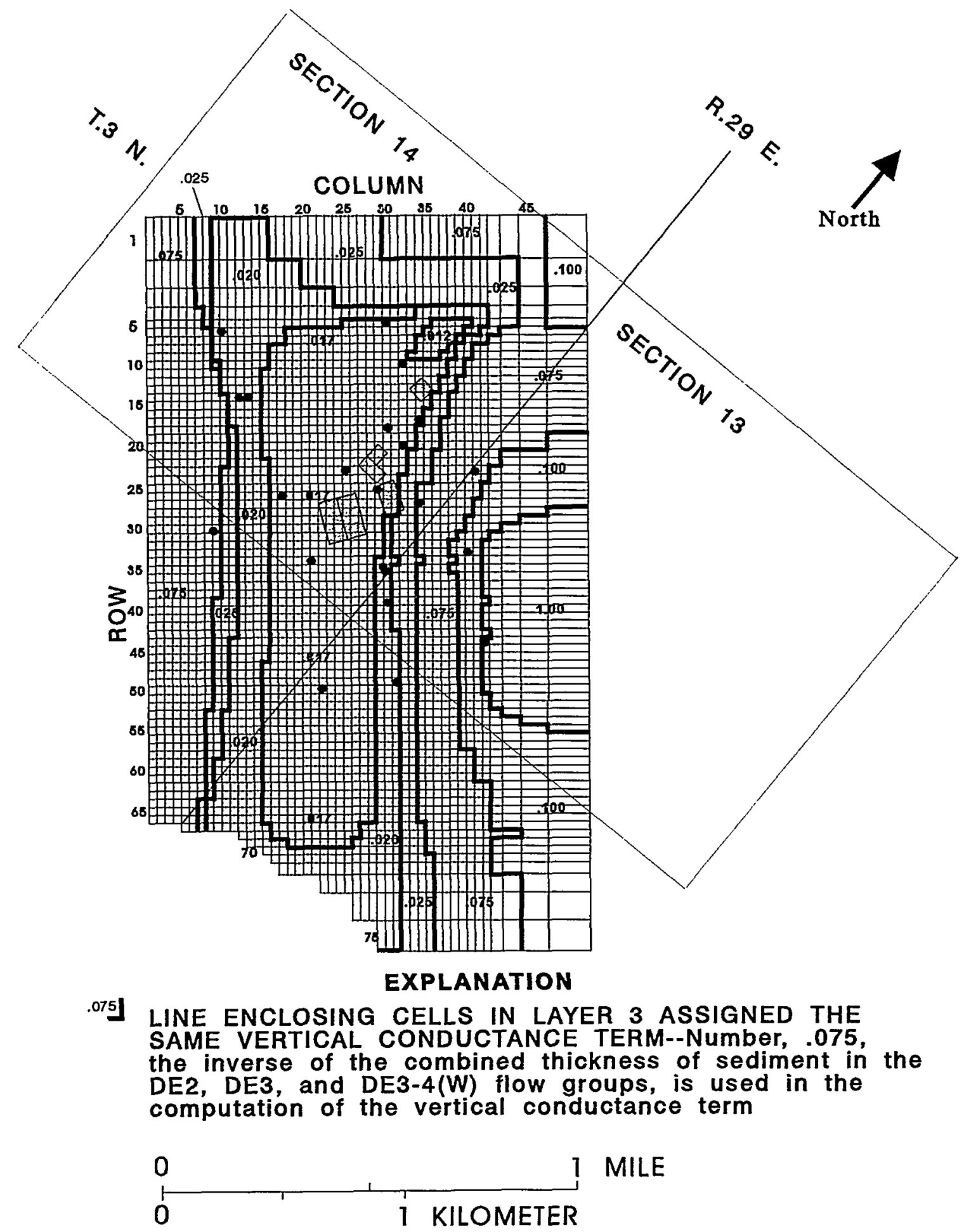

Figure 8.-Array of inverse sediment thickness used to simulate the vertical conductance of water through sedimentary interbeds associated with the DE2, DE3, and DE3-4(W) basalt-flow groups at the Test Reactor Area. 
layer 4 . The wetting factor, used with the wetting threshold to establish a starting head for a rewet cell, was adjusted to 0.18 .

The vertical hydraulic conductivity was adjusted to $0.0028 \mathrm{ft} /$ day. The effective porosity of basalt-flow groups at the TRA reasonably ranges from 5 to 20 percent. Areally, the storage coefficient can vary over the full range because of spatial variability in the number of vesicles, fractures, and interflow rubble zones. However, because distributions of these features are not well defined, storage coefficients were applied uniformly for each layer. An effective porosity of 10 percent, within the expected range for basalt of 5 to 20 percent, and a confined storage coefficient of 0.0001 , used to represent a fully saturated cell, were applied to all layers.

\section{Transient Recharge}

Transient recharge to the perched groundwater zones from infiltration pond wastewater leakage was characterized by daily and monthly fluctuations in response to wastewater disposal patterns. However, recharge from pond leakage was represented in the model by an average annual rate (fig. 3) because records for the 43 years of wastewater disposal do not provide the detailed information needed to describe these short-term fluctuations.

The wastewater recharge term was distributed among multiple cells to represent recharge from the warm-waste ponds, cold-waste ponds, chemical-waste pond, and sanitary-waste ponds (fig. 7). Recharge to individual cells was apportioned on the basis of the percentage of the pond area encompassed by the cell. The wastewater recharge term was applied to the uppermost active cell. Annual recharge to cell groups representing the TRA wastewater infiltration ponds in the transient simulation is shown on table 3 .

Recharge from the Big Lost River was based on estimates of streamflow infiltration derived from published and unpublished discharge records from selected stream-gaging stations. Discharge in the Big Lost River has been monitored downstream from the INEEL diversion and at the Lincoln Boulevard bridge since 1965 (Bennett, 1990, p. 44-45). Bennett (1990, p. 48) estimated streamflow infiltration for the reach between these stations. Estimated average annual streamflow infiltration from the INEEL diversion to Lincoln Boulevard from 1965 to 1988 was plotted against annual discharge for the Big Lost River downstream from Mackay Reservoir. This relation was used to approximate streamflow infiltration prior to 1965 based on discharge downstream from Mackay Reservoir. The relation assumed correlation between streamflow infiltration and discharge in the Big Lost River downstream from Mackay Reservoir but neglected variabilities introduced by the effect of diversions for irrigation between Mackay and Arco and by diversions to upstream spreading areas.

Model cells that represent river reaches formed the southeastern side of the model grid (fig. 7). Annual unit channel-length losses were estimated by dividing annual losses from the INEEL diversion to Lincoln Boulevard by the channel length. These annual estimates were multiplied by the reach lengths of the Big Lost River channel in each cell to obtain estimated annual recharge volumes. Recharge estimates were based on the assumption that losses were uniform between the diversion and Lincoln Boulevard. In actuality, this assumption probably is violated by variabilities in thickness of channel sediments and by localized ponding. These annual estimates also disregarded fluctuations in infiltration in response to the highly variable flows that occurred each year. Although actual losses probably were not uniform throughout the reach and were characterized by large fluctuations in response to changes in instantaneous discharge, estimated streamflow infiltration provided a reasonable long-term basis for modeling effects of recharge from the Big Lost River on perched ground water at the TRA.

In the transient simulation, recharge from annual estimated streamflow infiltration from the Big Lost River was halved along a no-flow boundary to represent the symmetry of model river-cell recharge. Annual simulated stream recharge estimates are shown in table 4 . The use of annual estimates did not adequately simulate shorter-term fluctuations and did not allow formation of a perched ground-water zone beneath 
Table 3. Volumes of recharge assigned to specified groups of model cells representing wastewater infiltration ponds at the Test Reactor Area, 1952-94

[Wastewater recharge in cubic feet per year; see footnote for recharge cell locations]

\begin{tabular}{|c|c|c|c|c|}
\hline Year & Warm-waste ponds ${ }^{1}$ & Cold-waste ponds ${ }^{2}$ & Chemical-waste pond ${ }^{3}$ & Sanitary-waste pond \\
\hline 1952 & 670,000 & 0 & 0 & $1,320,000$ \\
\hline 1953 & $2,010,000$ & 0 & 0 & $1,320,000$ \\
\hline 1954 & $12,700,000$ & 0 & 0 & $1,320,000$ \\
\hline 1955 & $13,100,000$ & 0 & 0 & $1,320,000$ \\
\hline 1956 & $12,570,000$ & 0 & 0 & $1,320,000$ \\
\hline 1957 & $13,770,000$ & 0 & 0 & $1,320,000$ \\
\hline 1958 & $33,290,000$ & 0 & 0 & $1,320,000$ \\
\hline 1959 & $26,740,000$ & 0 & 0 & $1,320,000$ \\
\hline 1960 & $29,550,000$ & 0 & 0 & $1,320,000$ \\
\hline 1961 & $31,420,000$ & 0 & 0 & $1,320,000$ \\
\hline 1962 & $37,830,000$ & 0 & $5,600,000$ & $1,320,000$ \\
\hline 1963 & $27,010,000$ & 0 & $5,600,000$ & $1,320,000$ \\
\hline 1964 & $22,990,000$ & 0 & $5,600,000$ & $1,320,000$ \\
\hline 1965 & $19,390,000$ & 0 & $5,600,000$ & $.1,320,000$ \\
\hline 1966 & $17,510,000$ & 0 & $5,600,000$ & $1,320,000$ \\
\hline 1967 & $24,200,000$ & 0 & $5,600,000$ & $1,320,000$ \\
\hline 1968 & $25,130,000$ & 0 & $5,600,000$ & $1,320,000$ \\
\hline 1969 & $35,560,000$ & 0 & $5,600,000$ & $1,320,000$ \\
\hline 1970 & $37,570,000$ & 0 & $5,600,000$ & $1,320,000$ \\
\hline 1971 & $29,280,000$ & 0 & $6,130,000$ & $1,240,000$ \\
\hline 1972 & $29,010,000$ & 0 & $9,730,000$ & $1,370,000$ \\
\hline 1973 & $35,960,000$ & 0 & $4,200,000$ & $1,250,000$ \\
\hline 1974 & $32,890,000$ & 0 & $4,190,000$ & $1,100,000$ \\
\hline 1975 & $29,410,000$ & 0 & $3,450,000$ & $1,000,000$ \\
\hline 1976 & $29,410,000$ & 0 & $3,540,000$ & $1,100,000$ \\
\hline 1977 & $19,650,000$ & 0 & $2,890,000$ & $1,240,000$ \\
\hline 1978 & $16,710,000$ & 0 & $2,790,000$ & $1,260,000$ \\
\hline 1979 & $9,760,000$ & 0 & $2,340,000$ & $1,170,000$ \\
\hline 1980 & $7,890,000$ & 0 & $1,560,000$ & $1,090,000$ \\
\hline 1981 & $7,350,000$ & 0 & $1,260,000$ & 770,000 \\
\hline 1982 & $6,860,000$ & $26,520,000$ & $1,190,000$ & 680,000 \\
\hline 1983 & $3,540,000$ & $32,140,000$ & 890,000 & 820,000 \\
\hline 1984 & $2,140,000$ & $33,240,000$ & 780,000 & 810,000 \\
\hline 1985 & $2,740,000$ & $29,730,000$ & 800,000 & 960,000 \\
\hline 1986 & $3,340,000$ & $36,430,000$ & 860,000 & $1,130,000$ \\
\hline 1987 & $2,530,000$ & $23,850,000$ & 730,000 & 910,000 \\
\hline 1988 & $2,450,000$ & $30,000,000$ & 560,000 & 990,000 \\
\hline 1989 & $2,580,000$ & $39,300,000$ & $1,030,000$ & $1,090,000$ \\
\hline
\end{tabular}


Table 3. Volumes of recharge assigned to specified groups of model cells representing wastewater infiltration ponds at the Test Reactor Area, 1952-94-Continued

\begin{tabular}{ccccc}
\hline Year & Warm-waste ponds $^{1}$ & Cold-waste ponds $^{2}$ & Chemical-waste pond $^{3}$ & Sanitary-waste pond $^{4}$ \\
\hline 1990 & $2,500,000$ & $34,000,000$ & $1,000,000$ & $1,150,000$ \\
1991 & $3,490,000$ & $27,570,000$ & $1,150,000$ & $1,750,000$ \\
1992 & $3,100,000$ & $19,170,000$ & $1,140,000$ & $1,680,000$ \\
1993 & $1,940,000$ & $33,420,000$ & 860,000 & $1,810,000$ \\
1994 & 0 & $28,570,000$ & 810,000 & $4,460,000$ \\
\hline
\end{tabular}

Model cells (row-column) specified to represent wastewater infiltration ponds at the Test Reactor Area

${ }^{1}$ Warm-waste ponds

1952 pond cell -- 20-29, 21-28 through 21-30, 22-28 through 22-29

1957 pond cell -- 22-27, 23-27 through 23-30, 24-28 through 24-30

1964 pond cell -- 24-31, 25-29 through 25-31, 26-29 through 26-32

${ }^{2}$ Sanitary-waste ponds

Constructed in 1952 -- 15-34

${ }^{3}$ Chemical-waste pond

Constructed in 1962 -- 12-34 through 12-35, 13-33 through 13-36, 14-34 through 14-35

${ }^{4}$ Cold-waste ponds

Constructed in 1982 -- 26-24 through 26-26, $27-24$ through 27-27, 28-24 through 28-27, $29-24$ through 29-27, $30-24$ through $30-27,31-24$ through $31-27,32-24$

Table 4. Cumulative annual recharge assigned to cells representing the channel of the Big Lost River near the Test Reactor Area, 1952-94

[Streamflow infiltration in cubic feet per year]

\begin{tabular}{|c|c|c|c|c|c|}
\hline Year & $\begin{array}{l}\text { Estimated annual recharge } \\
\text { from streamflow infiltration }\end{array}$ & Year & $\begin{array}{l}\text { Estimated annual recharge } \\
\text { from streamflow infiltration }\end{array}$ & Year & $\begin{array}{l}\text { Estimated annual recharge } \\
\text { from streamflow infiltration }\end{array}$ \\
\hline 1952 & $24,670,000$ & 1967 & $30,643,000$ & 1982 & $28,670,000$ \\
\hline 1953 & $18,105,000$ & 1968 & $16,368,000$ & 1983 & $37,683,000$ \\
\hline 1954 & $15,390,000$ & 1969 & $30,845,000$ & 1984 & $39,429,000$ \\
\hline 1955 & $11,515,000$ & 1970 & $21,578,000$ & 1985 & $18,653,000$ \\
\hline 1956 & $22,434,000$ & 1971 & $27,310,000$ & 1986 & $26,556,000$ \\
\hline 1957 & $19,264,000$ & 1972 & $20,012,000$ & 1987 & $12,391,000$ \\
\hline 1958 & $24,775,000$ & 1973 & $15,000,000$ & 1988 & $8,924,000$ \\
\hline 1959 & $10,674,000$ & 1974 & $27,601,000$ & 1989 & 0 \\
\hline 1960 & $9,764,000$ & 1975 & $26,741,000$ & 1990 & 0 \\
\hline 1961 & $7,395,000$ & 1976 & $21,683,000$ & 1991 & 0 \\
\hline 1962 & $12,920,000$ & 1977 & $8,766,000$ & 1992 & 0 \\
\hline 1963 & $18,272,000$ & 1978 & $18,441,000$ & 1993 & 0 \\
\hline 1964 & $18,378,000$ & 1979 & $14,440,000$ & 1994 & 0 \\
\hline 1965 & $13,433,000$ & 1980 & $20,214,000$ & & \\
\hline 1966 & $9,859,000$ & 1981 & $20,939,000$ & & \\
\hline
\end{tabular}


the Big Lost River. Additional efforts were not made to simulate this perched ground-water zone because of the limited effect it had on perched ground water beneath the TRA.

Infiltration of excess landscape irrigation and leakage from wastewater distribution systems was ignored because it represented only a small percentage of total recharge and because of the difficulty in determining the amount and location of recharge. Both sources potentially could provide a source of recharge to the perched groundwater zones at the TRA.

\section{Volumetric Budget for the Transient Simulation}

The volumetric budget compared the volume of water entering the model as recharge and changes in storage with water moving out of the model as changes in storage and flux through the base of the interbed unit. A total of $1.2854 \times 10^{9}$ $\mathrm{ft}^{3}$ of water representing leakage from wastewater disposal ponds entered the model. This volume was 2 percent larger than the estimated volume of $1.261 \times 10^{9} \mathrm{ft}^{3}$ of water actually discharged. A total of $1.3067 \times 10^{8} \mathrm{ft}^{3}$ of water went into storage and $9.4366 \times 10^{7} \mathrm{ft}^{3}$ of water went out of storage during 1952-94, leaving $3.6304 \times 10^{7} \mathrm{ft}^{3}$ of water in storage at the end of 1994 . The $1.2491 \times 10^{9} \mathrm{ft}^{3}$ of water leaving the model to the constant head represented the flux through the bottom of the interbed unit.

The cumulative volumetric budget for the entire model at the end of stress period 43 (1994) was as follows:
Comparison Between Simulated Transient Water Levels and Measured Water Levels

Model results included simulating water-level changes with time. These transient results were compared with measured water-level changes to evaluate how closely the transient model simulated the formation of perched ground water at the TRA. Water-level changes measured during 1952-94 in 15 perched-water monitoring wells were compared with simulated water-level changes in corresponding cells in layers 2,3 , and 4 to evaluate the conceptual model of flow through the perched ground-water zones at the TRA. Layer-1 water-level changes were not compared with limited water-level data because the extent of perched ground water in the surficial sediment was limited. Annually fluctuating rates of discharge to the warm-waste and cold-waste ponds affected water levels in wells. Several multiple-year periods showing clear decreases or increases in discharge (fig. 3) were used for water-level comparison. These periods included 1962-66, when annual discharge to the warmwaste ponds decreased from 37.8 million to 17.5 million $\mathrm{ft}^{3}$ of wastewater, 1966-70, when annual warm-waste pond discharge rates increased from 17.5 million to 37.6 million $\mathrm{ft}^{3}$, and 1973-79, when annual warm-waste pond discharge decreased from 36 million to 9.8 million $\mathrm{ft}^{3}$. Discharge to the cold-waste ponds began in 1982 . During 1986-87, annual discharge to the coldwaste ponds decreased from 36.4 million to 23.8 million $\mathrm{ft}^{3}$. During 1987-89, annual cold-waste pond discharge increased from 23.8 million to 39.3 million $\mathrm{ft}^{3}$. Use of annual discharge rates in the simulation did not represent large fluctuations in discharge that took place throughout each year. Because of this, simulated water-level changes

CUMULATIVE VOLUMES, IN CUBIC FEET

IN:

$$
\text { Storage }=9.4366 \times 10^{7}
$$

Pond recharge $=1.2854 \times 10^{9}$

Total in $=1.3798 \times 10^{9}$

In - Out $=-39,296$
OUT:

$$
\begin{aligned}
& \text { Storage }=1.3067 \times 10^{8} \\
& \text { Constant head }=\quad 1.2491 \times 10^{9}
\end{aligned}
$$

$$
\text { Total out }=1.3798 \times 10^{9}
$$

$\%$ Discrepancy $=0.00$ 
were compared both with the difference between maximum and minimum measured water levels and with end-of-year water-level changes.

Comparison between simulated layer- 2 water levels and water levels in wells completed in the $\mathrm{BC}$ flow group

Wells 53, 54, 55 and 56, all constructed in 1960 , were used to monitor water-level changes in the BC flow group. Simulated water levels in corresponding layer- 2 cells were graphically compared with measured water levels in these wells (fig. 9). The difference between measured and simulated end-of-year water levels was graphically presented with each hydrograph to further evaluate the capability of the model to simulate flow in perched ground water.

Cell 23-25-2 most closely approximated the completion interval for well 53, located between the warm-waste ponds and the cold-waste ponds, and completed in the upper part of the BC flow group. During the early 1960's, well 53 was used for wastewater disposal. This disposal was reflected in daily and monthly water-level fluctuations in wells 53 and 55 (fig. 9). In the model, an average annual recharge was used and these fluctuations were not represented in the transient simulation. Cell 25-29-2 most closely approximated the completion interval for well 54 , located adjacent to the southwest corner of the warm-waste pond cell constructed in 1957 and completed in most of the BC flow group. Cell 20-32-2 most nearly approximated the completion interval for well 55 , located north of the warm-waste ponds and completed in the upper half of the BC flow group. During 1960-63, the water level in this well fluctuated in response to wastewater injection in well 53 (fig. 9). Cell 18-30-2 most nearly approximated the completion interval for well 56 , located northwest of the warm-waste ponds and completed in the middle part of the BC flow group.

Measured water levels in wells 53,54,55, and 56 showed little response to changes in discharge to the warm-waste ponds during 1960-82. This lack of response indicated that the BC flow group was poorly connected to fracture systems carrying water from the warm-waste ponds. In contrast, simulated layer-2 water levels rose and declined in response to changes in discharge. As warm-waste pond discharge decreased after 1975 , simulated water levels declined and three of the four cells went dry.

Measured water levels in the wells completed in the $\mathrm{BC}$ flow group responded more directly to the cold-waste pond discharge, indicating that the well-completion intervals were hydraulically better connected to fracture systems carrying water from the cold-waste ponds. The three cells used to simulate water levels in wells 53,55 , and 56 rewetted in 1983 in response to discharge to the cold-waste ponds. Simulated water levels responded directly to changes in discharge to the cold-waste ponds.

The use of uniform hydraulic properties and of annual totals for wastewater discharge in the model did not accurately represent the anisotropy of the fractured system in the BC flow group and the effect of highly variable short-term discharges. As a result, water-level trends in the $\mathrm{BC}$ flow group were poorly to moderately approximated for the 43-year period. A more accurate representation of water levels in the $\mathrm{BC}$ flow group requires better understanding of the local distribution of horizontal and vertical hydraulic conductivity and the effective porosity of the fractured basalt and sediment composing the perched ground-water zones.

Comparison between simulated layer-3 water levels and water levels in wells completed in the DE1 flow group

Wells $60,61,63,68,69,70$, and 73 , all constructed in 1960 , were used to monitor waterlevel changes in the DE1 flow group or lateral depth equivalents. Simulated water levels in corresponding layer-3 cells were graphically compared with measured water levels in these wells (fig. 10).

Cell 35-30-3 most nearly approximated the completion interval for well 60 , located $500 \mathrm{ft}$ east of the cold-waste ponds and completed in the lower half of the $\mathrm{BC}$ flow group and the upper half of the DE1 flow group. Cell 39-30-3 most nearly approximated the completion interval for well 61 , located southeast of the cold-waste ponds and completed in the upper half of the DE1 flow group. Cell 26-17-3 most nearly approximated the completion interval for well 63 , located 


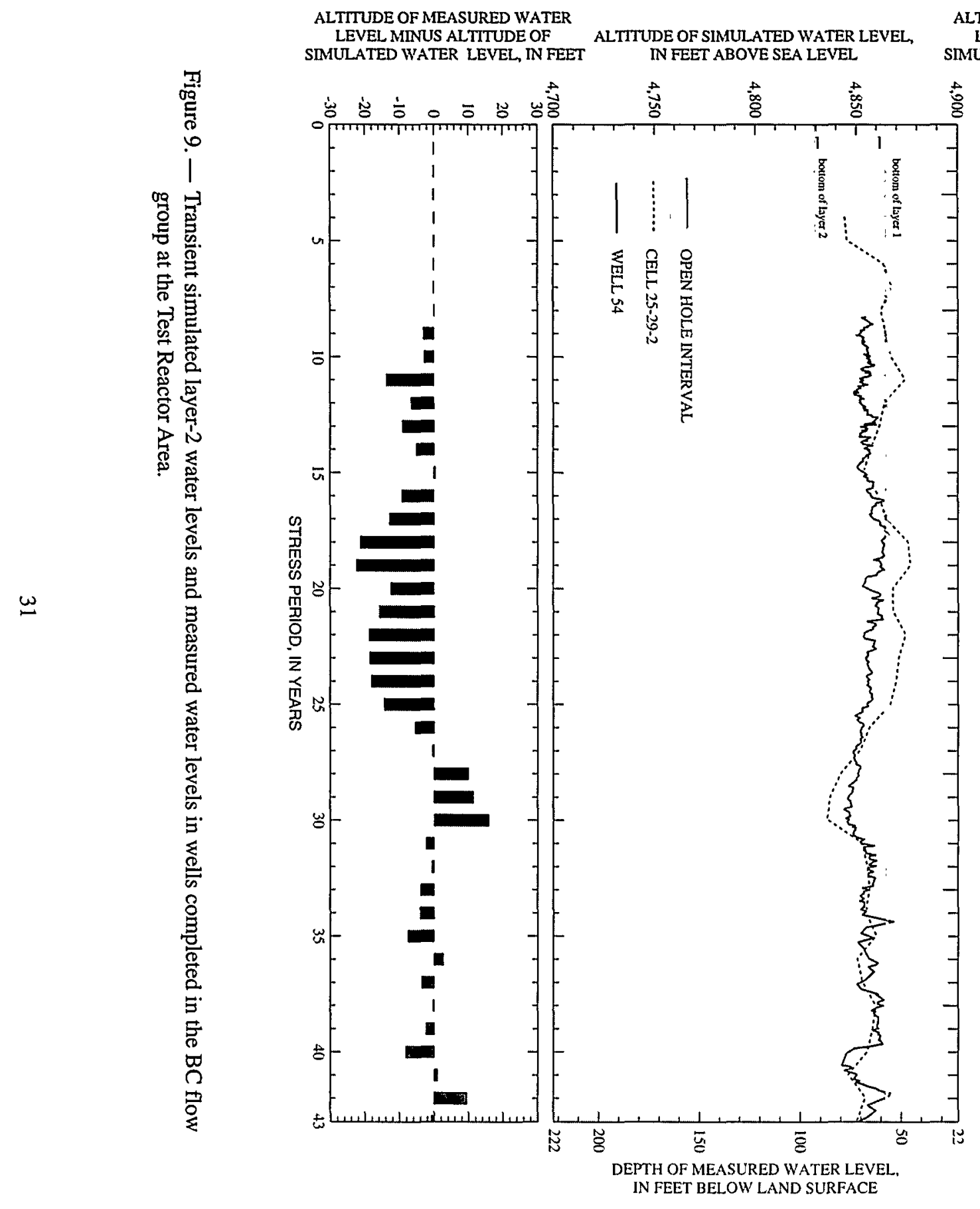

ALTITUDE OF MEASURED WATER LEVEL MINUS ALTITUDE OF MULATED WATER LEVEL, IN FEET

ALTITUDE OF SIMULATED WATER LEVEL.

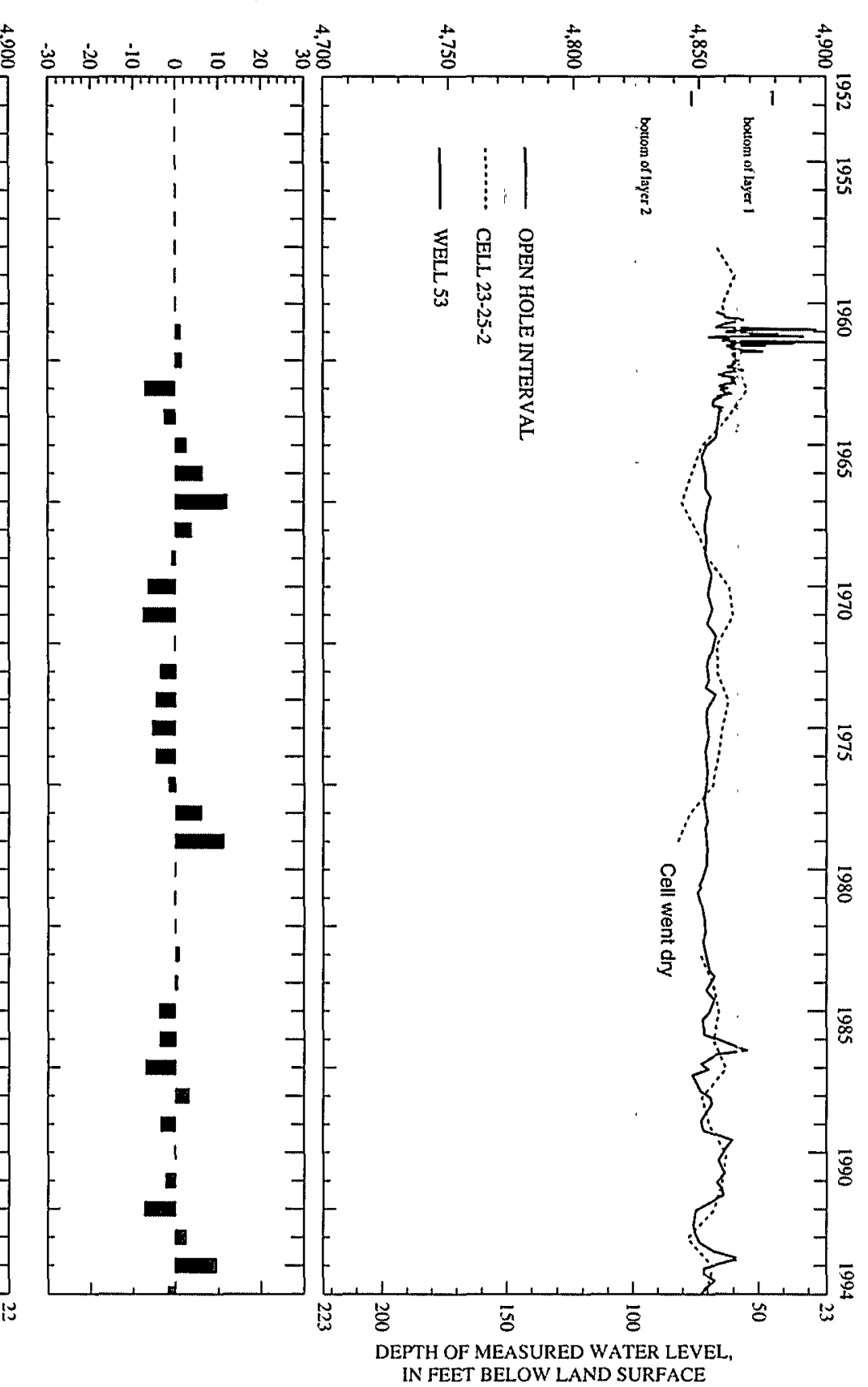




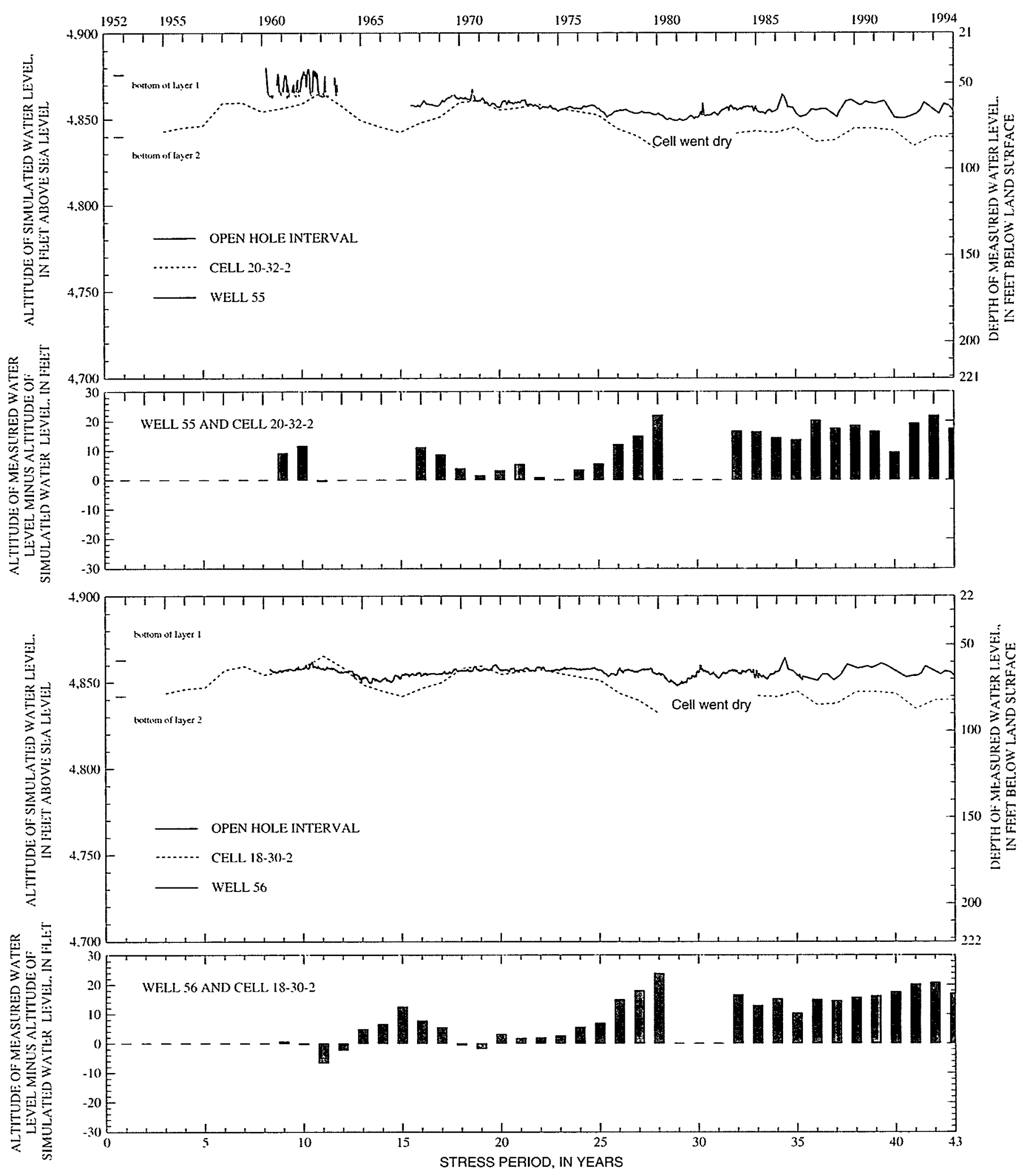

Figure 9. - Transient simulated layer-2 water levels and measured water levels in wells completed in the BC flow group at the Test Reactor Area—continued. 
approximately $400 \mathrm{ft}$ west of the cold-waste ponds and completed in the upper part of the DE1 flow group and the lower half of the $\mathrm{BC}$ flow group. Cell 10-32-3 most nearly approximated the completion interval for well 68 , located $400 \mathrm{ft}$ west of the chemical waste pond and completed over all of the DE1 flow group and the bottom half of the BC flow group. Cell 34-21-3 most nearly approximated the completion interval for well 69 , located south of the cold-waste ponds and completed in the upper part of the DE1 flow group. Cell 33-40-3 most nearly approximated the completion interval for well 70 , located $800 \mathrm{ft}$ east of the warm-waste ponds and completed in lateral equivalents to the lower half of the BC flow group and the upper half of the DE1 flow group where they pinch out against AEC Butte. Cell 14-13-3 most nearly approximated the completion interval for well 73 , located $1,500 \mathrm{ft}$ west of the warm-waste ponds and completed in the lower half of the $\mathrm{BC}$ flow group and the upper half of the DE1 flow group.

Simulated layer- 3 water levels were compared with water levels in seven wells completed in the DE1 flow group. Measured water levels responded to changes in wastewater discharge to the warm-waste and cold-waste ponds. For most of the wells, these changes were moderately to directly matched by simulated water-level changes. The water-level response in well 68 indicated that the DE1 flow group and associated interbeds to the north of the warm-waste ponds are characterized by small hydraulic conductivity. This response was not well represented because a uniform horizontal hydraulic conductivity was used throughout layer 3. Simulated water-level changes in cells representing wells to the west, southeast, and east of the warm-waste and coldwaste discharge ponds matched measured changes moderately well; large differences between measured and simulated water levels could be attributed to large hydraulic gradients near perched ground-water zone margins and to the cell location with respect to the location of the well.

Well PW-8, located about $30 \mathrm{ft}$ southwest of well 60, was drilled in 1986 and was completed in the interbed unit beneath the DE1 flow group. During 1986-94, the measured water level in well
PW-8 ranged from 0.2 to $4.9 \mathrm{ft}$ deeper than the water level in well 60 . The small water-level difference between the two wells indicates that the $\mathrm{PW}-8$ completion interval is hydraulically well connected to overlying units and that vertical flow is relatively continuous near the infiltration ponds.

Well PW-9, located about $90 \mathrm{ft}$ west of well 73 , was drilled in 1986 and was completed in the interbed unit. During 1986-95, the measured water level in well PW-9 was more than $80 \mathrm{ft}$ deeper than the water level in well 73. The large water-level difference between the two wells and the correspondence between the water level in well 73 and long-term wastewater discharge indicate that a unit vertical hydraulic gradient existed and that unsaturated flow occurred between perched water in the DE1 flow group and the interbed unit. This demonstrates that lateral flow in interflow rubble zones and limited vertical flow could occur at larger distances from recharge sources.

Comparison between simulated layer- 4 water levels and water levels in wells completed in the interbed unit

Wells $62,64,71,72$, and 74 , all constructed during 1960-61, and well PW-7, constructed in 1986 , were used to monitor water-level changes in the interbed unit. Simulated water levels in corresponding layer-4 cells were graphically compared with measured water levels in these wells (fig. 11).

Cell 49-31-4 most nearly approximated the well 62 completion interval, located $2,000 \mathrm{ft}$ southeast of the cold-waste ponds and completed in the upper part of the interbed unit and lower 5 $\mathrm{ft}$ of the DE1 basalt-flow group. Cell 23-41-4 most nearly approximated the completion interval for well 64 , located $800 \mathrm{ft}$ northeast of the warmwaste ponds and completed in the bottom part of the interbed unit. Cell 50-22-4 most nearly approximated the completion interval for well 71 , located $1,800 \mathrm{ft}$ southeast of the cold-waste ponds and completed in the upper part of the interbed unit. Cell 5-30-4 most nearly approximated the completion interval for well 72 , located $800 \mathrm{ft}$ northwest of the chemical-waste pond and $1,200 \mathrm{ft}$ northwest of the warm-waste ponds. 


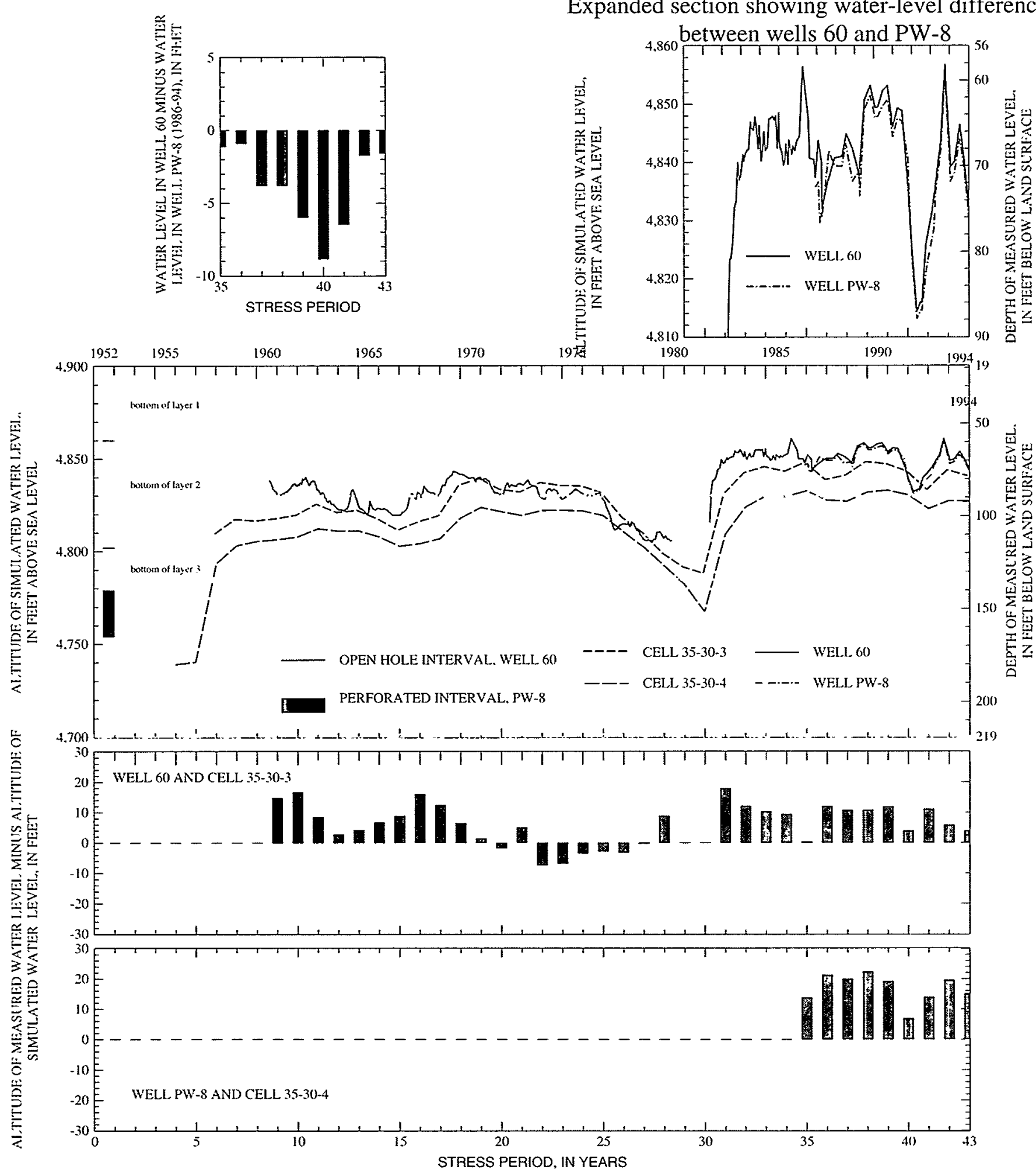

Expanded section showing water-level differences

Figure 10. - Transient simulated layer-3 water levels and measured water levels in wells completed in the DE1 flow group at the Test Reactor Area. 


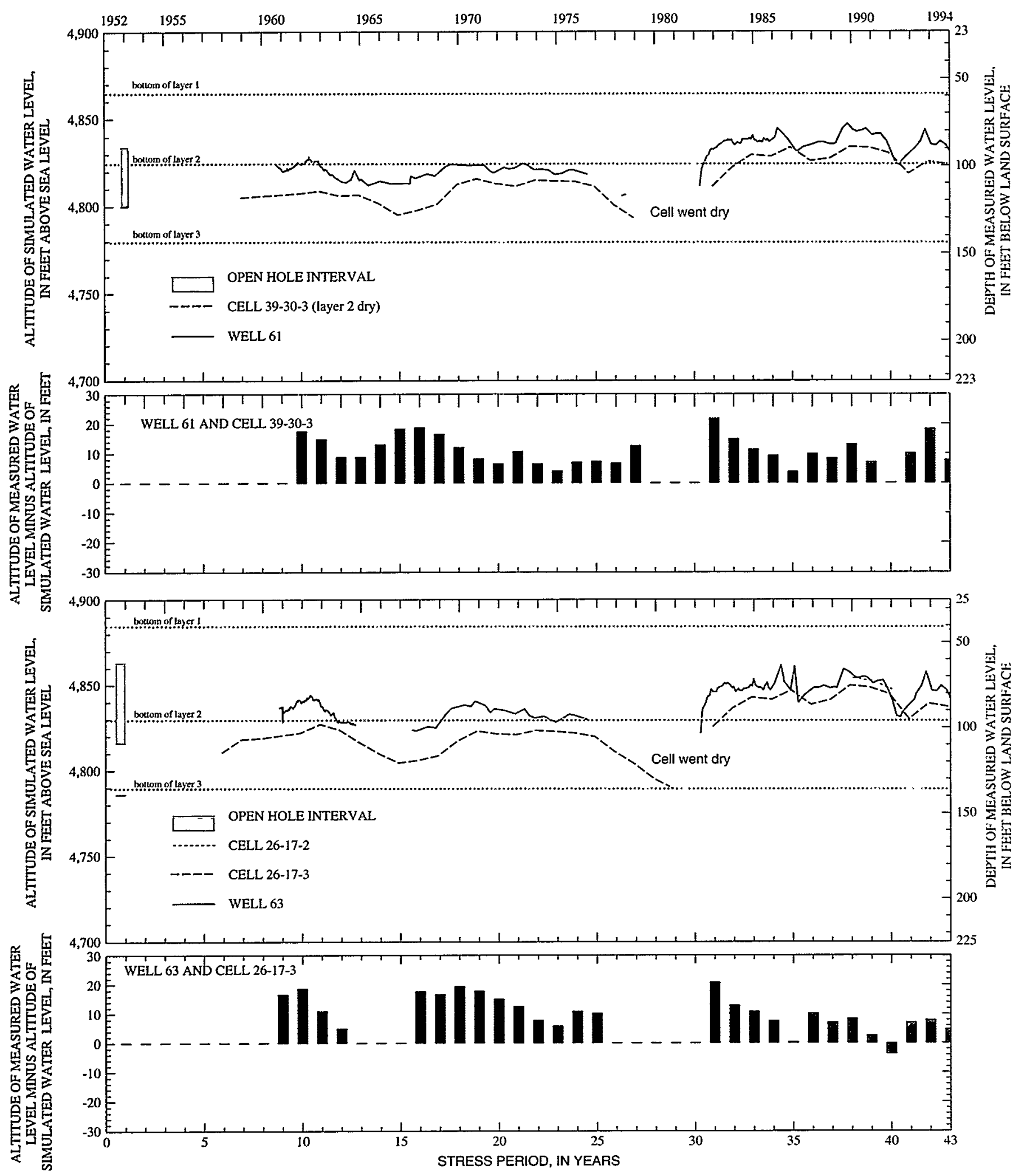

Figure 10. - Transient simulated layer-3 water levels and measured water levels in wells completed in the DE1 flow group at the Test Reactor Area-continued. 


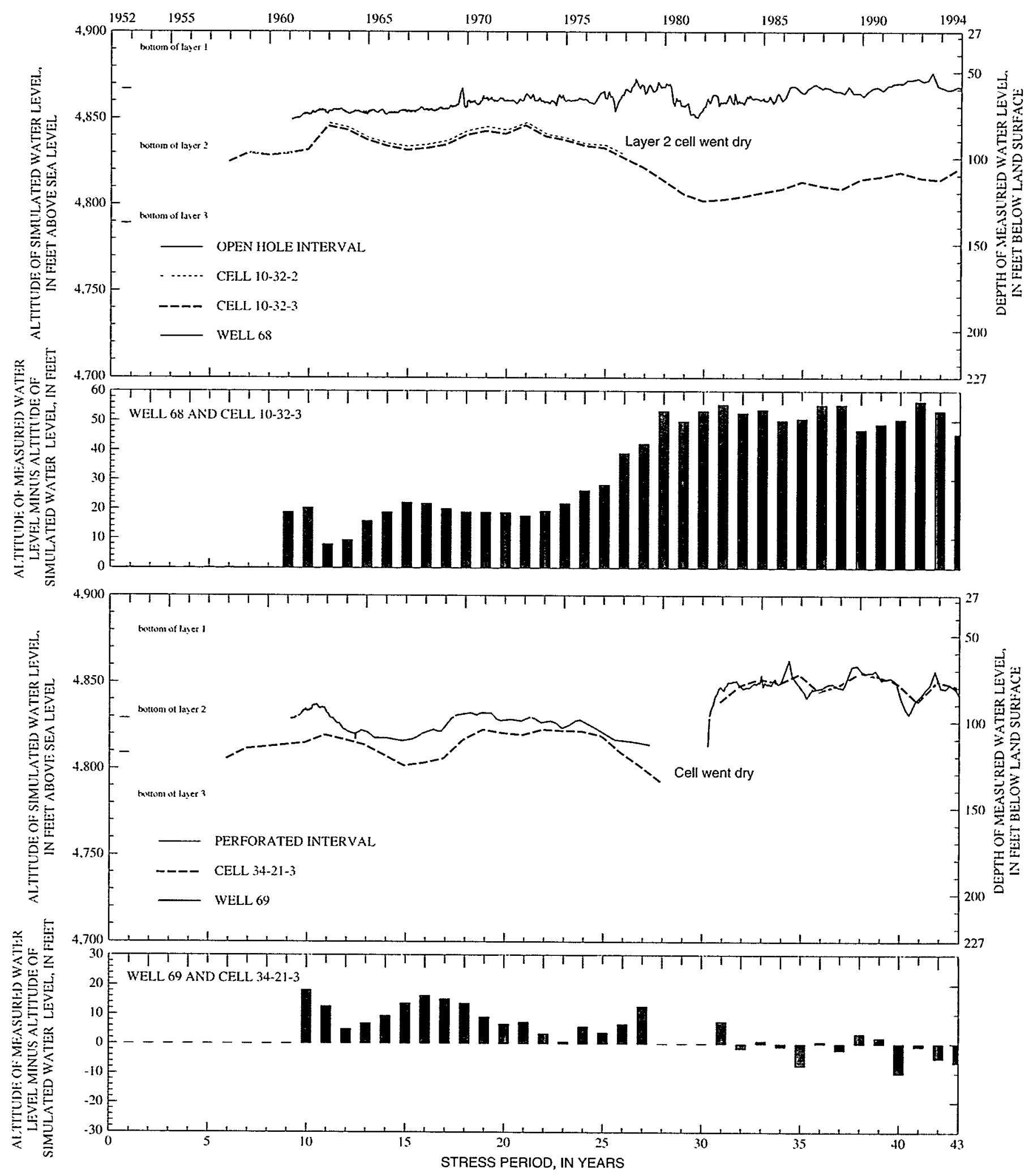

Figure 10. - Transient simulated layer-3 water levels and measured water levels in wells completed at the DE1 flow group at the Test Reactor Area-continued. 
ALTTTUDE OF SIMULATED WATER LEVEL NN FEET ABOVE SEA LEVEL

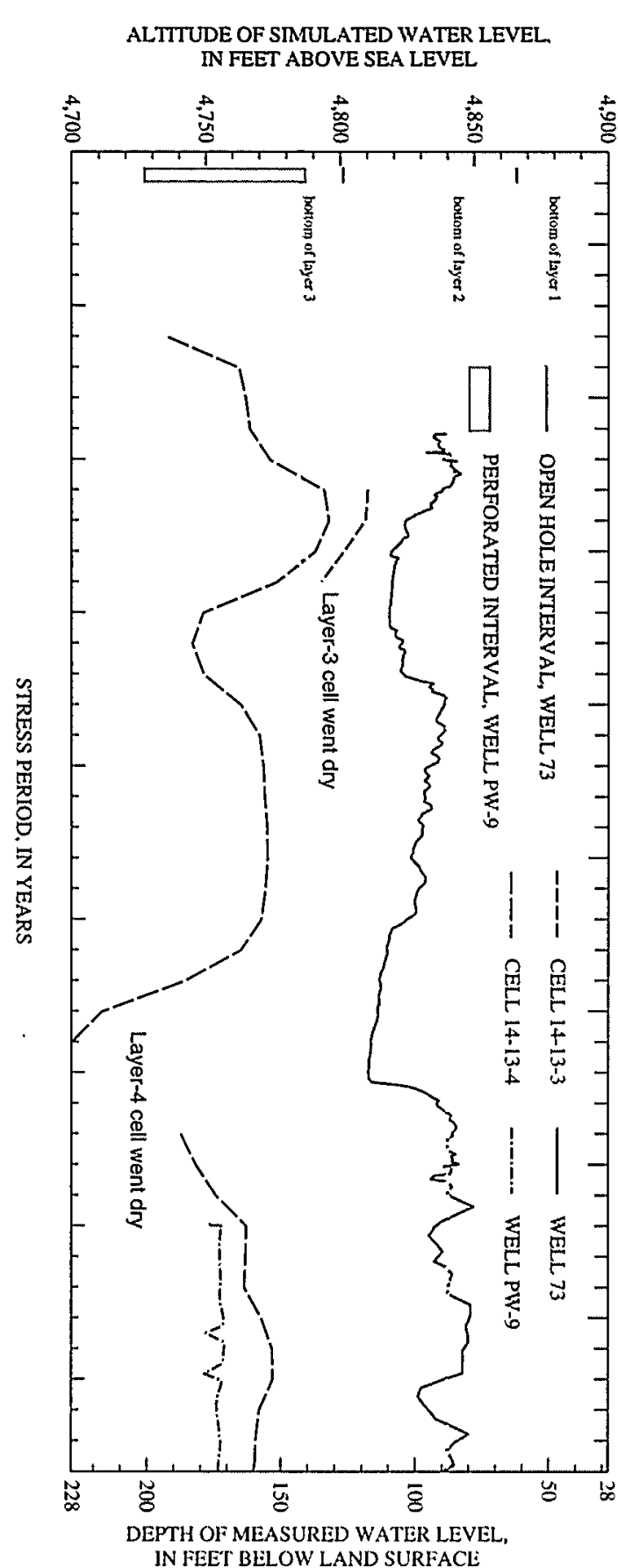

ALTITUDE OF MEASURED WATER

LEVEL MTNUS ALTITUDE OF ALTITUDE OF SIMULATED WATER LEVEL, SIMULATED WATER LEVEL. IN FEET IN FEET ABOVE SEA LEVEL

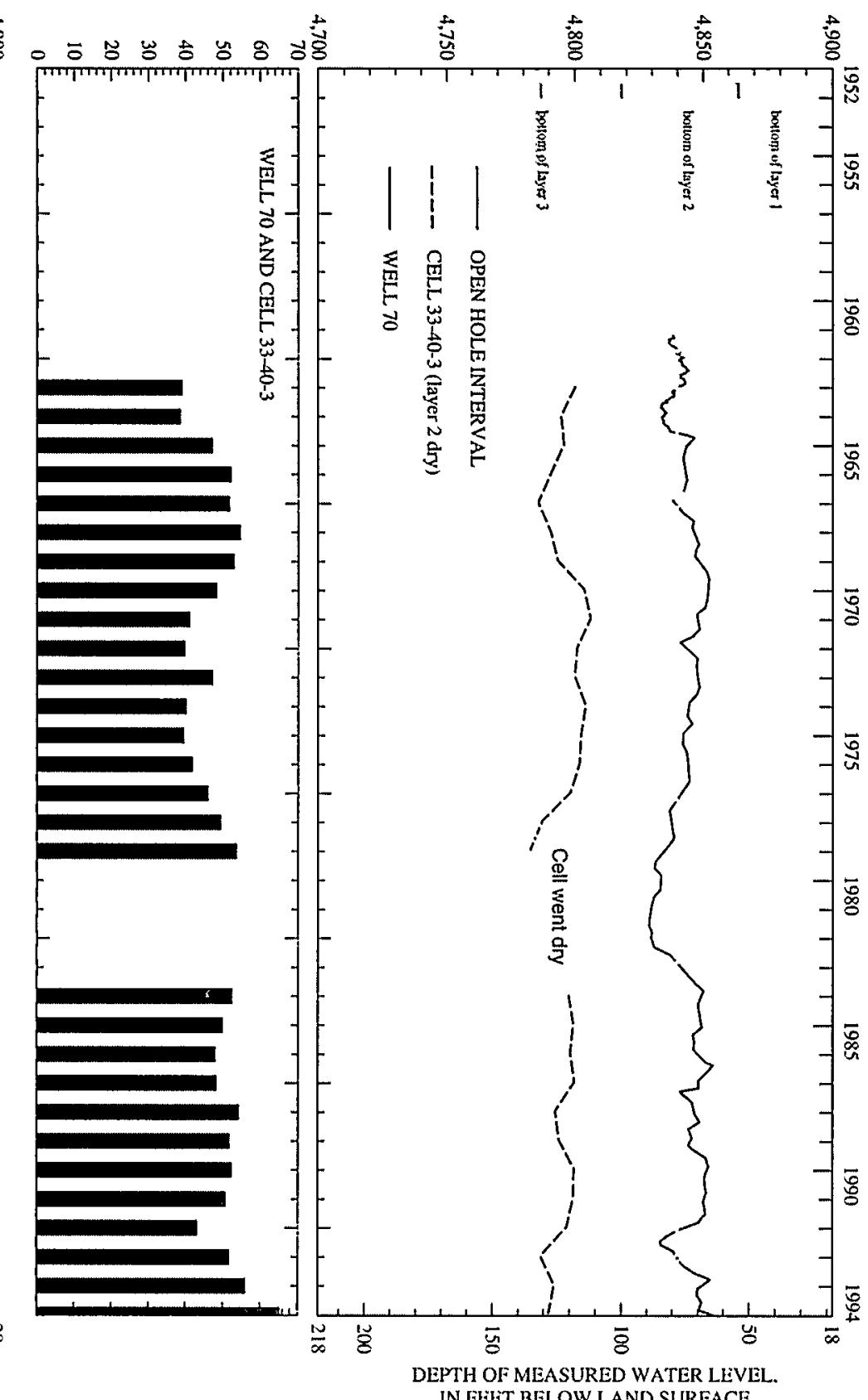


Cell 6-10-4 most nearly approximated the completion interval for well 74 , located $2,300 \mathrm{ft}$ west of the warm-waste ponds, and completed as open hole through the middle part of the interbed unit. Cell 30-9-4 most nearly approximated the completion interval for well PW-7, located $1,500 \mathrm{ft}$ southeast of the cold-waste ponds and completed in the lower third of the interbed unit.

Simulated layer- 4 water levels poorly matched water levels in six wells completed in the interbed unit. Simulation of measured water-level trends and extent of the perched ground-water zones was poor to fair. The inability of the model to adequately represent observed flow conditions in the interbed unit is attributed to several factors. First, all six wells were at or beyond the known extent of perched water, and water-level changes in response to wastewater discharge were greatly attenuated. Second, measured water levels indicated that a large vertical hydraulic gradient exists through the interbed unit. Well completion intervals were in either the upper or lower part of the unit and did not provide a water level representative of the entire flow group. Third, the effect of recharge from the Big Lost River was not represented well by using average annual recharge rates. Measured peaks in two wells indicated that the TRA perched ground-water zones mix with perched water beneath the Big Lost River when flow exceeds 20,000 acre-ft per month.

\section{Sensitivity Analysis}

Model input data were varied within acceptable ranges to determine how sensitive the model was to changes in different input variables. Sensitivity testing provided an assessment of the effect that hydraulic properties represented by specific input variables could have on simulated flow through the perched ground-water zones. Transient model response to input data variations was examined in four cells. Cell 23-25-2 was located next to the southwest corner of the warm-waste ponds and represented the completion interval for well 53. Cell 18-30-2 was located northwest of the warm-waste ponds and represented the completion interval for well 56. Cells 33-40-2 and 3340-3 were located near the eastern margin of the perched ground-water zones and represented the completion interval for well 70 . Cells 14-13-3 and 14-13-4 were located near the western margin of the perched ground-water zones and represented the completion interval for wells 73 and PW-9.

\section{Horizontal Hydraulic Conductivity}

Horizontal hydraulic conductivity was varied by \pm 40 percent, within the range estimated from aquifer-test data. In cells 23-25-2 and 18-30-2, decreased hydraulic conductivity increased simulated water levels by averages of 10.1 and $8.1 \mathrm{ft}$ during 35 and 37-year-long stress periods, respectively (fig. 12). Increased hydraulic conductivity decreased simulated water levels by an average of 5.2 and $3.7 \mathrm{ft}$, respectively. The matches between simulated water levels in layer 2 and water levels in well 53, close to warm-waste and cold-waste ponds, generally were not improved by increased or decreased hydraulic conductivity. Increased hydraulic conductivity did not improve the match between well 56 and cell 18-30-2; decreased hydraulic conductivity slightly improved the match. In cell 33-40-3, decreased hydraulic conductivity increased simulated water levels by an average of $2.6 \mathrm{ft}$ during 26 stress periods; increased hydraulic conductivity increased water levels by an average of $1.0 \mathrm{ft}$ during 29 stress periods. No significant improvement occurred in the match between measured and simulated water levels. Slight water-level decreases in response to decreased and increased hydraulic conductivity can be attributed to the cell's proximity to the perched ground-water zone margin. In cell 14-133 , water-level changes could be compared for only four stress periods. During that time, increased hydraulic conductivity did not significantly decrease water levels; decreased hydraulic conductivity increased water levels by an average of $5.5 \mathrm{ft}$ and the cell remained wet for 16 stress periods, improving the match between measured and simulated water levels. The water-level responses indicated that the model generally was more sensitive to decreases in hydraulic conductivity. The response of simulated water levels to these variations indicated that the distribution of horizontal hydraulic conductivity partially controls the size and shape of the perched groundwater zones at the TRA. 


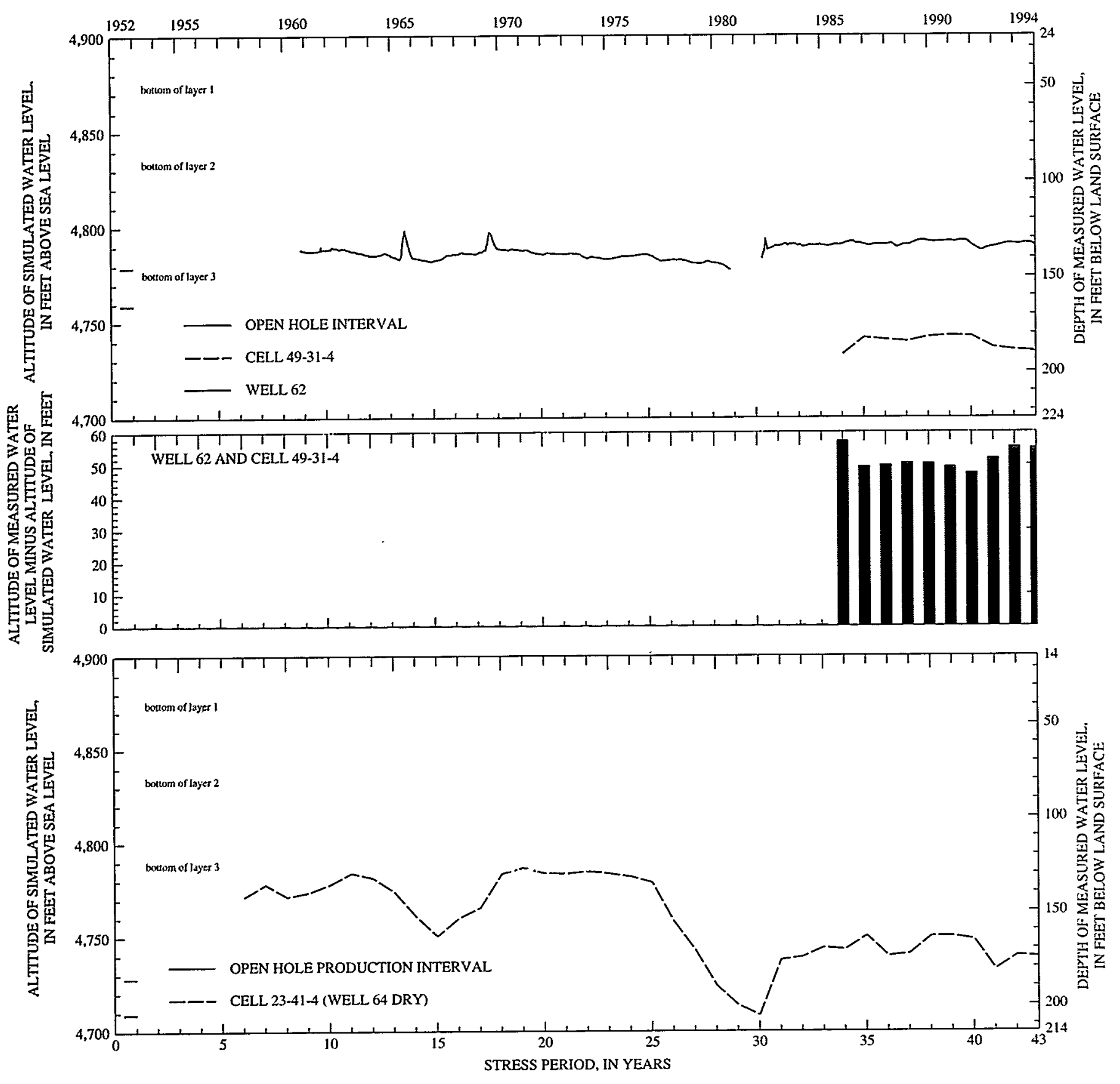

Figure 11. - Transient simulated layer-4 water levels and measured water levels in wells completed in the interbed unit at the Test Reactor Area. 


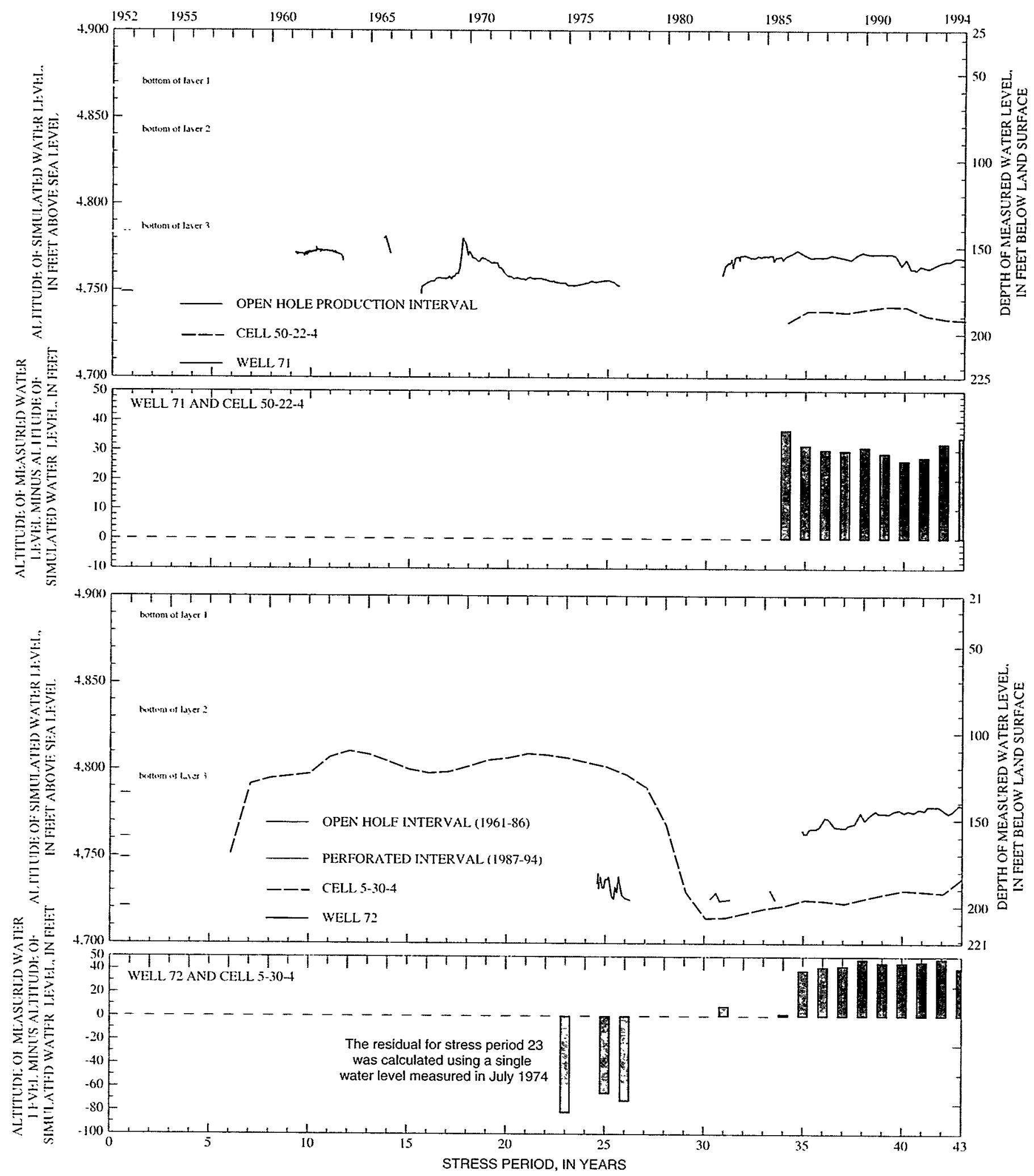

Figure 11. - Transient simulated layer-4 water levels and measured water levels in wells completed in the interbed unit at the Test Reactor Area-continued. 

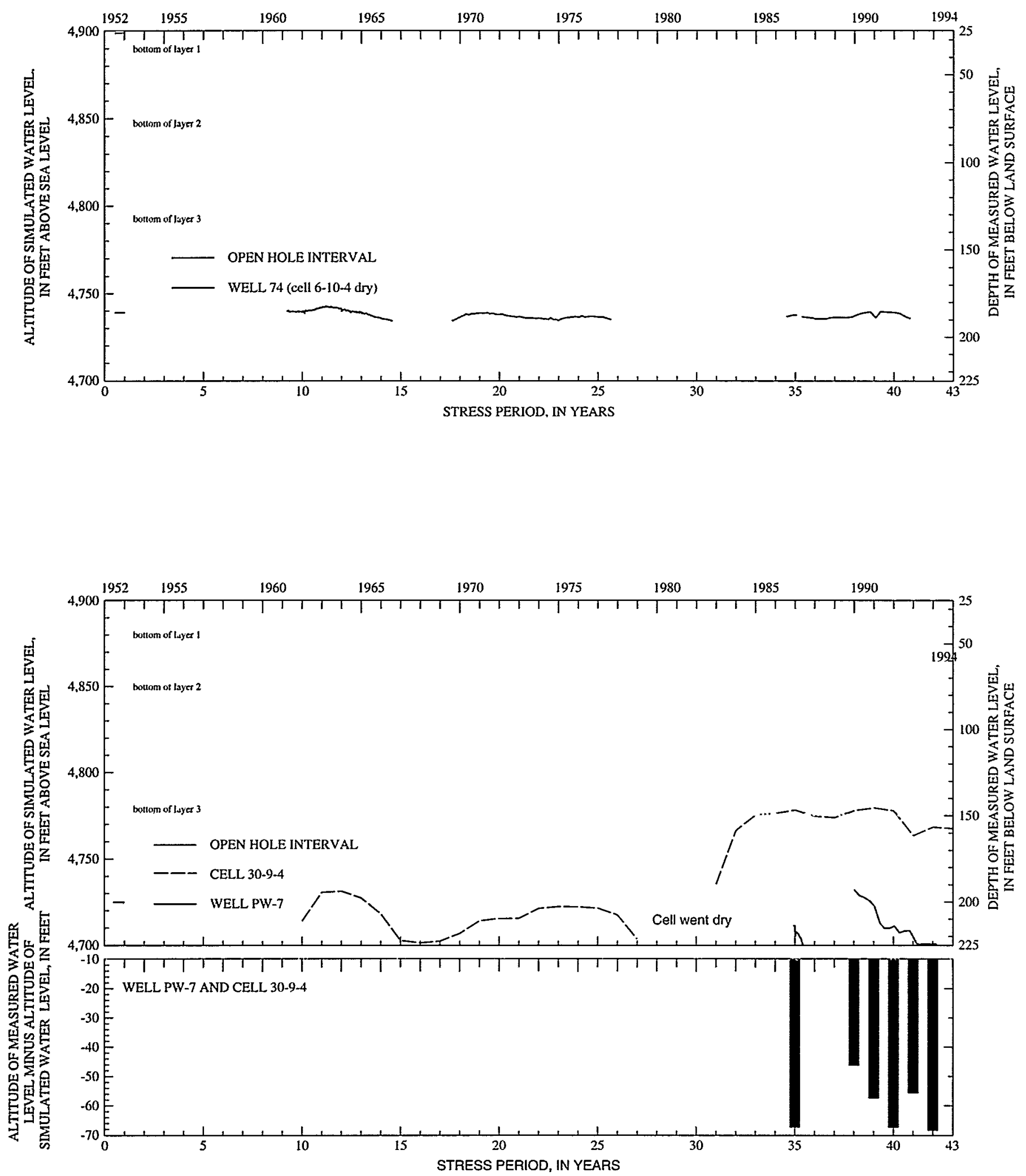

Figure 11.- Transient simulated layer-4 water levels and measured water levels in wells completed in the interbed unit at the Test Reactor Area—continued. 

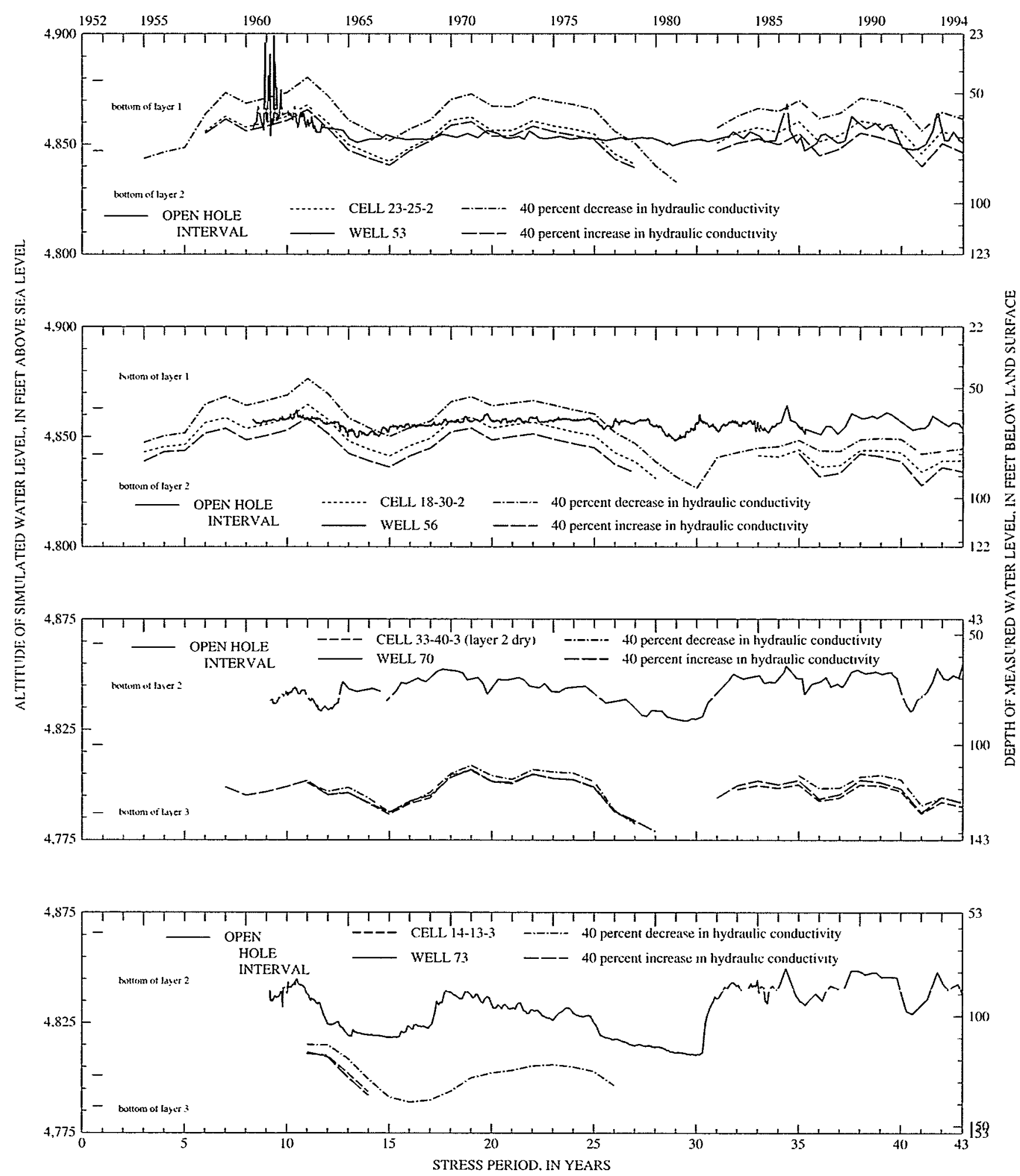

Figure 12. - Transient water levels at the Test Reactor Area simulated using \pm 40 -percent hydraulic conductivity, 1952-94. 


\begin{tabular}{ccccc}
\hline $\begin{array}{c}\text { Cell } \\
\text { (row- } \\
\text { column- } \\
\text { layer) }\end{array}$ & $\begin{array}{c}\text { 40-percent decrease in hydraulic conductivity } \\
\text { change from standard } \\
\text { simulation } \\
\text { (feet)/periods }\end{array}$ & $\begin{array}{c}\text { Range of water-level } \\
\text { changes (feet) }\end{array}$ & $\begin{array}{c}\text { 40-percent increase in hydraulic conductivity } \\
\text { Average water-level } \\
\text { change from standard } \\
\text { simulation } \\
\text { (feet)/periods }\end{array}$ & $\begin{array}{c}\text { Range of water-level } \\
\text { changes (feet) }\end{array}$ \\
$23-25-2$ & $+10.1 / 35$ & +7.2 to +12.4 & $-5.2 / 35$ & -6.7 to -3.7 \\
$18-30-2$ & $+8.1 / 37$ & +3.6 to +11.6 & $-3.7 / 34$ & -6.5 to 0 \\
$33-40-3$ & $+2.6 / 26$ & +0.2 to +5.8 & $+1.0 / 29$ & +0.1 to +2.3 \\
$14-13-3$ & $+5.5 / 4$ & +4.4 to +6.7 & $-0.65 / 4$ & -1.0 to +1.8 \\
\hline
\end{tabular}

\section{Vertical Hydraulic Conductivity}

Vertical hydraulic conductivity was varied by \pm 40 percent. These variations were within Robertson's (1977, p. 26) estimated range of vertical hydraulic conductivity. Simulated layer- 2 water levels generally were less sensitive to changes in vertical hydraulic conductivity than they were to changes in horizontal hydraulic conductivity (fig. 13). The average water-level change in cell 23$25-2$ ranged from +4.3 to $-2.8 \mathrm{ft}$ over 35 stress periods. No significant improvement occurred in the match between measured and simulated water levels in cell 18-30-2 by increasing or decreasing vertical hydraulic conductivity. In contrast, layer3 water levels were more sensitive to changes in vertical hydraulic conductivity. The average water-level change in cell 33-40-3 ranged from +14.0 to $-7.0 \mathrm{ft}$. For increased vertical hydraulic conductivity, the match was worsened for cells 33-40-3 and 14-13-3; for decreased vertical hydraulic conductivity, the match was improved for these cells. On the basis of these results, variations in vertical hydraulic conductivity can significantly affect water levels and the extent of perched water, particularly in lower layers.

\begin{tabular}{ccccc}
\hline $\begin{array}{c}\text { Cell } \\
\text { (row-column- } \\
\text { layer) }\end{array}$ & $\begin{array}{c}\text { Average water-level } \\
\text { change from standard } \\
\text { simulation } \\
\text { cfeet)/periods }\end{array}$ & $\begin{array}{c}\text { Range of water-level } \\
\text { changes (feet) }\end{array}$ & $\begin{array}{c}\text { Average water-level } \\
\text { change from standard } \\
\text { simulation } \\
\text { (feet)/periods }\end{array}$ & $\begin{array}{c}\text { Range of water-level } \\
\text { changes (feet) }\end{array}$ \\
$23-25-2$ & $+4.3 / 35$ & +2.4 to +5.3 & $-2.8 / 35$ & -4.0 to -1.8 \\
$18-30-2$ & $+4.8 / 37$ & +1.1 to +7.1 & $-3.1 / 25$ & -4.0 to -2.1 \\
$33-40-3$ & $+14.0 / 29$ & +5.0 to +18.8 & $-7.0 / 10$ & -7.9 to -4.7 \\
$14-13-3$ & $+10.2 / 4$ & +7.7 to +14.3 & remained dry & -- \\
\hline
\end{tabular}




\begin{tabular}{ccccc}
\hline $\begin{array}{c}\text { Cell } \\
\text { (row-column- } \\
\text { layer) }\end{array}$ & $\begin{array}{c}\text { 50-percent decrease in the storage coefficient } \\
\text { Average water-level } \\
\text { change from standard } \\
\text { simulation } \\
\text { (feet)/periods }\end{array}$ & $\begin{array}{c}\text { Range of water-level } \\
\text { changes (feet) }\end{array}$ & $\begin{array}{c}\text { Average water-level } \\
\text { change from standard } \\
\text { simulation } \\
\text { (feet)/periods }\end{array}$ & $\begin{array}{c}\text { Range of water-level } \\
\text { changes (feet) }\end{array}$ \\
$23-25-2$ & $-0.3 / 35$ & -2.6 to +2.6 & $+0.1 / 35$ & -1.6 to +1.9 \\
$18-30-2$ & $-0.5 / 37$ & -4.7 to +1.9 & $+0.3 / 35$ & -2.5 to +2.2 \\
$33-40-3$ & $+0.9 / 29$ & -4.2 to +2.8 & $+2.0 / 26$ & -1.7 to +4.7 \\
$14-13-3$ & $-3.5 / 3$ & -8.8 to +1.4 & $+3.5 / 4$ & 0 to +7.6 \\
\hline
\end{tabular}

The effective porosity and the unconfined storage coefficient were varied by \pm 50 percent, within the expected range of storage coefficients for basalt and sediment. Simulated water levels in layer 2 generally changed less than $5 \mathrm{ft}$ in response to these storage coefficient variations (fig. 14). Water levels in lower layers were slightly more sensitive to storage coefficient variations, perhaps because of smaller hydraulic conductivity values in those layers. No significant improvement or worsening of the match between measured and simulated water levels occurred except for cell 14-13-3, where the match slightly improved. On the basis of these results, the storage coefficient did not significantly affect perched water levels and the simulated extent of the perched ground-water zones.

\section{Discussion of Numerical Simulation Results and Model Limitations}

Until 1982, flow in much of the TRA perched ground-water zones was controlled by infiltration from the warm-waste ponds. In 1982, with the onset of discharge to the cold-waste ponds, the perched ground-water zones expanded to the southward and water levels in deeper perched wells rose substantially. Agreement between simulated and measured water levels indicates that these transient conditions were moderately to closely represented in layer 3 . Simulated water levels in layer 2 did not match well with measured water-level trends in monitoring wells completed in the $\mathrm{BC}$ flow group. The simulated extent of perched ground water approximated the known extent as determined from wells completed near the margins of the perched ground-water zones (fig. 15).

The capability of the transient simulation to reasonably match long-term measured waterlevel changes generally supported the conceptual model of perched ground-water flow. In several instances (wells 53,54, 55, and 56, all completed in the $\mathrm{BC}$ flow group near the warm-waste ponds), a poor matching of water-level trends provided a better understanding of the importance of the effects of fracture flow and the distribution of recharge on hydrologic conditions in the perched ground-water zones.

Perched ground-water zones at the TRA are characterized horizontally and vertically by large hydraulic gradients that are not completely simulated in the model. The water level in well PW-9, for example, was about $80 \mathrm{ft}$ lower than the water level in nearby well 73. Also, changes in the completion interval for well 72 increased the water level by about $60 \mathrm{ft}$. These large differences indicate that lateral perched zones are separated vertically in places by unsaturated conditions not represented in the model. Measured water levels in wells represented a composite water level over a completion interval that can include only a part of a basalt-flow group or can extend across two or more flow groups. The simulated water level in a specific cell matched the water level at the center of a volume of basalt and sediment simulated by that cell. Simulated water levels can differ from 

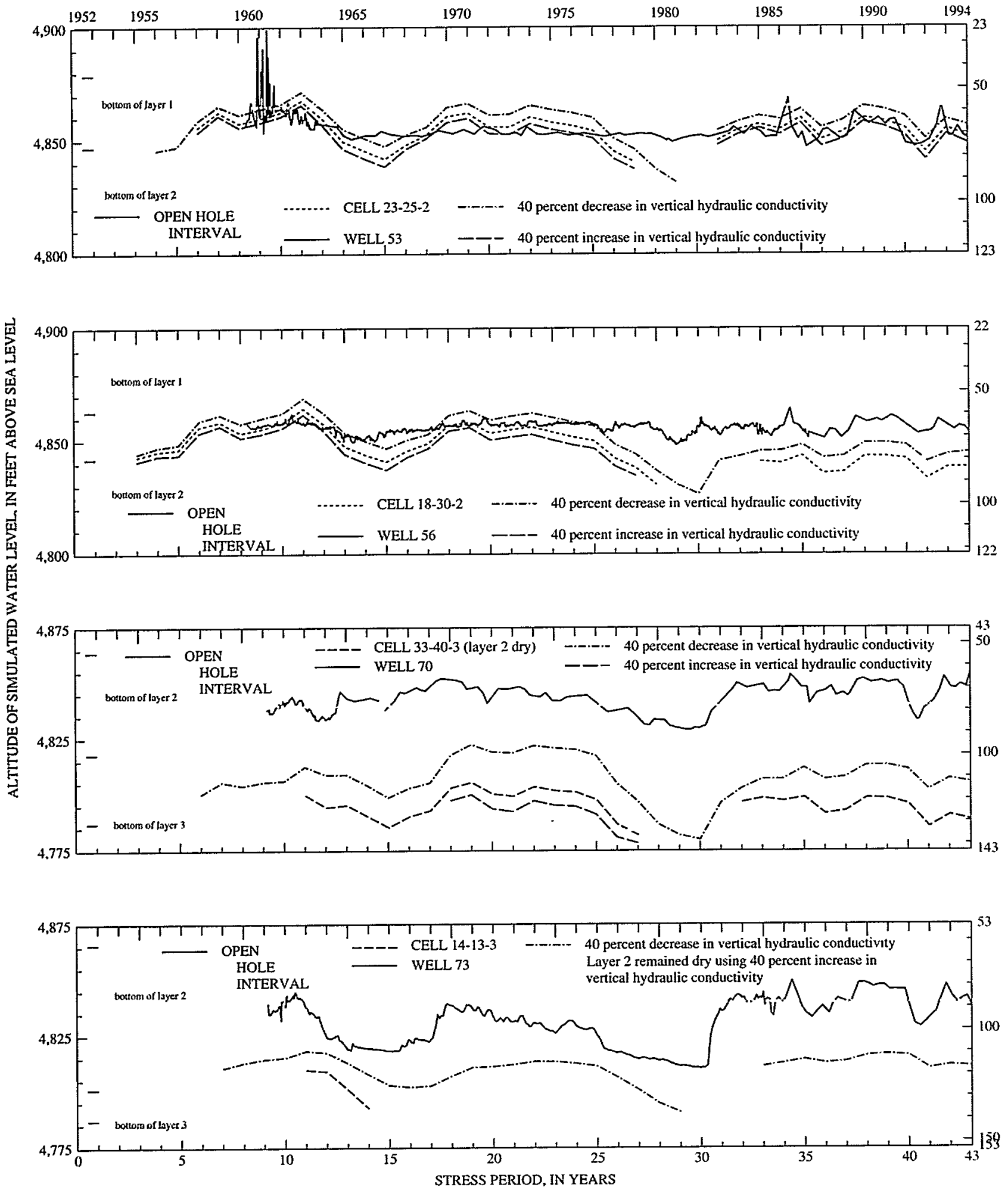

Figure 13. - Transient water levels at the Test Reactor Area simulated using \pm 40 -percent vertical hydraulic conductivity, 1952-94. 

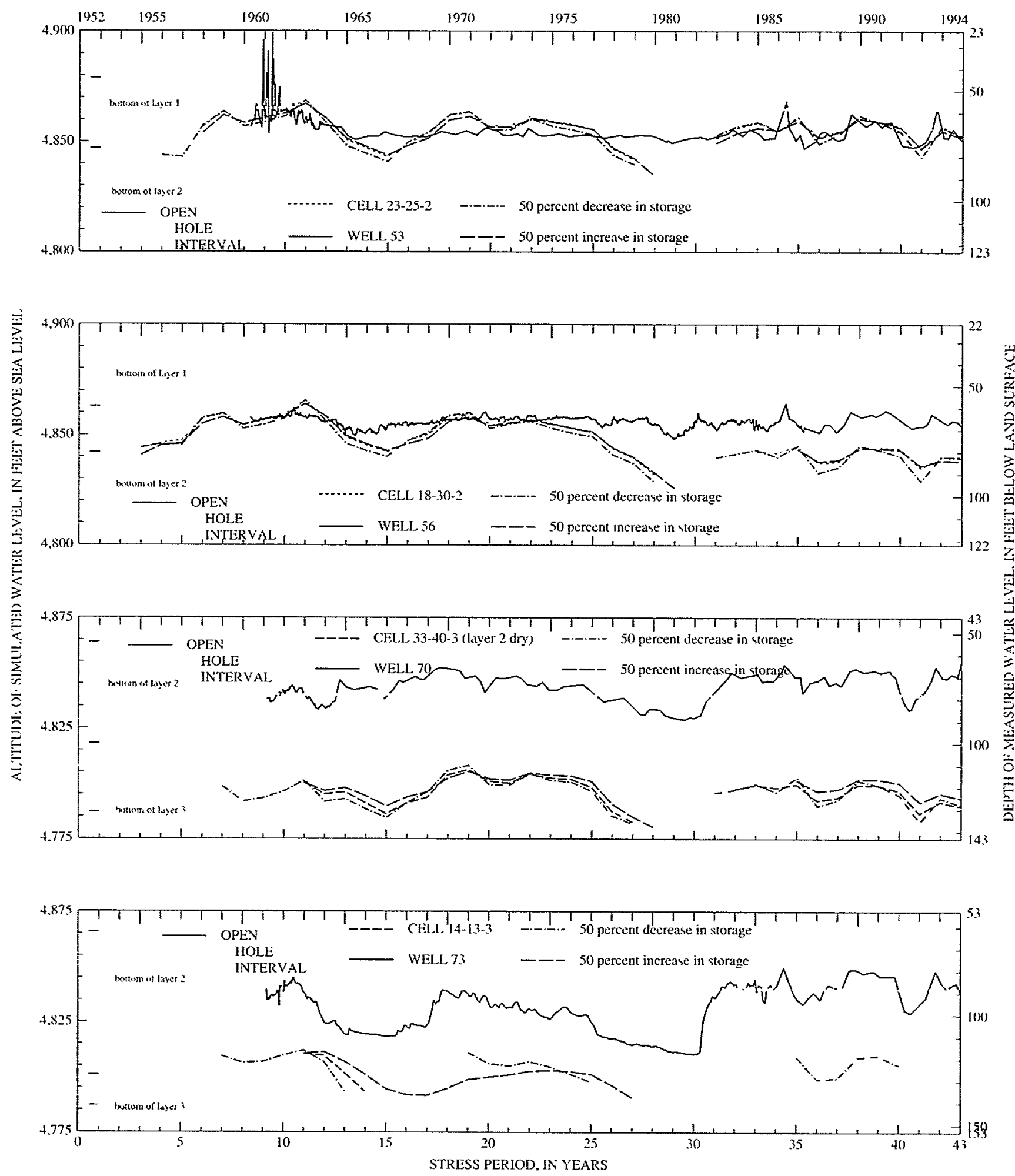

Figure 14. - Transient water levels at the Test Reactor Area simulated using \pm 50 -percent storage, 1952-94. 
measured water levels because a well might not be located in the center of a volume of basalt and sediment represented by a model cell.

The capability of basalt-flow groups at the TRA to store and transmit water is controlled largely by the anisotropic distribution and orientation of fractures. An accurate representation of the distribution of aquifer properties could not be simulated within the limits of the field data. However, by using a uniform hydraulic conductivity value within a layer, the model generally simulated long-term water-level trends moderately well. Locally, the actual distributions of these hydrologic properties can account for some differences between measured and simulated waterlevel trends.

Comparison of simulated water levels with measured water levels in wells completed in the $\mathrm{BC}$ flow group near the warm-waste and coldwaste ponds indicated that the actual hydraulic conductivity of the basalts in the $\mathrm{BC}$ flow group may exceed that assigned to model layer 2 . In cells close to wastewater recharge (23-25-2, well 53), simulated water-level trends were more responsive to simulated long-term recharge fluctuations than were measured water-level trends to actual changes in discharge.

Hydrologic data indicate that the northern part of the perched ground-water zones can be partially isolated hydraulically from the effects of warm-waste and cold-waste discharge. This isolation, attributed to fracture anisotropy and reduced hydraulic conductivity in basalt between the ponds and perched water to the north, is not represented in the model.

In some cells farther from sources of wastewater recharge (35-30-3, well 60), measured waterlevel changes were more responsive to long-term fluctuations in recharge than were simulated water-level changes. Again, this difference could be attributed to the anisotropic distribution of hydraulic properties related to fracture distribution. The unknown areal distribution and orientation of these fracture systems preclude a more accurate simulation of ground-water flow at the scale of individual wells used to monitor the TRA perched ground-water zones.
Since the early 1950's, discharge to the ponds has been characterized by large daily and monthly fluctuations. These short-term fluctuations have been reflected in corresponding measured water-level changes in nearby wells. In the transient model, recharge was simulated by an average annual recharge value; the effect of short-term fluctuations on water-level changes in perched water levels was not evaluated. Finer discretization of time and wastewater discharge will provide a more precise simulation of water-level changes in the perched ground-water zones.

Continued wastewater discharge to the warmwaste ponds plugged pond bottoms, decreasing wastewater infiltration in places and requiring construction of additional ponds. In the model, recharge was assumed to be distributed uniformly over the pond bottoms. The uniform distribution of simulated recharge did not accurately represent actual recharge and could have affected simulated water levels in cells close to recharge cells.

Other sources of recharge at the TRA included irrigation of landscaping and possible leakage from buried wastewater distribution systems. These sources were not simulated because they were difficult to quantify and were a relatively small percentage of total recharge. Although these sources of recharge probably do not have a significant hydraulic effect on the perched ground-water zones, they can affect local water levels and water chemistry.

Historically, streamflow was intermittent in the Big Lost River near the TRA, and was characterized by short-term flood peaks and corresponding fluctuations in streamflow infiltration. These fluctuations were reflected in ground-water level changes in several wells completed in the perched ground-water zones. In the model, recharge from streamflow was distributed uniformly over each 1-year stress period. Simulated recharge from streamflow infiltration was estimated based on the assumption that these losses were distributed uniformly along the river reach from the INEEL diversion to the Lincoln Boulevard bridge. Because the short-term recharge fluctuations were included in the annual average, the simulated perched ground-water zone beneath the Big Lost River did not form. A more precise simulation of the connection between the river and 


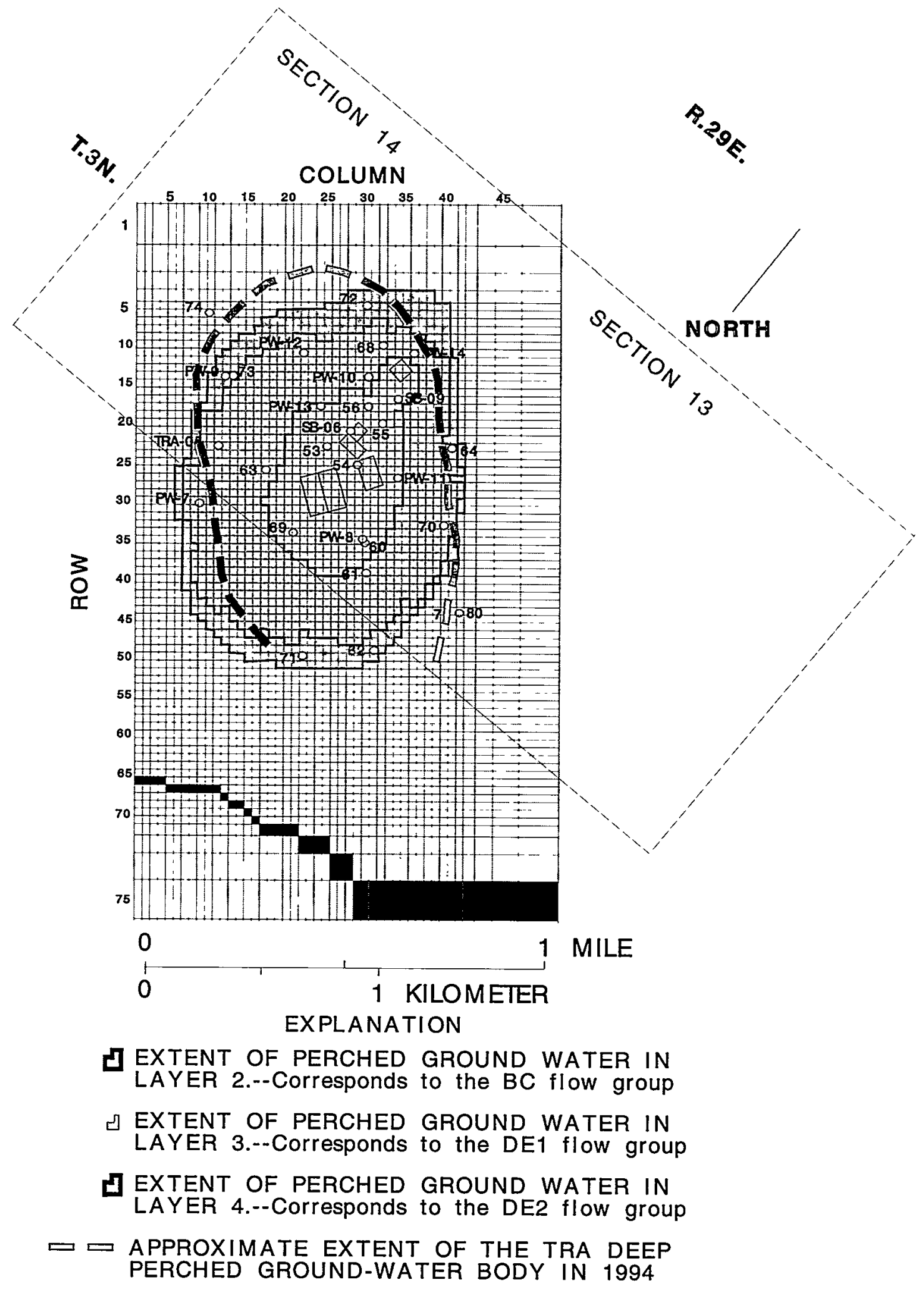

Figure 15.- Comparison between the extent of the known and simulated perched ground-water zones at the Test Reactor Area, December 1994. 
perched ground water beneath the TRA will require finer discretization of time and recharge from streamflow.

A transient simulation was run to evaluate the rate at which the perched ground-water zones would drain if all wastewater recharge and recharge from surface water ceased following stress period 43 (representing 1994 hydrologic conditions). At the end of stress period 43, a total of 344 layer- 2 cells (representing an area of about 79 acres), 1,161 layer- 3 cells (representing an area of about 266 acres), and 1,449 layer- 4 cells (representing an area of about 330 acres) contained some amount of water derived from wastewater recharge. All cells in layer 2 drained by the second timestep in stress period 44 (approximately 6 months). All cells in layer 3 drained by the end of the second timestep in stress period 47 (approximately 3.5 years). All cells in layer 4 drained by the end of the fourth timestep in stress period 47 (approximately 4 years).

The results of this transient simulation indicate that the $\mathrm{BC}$ and $\mathrm{DE} 1$ flow groups and the interbed unit will drain quickly in response to cessation of recharge from the TRA wastewater infiltration ponds. However, while saturated sediment in the interbed unit will drain partially, some water probably will be retained as capillary forces equal gravity flow.

\section{SUMMARY}

A sequence of perched ground-water zones in the unsaturated zone beneath wastewater infiltration ponds at the TRA provides an integral part of the pathway for wastewater from the TRA to move to the Snake River Plain aquifer. These perched ground-water zones have formed in and above zones of contrasting vertical hydraulic conductivity and are dependent upon the distribution of fractures and upon the vertical hydraulic conductivity and thickness of sedimentary interbeds.

A transient numerical simulation was used to evaluate the conceptual model of flow through perched ground-water zones at the TRA and to refine estimates of hydraulic properties that control the formation of these perched ground-water zones. The first layer represented surficial sediments, the second represented the BC basalt-flow group, the third represented the DE1 basalt-flow group, and the fourth represented the DE2, DE3, and DE3-4(W) basalt-flow groups. A fifth layer provided a constant-head boundary.

The numerical simulation required estimates of recharge derived from records of wastewaterdisposal and streamflow and estimates of hydraulic properties, including horizontal and vertical hydraulic conductivity, effective porosity, and the confined storage coefficient. Recharge was from wastewater disposal to warm-waste ponds, coldwaste ponds, a chemical-waste pond, and sanitary-waste ponds. Water-level changes in wells completed in the perched ground-water zones were related to changes in wastewater disposal. Transient recharge from wastewater infiltrationpond leakage was characterized by daily and monthly fluctuations in response to wastewater discharge patterns. Recharge from pond infiltration was represented in the numerical model by an average annual rate because records for the 43 years of wastewater discharge do not provide the detailed information needed to describe these short-term fluctuations. In the model, the wastewater recharge term was applied to the uppermost active cell. Annual recharge from the Big Lost River was estimated using discharge records from selected stream discharge gaging stations.

Hydraulic conductivity estimates for the BC flow group at the TRA ranged from 5 to 790 feet/day. An intermediate estimate probably provides a more realistic approximation of the average hydraulic conductivity of a block of basalt of the modeled cell dimensions. On the basis of calibration of the steady-state model, a hydraulic conductivity of 20 feet per day, within the range of estimated hydraulic conductivity for the BC flow group, was uniformly assigned to all cells in layer 2. Sensitivity analysis indicated that more precise simulation of water-level trends in the BC flow group will require a hydraulic conductivity more than 40 percent larger than the steady-state calibrated value.

The only hydraulic conductivity estimate available for saturated basalt in the DE1 flow group at the TRA was 0.11 feet per day. This flow group can be characterized by thicker sections of massive, unfractured basalt, with correspondingly smaller hydraulic conductivity than 
occurs in the $\mathrm{BC}$ flow group. On the basis of calibration of the steady-state model, a hydraulic conductivity of 2 feet per day was uniformly assigned to cells in layer 3 .

Model layer 4 was used to simulate flow within the interbed unit. These interbeds provide the contrasting vertical hydraulic conductivity required for the formation of perched groundwater zones. Hydraulic conductivity estimated from one short-term aquifer test in the interbed unit at the TRA was 2 feet per day. However, the DE2, DE3, and DE3-4(W) basalt-flow groups at the TRA typically contain as much as 90 percent sediment and probably are characterized by smaller hydraulic conductivity. On the basis of calibration of the steady-state model, a hydraulic conductivity of 0.01 foot per day was uniformly assigned to cells in layer 4 .

The vertical conductance terms used to represent flow between layers 2 and 3 and between layers 3 and 4 incorporated estimates of the vertical hydraulic conductivity and thickness of the basalts. Vertical conductance terms were assigned uniformly because little is known about the vertical hydraulic conductivity of the basalts except that it probably is at least several orders of magnitude smaller than the horizontal hydraulic conductivity. The calibrated vertical conductance term controlling flow between layers 2 and 3 was 0.0018 per day. The calibrated vertical conductance term controlling flow between layers 3 and 4 was 0.0006 per day.

The vertical conductance term used to simulate vertical flow through the interbed unit was based on the vertical hydraulic conductivity and the thickness of the sedimentary interbeds. This term was dominated by the vertical hydraulic conductivity of the interbeds because the capability of the interbeds to transmit water downward probably is several orders of magnitude smaller than that of the basalt. In the numerical simulation, the vertical conductance term was calculated by dividing an estimated vertical hydraulic conductivity by the interbed thickness. The calibrated value for vertical hydraulic conductivity was 0.0028 feet per day, within the range of estimated vertical hydraulic conductivity.
The unconfined storage coefficient for basalts in the BC and DE1 flow groups at the TRA reasonably ranges from 5 to 20 percent. Areally, the storage coefficient can vary over the full range because of variations in the number of vesicles, fractures, and interflow rubble zones. However, because distributions of these features are not well defined, storage coefficients were applied uniformly for each layer. An effective porosity of 10 percent, within the expected range of 5 to 20 percent, and a storage coefficient of 0.0001 were applied to all layers in the transient model calibration.

Simulated water levels were moderately sensitive to \pm 40 -percent variations in horizontal hydraulic conductivity. Decreased hydraulic conductivity increased transient simulated water levels by up to 10 feet. Simulated water levels generally were less sensitive to a 40-percent increase in hydraulic conductivity. Increased hydraulic conductivity decreased simulated water levels by 7 feet or less in most cells. The match between simulated water levels in layer 2 and water-level trends in wells close to warm-waste and cold-waste ponds was not improved by increasing hydraulic conductivity. Sensitivity analysis indicated that a hydraulic conductivity increase in excess of 40 percent for layer 2 would have been required to more precisely simulate hydrologic conditions in the $\mathrm{BC}$ flow group. The sensitivity of simulated water levels to these variations indicates that the distribution of horizontal hydraulic conductivity controls the size and shape of the perched ground-water zones at the TRA. A more precise simulation would require representation of the areal distribution of horizontal hydraulic conductivity instead of the uniform hydraulic conductivity used in this simulation.

Simulated water levels were moderately sensitive to \pm 40 -percent variations in the vertical conductance term. These variations were proportional to variations in vertical hydraulic conductivity within the range of vertical hydraulic conductivity estimated in a previous study. Simulated layer- 2 water levels generally were not sensitive to decreased or increased vertical hydraulic conductivity. Variations in vertical hydraulic conductivity generally changed water levels in layer 2 by less than 5 feet. Water levels 
in layers 3 and 4 in cells near the margins of the perched ground-water zones were more sensitive to changes in vertical hydraulic conductivity. Water levels increased as much as 19 feet in response to a 40-percent reduction in vertical hydraulic conductivity. A 40-percent increase decreased the size of the perched ground-water zones. The response of simulated water levels to changes in vertical hydraulic conductivity was less than the response to horizontal hydraulic conductivity. However, the effect of variations in vertical hydraulic conductivity can be significant, particularly in lower layers and near margins of saturation.

Simulated water levels were moderately sensitive to \pm 50 -percent variations in the unconfined storage coefficient. These variations were within the expected range of storage coefficients for basalt and sediment. Simulated water levels in layer 2 generally changed less than 5 feet in response to these storage coefficient variations. Water levels in lower layers were more sensitive to storage coefficient variations, perhaps because of smaller hydraulic conductivity values in those layers.

Comparison between simulated water levels and measured water levels indicated that transient water levels in layer 2 did not match directly to measured water-level trends in shallower monitoring wells completed in the $\mathrm{BC}$ flow group. Simulated water levels in layer 3 moderately to closely represented transient hydrologic conditions in the DE1 flow group. Water levels in layer 4 poorly matched measured water levels in the underlying interbed unit. The simulated extent of perched ground water approximated the known extent as determined from wells completed near the margins of the perched ground-water zones.

Simulated water levels can differ from measured water levels because perched ground-water zones at the TRA are characterized horizontally and vertically by large hydraulic gradients. The simulated water level in a specific cell matches the water level at the center of a volume of basalt and sediment delineated by that cell. In the horizontal dimension, a well might not be located in the center of an area represented by a model cell, and the measured water level might be different than the water level represented by the model. In the vertical dimension, the wells are completed over large intervals in a saturated section characterized by large gradients. Measured water levels represent a composite water level over an interval of completion that might include only a part of a basalt-flow group or extend across flow groups.

Locally large variations in horizontal hydraulic conductivity were ignored because of the difficulty in determining the spatial distribution of fractures and other features that control the flow of water. Except for the vertical conductance term used to simulate vertical flow through the sedimentary interbeds associated with the DE2, DE3, and DE3-4(W) basalt-flow groups, hydraulic properties were distributed uniformly within each layer. However, the model simulated long-term water-level trends moderately well using these uniformly distributed values. The actual heterogeneous distributions of these hydrologic properties can account for differences between measured and simulated water-level trends. These distributions can be attributed to multiple fracture systems with preferred orientations.

In the transient numerical flow model, recharge was simulated by a mean annual recharge value. The effect of short-term fluctuations on perched water levels was not evaluated. Finer discretization of time and wastewater discharge will provide a more precise simulation of water-level changes in the perched ground-water zones.

Recharge from streamflow infiltration in the Big Lost River at the TRA was estimated assuming that those losses were distributed uniformly along the river reach from the INEEL diversion to the Lincoln Boulevard bridge. This estimation ignored the fact that some estimated streamflow infiltration took place only in the upper reach and never affected the lower reach. Historically, streamflow also was characterized by intermittent flow, short-term flood peaks, and corresponding fluctuations in streamflow infiltration. In the model, recharge from streamflow was distributed uniformly over each year-long stress period. Because the short-term fluctuations were included in the annual average, the simulated perched ground-water zone beneath the Big Lost River did not form. More precise simulation of 
the connection between the river and perched ground-water zones will require finer discretization of time and recharge from streamflow.

A simulation was run to evaluate the effect of hypothetical cessation of recharge in 1994 . In this simulation, layer 2 drained in 6 months, layer 3 drained in 3.5 years, and layer 4 drained in 4 years. This simulation suggests that the $\mathrm{BC}$ and DE1 flow groups will drain quickly if recharge from the TRA wastewater infiltration ponds ceases; sediment associated with the DE2, DE3, and DE3-4(W) basalt-flow groups probably will drain quickly, but, in reality, some water will remain because of capillary forces.

Although the numerical model only approximated hydrologic conditions in the perched ground-water zones beneath the TRA, the model provided a reasonable simulation of the effect of transient recharge on these zones. More precise simulations will require a better understanding of the distribution and orientation of fractures and finer time discretization of wastewater and streamflow recharge.

\section{SELECTED REFERENCES}

Ackerman, D.J., 1991, Transmissivity of perched aquifers at the Idaho National Engineering Laboratory, Idaho: U.S. Geological Survey Water-Resources Investigations Report 914114 (DOE/ID-22099), 27 p.

-1995 , Analysis of steady-state flow and advective transport in the eastern Snake River Plain aquifer system, Idaho: U.S. Geological Survey Water-Resources Investigations Report 94-4257 (DOE/ID22120), 25 p.

Anderson, S.R., 1991, Stratigraphy of the unsaturated zone and uppermost part of the Snake River Plain aquifer at the Idaho Chemical Processing Plant and Test Reactors Area, Idaho National Engineering Laboratory, Idaho: U.S. Geological Survey Water-Resources Investigations Report 914010 (DOE/ID-22095), $71 \mathrm{p}$.
Barraclough, J.T., Teasdale, W.E., Robertson, J.B., and Jensen, R.G., 1967, Hydrology of the National Reactor Testing Station, Idaho, 1966: U.S. Geological Survey Open-File Report (IDO-22049), 95 p.

Barraclough, J.T., Lewis, B.D., and Jensen, R.G., 1981, Hydrologic conditions at the Idaho National Engineering Laboratory, Idaho, emphasis--1974-1978: U.S. Geological Survey Open-File Report 81-526 (IDO22060), $77 \mathrm{p}$.

Bartholomay, R.C., 1998, Distribution of selected radiochemical and chemical constituents in perched water, Idaho National Engineering Laboratory, Idaho, 1992-95: U.S.

Geological Survey Water-Resources Investigations Report 98-4026 (DOE/ID22145), $59 \mathrm{p}$.

Bartholomay, R.C., Knobel, L.L., and Davis, L.C., 1989, Mineralogy and grain size of surficial sediment from the Big Lost River drainage and vicinity, with chemical and physical characteristics of geologic materials from selected sites at the Idaho National Engineering Laboratory, Idaho: U.S. Geological Survey Open-File Report 89-384 (DOE/ID-22081), 74 p.

Bennett, C.M., 1990, Streamflow losses and ground-water level changes along the Big Lost River at the Idaho National Engineering Laboratory, Idaho: U.S. Geological Survey Water-Resources Investigations Report 90-4067 (DOE/ID22091), 49 p.

Bishop, C.W., 1991, Hydraulic properties of vesicular basalt: Tucson, University of Arizona, unpublished M.S. thesis, $115 \mathrm{p}$.

Cecil, L.D., Orr, B.R., Norton, Teddy, and Anderson, S.R., 1991, Formation of perched ground-water zones and concentrations of selected chemical constituents in water, Idaho National Engineering Laboratory, Idaho, 1986-88: U.S. Geological Survey Water-Resources Investigations Report 914166 (DOE/ID-22100), 53 p. 
Cecil, L.D., Pittman, J.R., Beasley, T.M., Michel, R.L., Kubik, P.W., Sharma, P., Fehn, U., and Gove, H.E., 1992, Water infiltration rates in the unsaturated zone at the Idaho National Engineering Laboratory estimated from chlorine-36 and tritium profiles, and neutron logging: in A.A. Balkema, ed., Proceedings of the 7th International Symposium on Water-Rock Interaction, Rotterdam/Brookfield, p. 709-715.

Freeze, R.A., and Cherry, J.A., 1979, Groundwater: Englewood Cliffs, N.J., Prentice-Hall, 604 p.

Garabedian, S.P., 1992, Hydrology and digital simulation of the regional aquifer system, eastern Snake River Plain, Idaho: U.S. Geological Survey Professional Paper 1408F, 102 p., 10 pls.

Hull, L.C., 1989, Conceptual model and description of the affected environment for the TRA warm waste pond (waste management unit TRA-03): EG\&G Idaho Informal Report EGG-ER-8644 [variously paged].

Knutson, C.F., McCormick, K.A., Crocker, J.C., Glenn, M.A., and Fishel, M.L., 1992, 3D RWMC vadose zone modeling (including FY-89 to FY-90 basalt characterization results): EG\&G Idaho, Inc., Report EGGERD-10246 [variously paged].

Knutson, C.F., McCormick, K.A., Smith, R.P., Hackett, W.R., O'Brien, J.P., and Crocker, J.C., 1990, FY-89 RWMC vadose zone basalt characterization: EG\&G Idaho, Inc. Report EGG-WM-8949 [variously paged].

Lewis, B.D., and Jensen, R.G., 1984, Hydrologic conditions at the Idaho National Engineering Laboratory, Idaho--1979-1981 update: U.S. Geological Survey Open-File Report 84-230 (IDO-22066), 65 p.

McDonald, M.G., and Harbaugh, A.W., 1988, A modular three-dimensional finite-difference ground-water flow model: U.S. Geological Survey Techniques of Water-Resources Investigations, book 6, chap. A1, $586 \mathrm{p}$.
McDonald, M.G., Harbaugh, A.W., Orr, B.R., and Ackerman, D.J., 1991, A method of converting no-flow cells to variable-head cells for the U.S. Geological Survey modular finite-difference ground-water flow model: U.S. Geological Survey Open-File Report 91-536, 99 p.

McElroy, Deborah, and Hubbell, Joel, 1990, Hydrologic and physical properties of sediments at the Radioactive Waste Management Complex, Idaho National Engineering Laboratory: EG\&G Idaho, Inc., Informal Report EGG-BG-9147, [variously paged].

Nace, R.L., Stewart, J.W., Walton, W.C., and others, 1959, Geography, geology, and water resources of the National Reactor Testing Station, Idaho-Part 3. Hydrology and water resources: U.S. Geological Survey OpenFile Report (IDO-22034-USGS), 253 p.

Naylor, P.N., 1988, Three-dimensional flow modeling of a perched water zone underlying waste disposal ponds at the Idaho National Engineering Laboratory: Provo, Brigham Young University, unpublished M.S. thesis [variously paged].

Pittman, J.R., Jensen, R.G., and Fischer, P.R., 1988, Hydrologic conditions at the Idaho National Engineering Laboratory, 1982 to 1985: U.S. Geological Survey WaterResources Investigations Report 89-4008 (DOE/ID-22078), 73 p.

Robertson, J.B., 1974, Digital modeling of radioactive and chemical waste transport in the Snake River Plain aquifer at the National Reactor Testing Station, Idaho: U.S. Geological Survey Open-File Report (IDO22054), $41 \mathrm{p}$.

-1977, Numerical modeling of subsurface radioactive solute transport from wasteseepage ponds at the Idaho National Engineering Laboratory: U.S. Geological Survey Open-File Report 76-717 (ID022057), 68 p. 
Robertson, J.B., Schoen, Robert, and Barraclough, J.T., 1974, The influence of liquid waste disposal on the geochemistry of water at the National Reactor Testing Station, Idaho: U.S. Geological Survey Open-File Report (IDO-22053), 231 p.

Spinazola, J.M., 1994, Geohydrology and simulation of flow and water levels in the aquifer system in the Mud Lake area of the eastern Snake River Plain, eastern Idaho: U.S. Geological Survey Water-Resources Investigations Report 93-4227, 78 p.
Todd, D.K., 1980, Groundwater hydrology, 2d ed.: John Wiley \& Sons, 535 p.

Tucker, B.J., and Orr, B.R., 1998, Distribution of selected radiochemical and chemical constituents in perched water, Idaho National Engineering Laboratory, Idaho, 1989-91: U.S. Geological Survey WaterResources Investigations Report 98-4028 (DOE/ID-22144), 62 p. 